\title{
Purinergic signalling in the musculoskeletal system
}

\author{
Geoffrey Burnstock • Timothy R. Arnett • Isabel R. Orriss
}

Received: 8 July 2013 / Accepted: 12 July 2013 / Published online: 14 August 2013

(C) Springer Science+Business Media Dordrecht 2013

\begin{abstract}
It is now widely recognised that extracellular nucleotides, signalling via purinergic receptors, participate in numerous biological processes in most tissues. It has become evident that extracellular nucleotides have significant regulatory effects in the musculoskeletal system. In early development, ATP released from motor nerves along with acetylcholine acts as a cotransmitter in neuromuscular transmission; in mature animals, ATP functions as a neuromodulator. Purinergic receptors expressed by skeletal muscle and satellite cells play important pathophysiological roles in their development or repair. In many cell types, expression of purinergic receptors is often dependent on differentiation. For example, sequential expression of $\mathrm{P} 2 \mathrm{X} 5, \mathrm{P} 2 \mathrm{Y}_{1}$ and $\mathrm{P} 2 \mathrm{X} 2$ receptors occurs during muscle regeneration in the $m d x$ model of muscular dystrophy. In bone and cartilage cells, the functional effects of purinergic signalling appear to be largely negative. ATP stimulates the formation and activation of osteoclasts, the bone-destroying cells. Another role appears to be as a potent local inhibitor of mineralisation. In osteoblasts, the bone-forming cells, ATP acts via P2 receptors to limit bone mineralisation by inhibiting alkaline phosphatase expression and activity. Extracellular ATP additionally exerts significant effects on mineralisation via its hydrolysis product, pyrophosphate. Evidence now suggests that purinergic signalling is potentially important in several bone and joint disorders including osteoporosis, rheumatoid arthritis and cancers. Strategies for future musculoskeletal therapies might involve modulation
\end{abstract}

\section{G. Burnstock}

Autonomic Neuroscience Centre, University College Medical

School, Rowland Hill Street, London NW3 2PF, UK

G. Burnstock $(\bowtie)$

Department of Pharmacology, The University of Melbourne,

Melbourne, Australia

e-mail: g.burnstock@ucl.ac.uk

T. R. Arnett $\cdot$ I. R. Orriss

Department of Cell \& Developmental Biology, University College

London, Gower Street, London WC1E 6BT, UK of purinergic receptor function or of the ecto-nucleotidases responsible for ATP breakdown or ATP transport inhibitors.

Keywords Bone $\cdot$ Cartilage $\cdot$ Joints $\cdot$ Arthritis $\cdot$ Muscular dystrophy $\cdot$ Cancer

\section{Synopsis}

Introduction

\section{Skeletal muscle}

Skeletal neuromuscular junction

Skeletal muscle

\section{Bone}

Osteoblasts

$P 2$ receptor expression by osteoblasts

Functional effects of $P 2$ receptor-mediated signalling in osteoblasts

ATP release from osteoblasts

ATP hydrolysis and the effects on bone mineralisation

$P 1$ receptors, adenosine and osteoblasts

Osteocytes

Osteoclasts

$P 2$ receptor expression by osteoclasts

Functional effects of $P 2$ receptor-mediated signalling in osteoclasts

P1 receptors, adenosine and osteoclasts

Bone marrow stromal cells or mesenchymal stem cells

\section{Cartilage and chondrocytes}

P2 Receptor expression by chondrocytes

Functional effects of $\mathrm{P} 2$ receptor-mediated signalling in chondrocytes

ATP release and breakdown in cartilage

$\mathrm{P} 1$ receptors, adenosine and chondrocytes 


\section{Ligaments and tendons}

Ligaments

Tendons

\section{Diseases of the musculoskeletal system}

\author{
Skeletal muscle diseases \\ Muscular dystrophy \\ Myasthenia gravis \\ Fibromyalgia
}

Bone and joint disorders

Osteoporosis
Periodontitis

Paget's disease

Rickets

Ossification of the posterior longitudinal ligament of

the spine (OPLL)

Rheumatoid arthritis

Osteoarthritis

Bone cancer and multiple myeloma

Severe combined immunodeficiency (SCID)

Desbuquois dysplasia

Dwarfism (achondroplasia)

\section{Concluding remarks}

\section{Introduction}

A physiological role for ATP at the skeletal neuromuscular junction was recognised early. Injection of ATP into the sciatic artery supplying the gastrocnemius muscle of the frog produced tetanus-like contractions [1]. They also reported that the sensitivity of the preparation to acetylcholine (ACh) was greatly increased by previous application of ATP [2]. ATP was later shown to be released together with ACh from cholinergic nerves in various tissues, including the electric organ of elasmobranch fish $[3,4]$ and phrenic nerve endings in the rat diaphragm $[5,6]$. However, it was not recognised at the time as a cotransmitter, but was considered as a molecule involved in the vesicular uptake and storage of the neurotransmitter ACh.

Investigations concerned with purinergic signalling in bone did not begin until the late 1980s. Initial studies demonstrated that extracellular nucleotides could induce increases in intracellular $\mathrm{Ca}^{2+}$ in bone cells [7-10]. Later, it was shown that extracellular ATP could inhibit bone formation whilst promoting bone resorption $[11,12]$. There is now abundant evidence to show that extracellular nucleotides play a key role in modulating the differentiation, function and survival of bone cells.

In this article, we review in depth the role of purinergic signalling in mature and developing skeletal muscle, bone and cartilage in health and disease

\section{Skeletal muscle}

Skeletal neuromuscular junction

To date, much of the evidence for purinergic involvement in skeletal neuromuscular transmission has come from studies of the fish electric organ, frog and chick neuromuscular junctions (see [13] and [14-21]).

In early studies, ATP and adenosine were shown to inhibit the release of ACh from motor nerve terminals [22, 23]. The effect of ATP was due to adenosine, produced after ATP breakdown, acting on presynaptic $A_{1}$ receptors [24-28]. ATP also acted postsynaptically to facilitate the action of ACh [29]. In the early development of the neuromuscular junction, released ATP can act on P2X receptor ion channels as a genuine cotransmitter along with $\mathrm{ACh}$ acting on nicotinic receptors. However, in mature animals, ATP acts as a modulator at both pre-junctional and post-junctional sites, rather than as a cotransmitter [23, 30-34] (Fig. 1). It was also demonstrated that ACh and ATP were both released by exocytosis from synaptic vesicles $[35,36]$ and there was a highaffinity adenosine uptake system in synaptosomes for reconstitution of stored ATP. Excitatory adenosine $\mathrm{A}_{2 \mathrm{~A}}$ receptors also coexist with inhibitory $\left(A_{1}\right)$ receptors at the rat and mouse neuromuscular junction [37-40].

P2X7-like receptors are expressed in the mouse neuromuscular junction [41] and activation of these receptors results in release of synaptic vesicles [42]. ATP, acting via P2Y receptors, was shown to inhibit non-quantal ACh release at the neuromuscular junction of mouse [43, 44]. Later, it was identified that activation of the $\mathrm{P} 2 \mathrm{Y}_{12}$ and $\mathrm{P} 2 \mathrm{Y}_{13}$ receptors, as well as adenosine $A_{1}$ receptors, inhibited $A C h$ release from mammalian motor nerve terminals [45]. The role of P2Y receptors

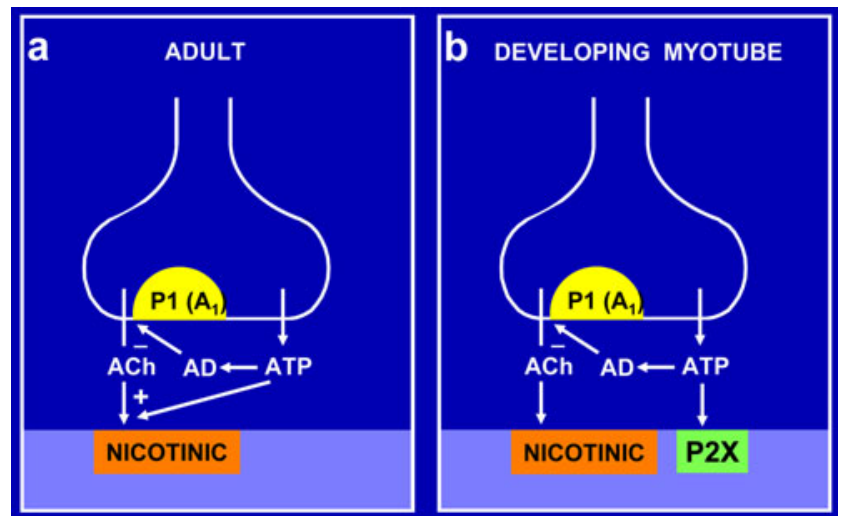

Fig. 1 a In the adult skeletal neuromuscular junction, acetylcholine (ACh) is the neurotransmitter acting on postsynaptic nicotinic receptors. ATP is released during neurotransmission and, after breakdown to adenosine, acts on presynaptic $\mathrm{P} 1\left(\mathrm{~A}_{1}\right)$ receptors to inhibit release of $\mathrm{ACh}$. b In the developing myotube, ATP is a genuine cotransmitter together with ACh acting on postsynaptic P2X receptors. (Reproduced from [13] with permission from Springer) 
in ATP-mediated regulation of non-quantal ACh release from motor nerve endings in the rat diaphragm has recently been reviewed in detail [46]. A study detailing the reversal effect of NF449, an analogue of suramin, on neuromuscular blockade induced by d-tubocurarine has been published [47]. ATP co-released with ACh from motor nerve terminals may also play a role in the regulation of the cell volume of muscle fibres [48].

During development, expression of $\mathrm{P} 2 \mathrm{X} 2$ receptors coincides with the appearance and formation of neuromuscular junctions [49]. This receptor interacts with nicotinic ACh receptors to produce cross-inhibition of channel opening [50]. Using the P2X2 receptor knockout mouse, it was shown that in the absence of $\mathrm{P} 2 \mathrm{X} 2$ receptors, the post-junctional synaptic folds rich in nicotinic receptors were disorganized; there was also misapposition of pre-synaptic terminals and regions of high localization of nicotinic receptors [51]. Furthermore, there was decreased density of post-synaptic junctional folds and increased end-plate fragmentation. ATP promotes stabilization of the neuromuscular junction and may play a role in activity-dependent synaptic modifications during development [52].

Sensory fibres originating in the dorsal root ganglia (DRG) supply skeletal muscle, and it was concluded that P2X5 and/or P2X4 receptors in combination with proton-activated channels and transient receptor potential cation channels are used to detect metabolites produced by contracting muscles [53]. The exercise pressor reflex is evoked by contraction and it was proposed that $\mathrm{P} 2 \mathrm{X} 3$ and $\mathrm{P} 2 \mathrm{X} 2 / 3$ receptors on muscle afferents mediate this reflex [54].

\section{Skeletal muscle}

In the early 1980s, extracellular ATP was shown to act on skeletal muscle cells when it was suggested that cultured myoblasts and myotubes may have ATP-sensitive cation channels [30]. It was shown that when the ATP analogue adenyl-5'-yl imidodiphosphate was added to muscle fibres in rigor, it caused the fibre to lengthen, but not apparently by acting at the contractile actin myofilament level (see [55]). The source of ATP can be as a cotransmitter released from motor nerves or it can be released from stressed or exercising muscle, as well as damaged or dying cells and vascular endothelial cells [56-58]. Extracellular ATP, acting via P2 receptors, was later shown to induce inositol 1,4,5-trisphosphate $\left(\mathrm{InsP}_{3}\right)$ accumulation before or after fusing rat skeletal muscle cells in culture, but not during the period of fusion [59]. Nucleotide diphosphates also activated ATP-sensitive potassium channels in mouse skeletal muscle [60]. Two types of human $\mathrm{P}_{2} \mathrm{Y}_{1}$ cDNA clones were isolated from the human erythro leukaemia cell cDNA library. A multiple human tissue Northern blot indicated two transcripts of approximately 4.4 and $7.0 \mathrm{~kb}$ and the mRNA for both transcripts were expressed in skeletal muscle [61].

A P2X receptor gene, regulated by p53, was shown to be expressed predominantly on skeletal muscle and it was suggested that the receptors may play a role in the proliferation and/or differentiation of skeletal muscle [62]. In addition, it was also suggested that altered expression may be involved in the development of some sarcomas [62]. Novel P2X receptors were also described on chick embryos [63, 64], although it was later shown to be homologous to the P2X5 receptor isoform [65]. In cultures of human skeletal muscle fibres, ATP was shown to elevate intracellular $\mathrm{Ca}^{2+}\left(\left[\mathrm{Ca}^{2+}\right]_{\mathrm{i}}\right)[66]$. The response to $\alpha, \beta$-methylene ATP $(\alpha, \beta$-meATP) was greater than ATP, suggesting that the effects were mediated by a $\mathrm{P} 2 \mathrm{X} 1$ and/or P2X3 receptors.

The pattern of purinergic receptor expression in skeletal muscle varies with the developmental stage and species. Sequential expression of $\mathrm{P} 2 \mathrm{X} 2, \mathrm{P} 2 \mathrm{X} 5$ and $\mathrm{P} 2 \mathrm{X} 6$ receptors has been described for developing rat skeletal muscle [49], while $\mathrm{P} 2 \mathrm{X} 1, \mathrm{P} 2 \mathrm{X} 4, \mathrm{P} 2 \mathrm{X} 5$ and P2X6 receptors have been demonstrated in developing chicken myoblasts $[65,67,68]$. One study suggested that P2X4 receptors are localised intracellularly on T-tubule membranes, suggesting that they may play a role in excitation-contraction coupling [69]. Thus, P2X receptors play important roles in the early development of skeletal muscle, but immediately after birth, the expression levels of P2X receptors are reduced and often functionally undetectable [67, 70]. Low levels of P2X7 receptors were detected in human skeletal muscle [71]. ATP also regulates the differentiation of mammalian skeletal muscle by activation of P2X 5 receptors on satellite cells [72]. P2X4, P2X5, P2X7, $\mathrm{P}_{2} \mathrm{Y}_{1}$ and $\mathrm{P}_{2} \mathrm{Y}_{4}$ receptors have also been demonstrated on multinucleated mouse myoblasts [73].

A number of studies have also implicated $\mathrm{P} 2 \mathrm{Y}$ receptors in skeletal muscle development. P2Y receptors were described on developing $\mathrm{C} 2 \mathrm{C} 12$ mouse myotubes [74] and on embryonic skeletal muscle [75]. $\mathrm{P} 2 \mathrm{Y}_{1}, \mathrm{P}_{2} \mathrm{Y}_{2}$ and $\mathrm{P}_{2} \mathrm{Y}_{4}$ receptors were shown to be only temporarily expressed in embryos and were down-regulated in postnatal life. Differentiating skeletal muscle $\mathrm{C} 2 \mathrm{C} 12$ cells express $\mathrm{P}_{2} \mathrm{Y}_{1}, \mathrm{P}_{2} \mathrm{Y}_{2}, \mathrm{P}_{2} \mathrm{Y}_{4}$ and $\mathrm{P} 2 \mathrm{Y}_{6}$ receptor mRNA [70]. At the transcriptional level, $\mathrm{P}_{2} \mathrm{Y}_{1}$ and $\mathrm{P}_{2} \mathrm{Y}_{2}$ receptors have been identified in human skeletal muscle $[76,77]$ and ATP stimulates an increase in $\left[\mathrm{Ca}^{2+}\right]_{\mathrm{i}}$ in human myotubes [78]. 5'-Guanosine-triphosphate (GTP) has also been shown to play a role in the early phases of skeletal muscle differentiation [79]. However, whilst purinoceptors clearly play significant roles during the development of skeletal muscle, differentiated muscle fibres barely express them, but after denervation they reappear [14]. The role of purinergic signalling during the formation of skeletal muscle myotubes has also been comprehensively examined [80].

A number of studies have investigated the intracellular signalling pathways activated following stimulation of P2 
receptors on skeletal muscle. Treatment with ATP significantly increased the strength of mouse diaphragm muscle contractions induced by carbachol and suramin abolished this effect, as did the specific protein kinase $\mathrm{C}$ (PKC) inhibitor, chelerythrine [81]. Differentiation of skeletal muscle cells both in vivo and in vitro is accompanied by the development of alterations of voltage-dependent processes and alterations in purinergic signalling [82]. Overexpression of PKC $\alpha$ demonstrated the appearance of increases in $\left[\mathrm{Ca}^{2+}\right]_{\mathrm{i}}$ elicited by ATP, but failed to do so after depolarising stimuli. PKC $\alpha$ over-expression changed the purinergic receptor pattern of immature myoblasts; there was lack of increase in the expression of $\mathrm{P} 2 \mathrm{X} 7$ receptors and failure of $\mathrm{P}_{2} \mathrm{Y}_{4}$ receptors to appear and $\mathrm{P} 2 \mathrm{Y}_{2}$ receptors to disappear. Uridine 5 '-triphosphate (UTP) produced InsP $_{3}$-dependent $\mathrm{Ca}^{2+}$ release in cultured myotubes [83], but UTP had little effect on adult muscles [84].

$\mathrm{Ca}^{2+}$ influx into $\mathrm{C} 2 \mathrm{C} 12$ cells via $\mathrm{P} 2 \mathrm{X}$ receptors contributes to phosphorylation of extracellular signal-regulated protein kinase 1/2 (ERK1/2) [70]. In differentiated human skeletal muscle cells, ATP evoked a $\mathrm{Ca}^{2+}$ transient, which was mediated by $\mathrm{P} 2 \mathrm{Y}$ receptors leading to the activation of ERK1/2. This suggests that extracellular ATP participates in skeletal muscle plasticity and highlights the importance of ATP as a cotransmitter at the neuromuscular junction via dual signalling, causing $\mathrm{InsP}_{3}$ receptor-mediated $\mathrm{Ca}^{2+}$ transients and $\mathrm{Ca}^{2+}$ insensitive phosphorylation of ERK1/2 [85].

The $\mathrm{P} 2 \mathrm{Y}_{1}$ receptor is emerging as having an important role in skeletal muscle function. Extracellular nucleotides, acting via the $\mathrm{P}_{2} \mathrm{Y}_{1}$ receptor, enhance muscle contraction by increasing the expression of ACh receptors and the activity of cholinesterase [86]. Activation of this receptor by ATP also inhibits $\mathrm{Cl}^{-}$channels in mature mammalian skeletal muscle; this has implications for muscle excitability and fatigue and the pathophysiology of myotonias [87]. Upregulation of $\mathrm{Na}, \mathrm{K}-$ ATPase activity during muscle activity appears to be due to the stimulatory effect of adenosine 5'-diphosphate (ADP) acting via $\mathrm{P}_{2} \mathrm{Y}_{13}$ receptors with some contribution from $\mathrm{P} 2 \mathrm{Y}_{1}$ receptors [88]. The signalling via $\mathrm{P} 2 \mathrm{Y}_{1}$ receptors to increase the $\mathrm{Na}^{+}-\mathrm{K}^{+}$pump activity improves the force and excitability of depolarised skeletal muscle, which may be important for the maintenance of excitability during intense exercise [89]. Supplementation with ATP for 15 days was reported to reduce muscle fatigue at the end of an exhaustive exercise bout [90].

ATP is released from skeletal muscle during titanic contraction [56, 69] and high-frequency electrical stimulation leads to fatigue involving extracellular $\mathrm{Ca}^{2+}$; however, it was claimed that P2X receptor antagonists did not affect the development of high-frequency fatigue [91]. ATP is released by electrical stimulation of skeletal muscle, probably through pannexin hemichannels $[92,93]$, eliciting both a fast calcium signal associated with contraction via $\mathrm{P} 2 \mathrm{X}$ receptors and a slow signal that regulates gene expression via $\mathrm{P} 2 \mathrm{Y}$ receptors
[56] and triggers interleukin (IL)-6 expression [94]. ATP is also released from skeletal muscle by mechanical stimulation (compression) [95].

ATP, released by autocrine/paracrine mechanisms, also regulates proliferation of $\mathrm{C} 2 \mathrm{C} 12$ myoblasts [96]. A recent paper demonstrated that extracellular ATP controls mouse myoblast proliferation via induction of reactive oxygen species [97]. Activation of $\mathrm{P} 2 \mathrm{X}$ receptors on skeletal muscle appears to play a role in mediating the exercise pressor reflex [98]; later, it was suggested that the ATP that triggered this reflex was released from contracting muscle [99] or endothelial cells [57].

Cytoplasmic $\mathrm{Ca}^{2+}$ concentration and $\mathrm{Ca}^{2+}$ handling molecular machinery tightly regulate skeletal muscle contraction and excitation of skeletal muscle results in rapid $\mathrm{Ca}^{2+}$ release from sarcoplasmic reticulum through the ryanodine receptor channel type 1 (RyR1). Nucleotides activate skeletal muscle ryanodine receptors, whilst adenosine inhibits the ATP activation of these receptors [100]. In addition, a P2 receptor antagonist, the suramin analogue, NF676, inhibits the RyR1 receptor [101]. The ATP binding characteristics of RyR1 are modulated by a variety of pharmacological agents, and it was speculated that modulation of ATP binding may play a central role in the regulation of the open/closed state of the channel [102]. It is now apparent that the transient component of calcium flux depends on activation of $\mathrm{P} 2 \mathrm{X}$ receptors and the consequent depolarisation, whereas $\mathrm{P} 2 \mathrm{Y}$ receptors are responsible for most of the maintained calcium flux [103].

The synthesis of extracellular ATP was found to be increased with a high level of adenylate kinase 1 (AK1) and ATP synthase $\beta$ during C2C12 myogenesis [104]. Experiments with AK1 knock-down led to the conclusion that AK1 secretion is required for ATP generation in myotubes. Extracellular ATP increased L-carnitine transport and content in $\mathrm{C} 2 \mathrm{C} 12$ cells; specific inhibitors of $\mathrm{P} 2 \mathrm{X}$ and $\mathrm{P} 2 \mathrm{Y}$ receptors abolished this effect [105].

In terms of $\mathrm{P} 1$ receptor signalling, a dramatic increase in expression of $\mathrm{A}_{2 \mathrm{~B}}$ and $\mathrm{A}_{3}$ (but not $\mathrm{A}_{1}$ or $\mathrm{A}_{2 \mathrm{~A}}$ ) receptors was observed following traumatic skeletal muscle injury. Thus, it was suggested that both receptors may be potential targets for stimulation of skeletal muscle regeneration and functional restoration after injury [106]. In addition, a protective role for adenosine, acting via $\mathrm{A}_{3}$ receptors, was identified for the treatment of post-traumatic skeletal muscle injury [107].

\section{Bone}

Within the skeleton, osteoblasts are the cells responsible for bone formation, whilst osteoclasts control bone resorption. A balance between osteoblastic bone formation and osteoclastic resorption is essential for a functional skeleton. In vivo mechanical loading can induce new bone formation and 
increase bone mineral density, whereas disease, immobilization and weightlessness can all lead to bone loss. Osteocytes, which are the most abundant cell type in bone, form an interconnecting network concerned with sensing mechanical load. Chondrocytes are the cells responsible for cartilage formation.

It was recognised in the 1990s that ATP released from damaged cells or by physiological secretion in response to mechanical stress could be an important factor in the remodelling of bone [108, 109]. Since these early investigations, understanding about the regulation of bone cell function by purinergic signalling has increased considerably.

Many studies have demonstrated the expression of multiple $\mathrm{P} 2 \mathrm{X}$ and $\mathrm{P} 2 \mathrm{Y}$ receptor subtypes in osteoclasts, osteoblasts and chondrocytes from a number of species, including rat, mouse, rabbit and human (see reviews [110-113]). Analysis of P2 $\mathrm{Y}_{1}$, $\mathrm{P}_{2} \mathrm{Y}_{2}, \mathrm{P}_{2} \mathrm{Y}_{6}, \mathrm{P} 2 \mathrm{Y}_{12}, \mathrm{P} 2 \mathrm{Y}_{13}$ and $\mathrm{P} 2 \mathrm{X} 7$ knockout mice has provided evidence for the important role of purinergic signalling in bone remodelling in vivo [115-122]. Previous reviews concerned with purinergic signalling on bone have focussed on different aspects, including bone marrow cells [123]; bisphosphonates [124-126]; osteoblasts and osteoclasts [113, 127-129]; bone remodelling [110, 130-132]; osteoblasts and antiresorptive drugs [133-135]; P2X7 receptors [136-139]; neuroskeletal signalling pathways [140]; exercise and mechanical loading of bone [141]; calcium signalling in bone [142]; adenosine in inflammatory joint diseases [143]; P2 receptor knockout mice and bone phenotypes [118]; ion channels and transporters in osteoclasts [144]; platelets and bone reconstruction therapy [145]; bone mineralisation [146]; acidosis and hypoxia [147]; and adenosine receptors in rheumatoid arthritis (RA) [148].

\section{Osteoblasts}

\section{P2 receptor expression by osteoblasts}

The first description of purinergic signalling in osteoblasts was in the late 1980s when $\mathrm{P} 1\left(\mathrm{~A}_{2}\right.$-like $)$ adenosine receptors were reported on osteoblasts $[149,150]$. Increases in $\left[\mathrm{Ca}^{2+}\right]_{\mathrm{i}}$ of osteoblasts in response to ATP and UTP were later described [7-9, 109], indicating the presence of more than one subtype of $\mathrm{P} 2 \mathrm{Y}$ receptor [151-155].

$\mathrm{P} 2 \mathrm{U}$ (i.e. $\mathrm{P} 2 \mathrm{Y}_{2}$ and/or $\mathrm{P}_{2} \mathrm{Y}_{4}$ ) receptors were cloned from human osteoblasts in the 1990s [156]. In single cell studies of human osteoblasts, different populations responded predominantly to ADP, others to ATP or UTP; this was suggested to reflect variations in the differentiation status of individual cells [157]. This idea was confirmed by a later study, which demonstrated that osteoblastic expression of $\mathrm{P} 2$ receptors was strongly dependent on cellular differentiation [158]. A higher expression of $\mathrm{P}_{2} \mathrm{Y}_{2}$ receptors was also found in differentiated compared to undifferentiated MC3T3-E1 osteoblasts [159].
Furthermore, it was recently shown that the P2Y receptormediated increase in $\left[\mathrm{Ca}^{2+}\right]_{\mathrm{i}}$ from the osteoblastic TBR31-2 cell line differs with time in culture and is associated with the level of expression of $\mathrm{P} 2 \mathrm{Y}$ receptors [160].

A number of studies have now demonstrated the expression of $\mathrm{P} 2 \mathrm{Y}_{1}, \mathrm{P} 2 \mathrm{Y}_{2}, \mathrm{P}_{2} \mathrm{Y}_{4}$ and $\mathrm{P} 2 \mathrm{Y}_{6}$ receptor mRNA and protein in several human osteoblast-like cell lines (MG-63, OHS-4, SaM-1, SaOS-2, Te85) $[156,161,162]$ and the rat osteosarcoma cell line, UMR106-01 [163, 164]. Of the several P2Y receptors expressed by the UMR106-01 cell line, the $\mathrm{P} 2 \mathrm{Y}_{1}$ receptor is thought to be predominant [163]. In contrast, another rat osteosarcoma cell line ROS17/2.8 does not appear to express functional $\mathrm{P}_{2} \mathrm{Y}_{2}$ receptors [164]. Functional $\mathrm{P} 2 \mathrm{Y}$ receptors, particularly the $\mathrm{P}_{2} \mathrm{Y}_{1}$ subtype, were also shown to be expressed by human G292 osteoblastic cells [165]. Primary rat calvarial osteoblasts were initially shown to express mRNA and protein for the $\mathrm{P}_{2} \mathrm{Y}_{1}, \mathrm{P}_{2} \mathrm{Y}_{2}, \mathrm{P}_{2} \mathrm{Y}_{4}$ and $\mathrm{P} 2 \mathrm{Y}_{6}$ receptors $[158,166]$. Later studies also reported the expression of the $\mathrm{P} 2 \mathrm{Y}_{12}, \mathrm{P}_{2} \mathrm{Y}_{13}$ and $\mathrm{P} 2 \mathrm{Y}_{14}$ receptors in this model $[167,168]$.

Widespread expression of P2X receptors on osteoblasts has also been reported. Initial studies on cultured rat osteoblasts identified the expression of the P2X2 and P2X5 receptor subtypes [166]. Follow-up studies by the same group also demonstrated the expression of mRNA and protein for the P2X1, P2X3, P2X4 and P2X6 receptor, although there were changes in expression during differentiation [158, 167]. This study also demonstrated large variations in the relative expression of the P2 receptors in osteoblasts, with mRNA for the P2X4 receptor being the most abundant [167]. Expression of the $\mathrm{P} 2 \mathrm{X} 7$ receptor was first demonstrated in a subpopulation of human differentiated osteoblasts [169]; later studies also demonstrated expression in rat $[158,167]$ and mouse osteoblasts [137]. Interestingly, a recent study claimed that P2X7 receptors are localised in caveolae in the plasma membranes of osteoblasts [170]. Expression of multiple P2X receptor subtypes has also been shown on several human osteoblastlike cell lines (MG-63, SaOS-2, SaM-1) [162, 171, 172].

\section{Functional effects of $P 2$ receptor-mediated signalling in osteoblasts}

Extracellular nucleotides acting via $\mathrm{P} 2$ receptors have been shown to exert numerous effects on ostoeblast proliferation, differentiation, function, gene expression and cell signalling. The mitogenic effects of ATP were first reported by Suzuki et al. who showed that the ATP-stimulated $\mathrm{Ca}^{2+}$ influx resulted in synthesis of prostaglandin $\mathrm{E}_{2}\left(\mathrm{PGE}_{2}\right)$, which contributed to the ATP-induced proliferative action [155]. Subsequently, ATP acting via the P2X5 receptor was shown to promote DNA synthesis in human osteoblast-like MG-63 cells [171]. Adenosine was also reported to have mitogenic actions on MC3T3-E1 osteoblast-like cells, stimulating 
DNA synthesis and enhancing platelet-derived growth factor-induced mitogenesis [150].

A number of investigations have examined the intracellular signalling pathways activated in osteoblasts following P2Y receptor stimulation. An early study reported that ATP stimulated phospholipase (PL) D in a $\mathrm{Ca}^{2+} /$ calmodulin-dependent manner in osteoblasts, with neither PKC activation nor GTPbinding protein being involved [173]. More recently, it was shown that $\mathrm{P} 2 \mathrm{Y}_{2}$ receptor-mediated stimulation of osteoblasts involved activation of ERK 1/2 and p38 mitogen-activated protein kinase (MAPK) pathways [174]. $\mathrm{P}_{2} \mathrm{Y}_{2}$ receptor stimulation by ATP has also been shown to induce JNK1 phosphorylation in osteoblast-like cells, and this signalling mechanism was suggested to play a role in the bone remodelling induced by ATP since it could stimulate osteoblast proliferation [175]. The proliferative effect of ATP involves the participation of the PI3K/Akt signalling pathway in rat osteoblasts [176] and also in differentiation induced by ATP and UTP via $\mathrm{P}_{2} \mathrm{Y}_{2}$ receptors [177]. Furthermore, G protein-coupled receptor kinase 2 inhibits ATP-induced activation of the ERK1/2 signalling pathway in MC3T3-E1 osteoblastic cells, and this was suggested to play a role in mechano-desensitization in osteoblasts [178].

ATP stimulates the early growth response protein 1 via a PKC-dependent pathway in human osteoblast-like HOBIT cells [179]. Runx2, a bone-related transcription factor required for osteoblast differentiation and bone formation, is activated by ATP and UTP in HOBIT cells. It was suggested that this underlies the link between mechanical stress and the response of osteoblasts, through release of nucleotides [180]. Pre-stress in the cytoskeleton of cells affects the magnitude of cellular responses to mechanical stimuli. ATP was shown to reduce pre-stress by monitoring the rate of collagen gel compaction [181] via MAPK and nuclear factor $\kappa B(N F-\kappa B)$ pathways [182]. A novel $\mathrm{Ca}^{2+}$-activated $\mathrm{K}^{+}$channel (IK) is expressed by human osteoblasts, and ATP-induced hyperpolarization was inhibited by IK channel blockers [183]. Using green fluorescent-labelled paxillin fusion protein as a marker, it was shown that stimulation of osteoblasts with extracellular ATP induced the formation of short-living membrane protuberances [184].

Purinergic signalling can interact with other intracellular pathways to regulate osteoblast function. In early studies, P2 receptors were shown to mediate the potentiation of parathyroid hormone receptor-mediated increases in $\left[\mathrm{Ca}^{2+}\right]_{i}$ and $\mathrm{InsP}_{3}$ in UMR-106 rat osteoblasts $[185,186]$. Synergistic co-activation by ATP acting via P2Y receptors and parathyroid hormone was found to increase mRNA levels for $c$ fos, a transcription factor with a pivotal role in osteoblastic activation and bone remodelling. It was suggested that this may be a mechanism to generate strong localised responses to systemic growth and differentiation factors [187]. In a later study, it was shown that parathyroid hormone potentiated nucleotide-induced $\left[\mathrm{Ca}^{2+}\right]_{\mathrm{i}}$ release in rat osteoblasts independently of $\mathrm{G}_{\mathrm{q}}$ activation or cyclic adenosine monophosphate (cAMP) accumulation [163]. However, in a more recent study of MC3T3-E1 osteoblastic cells, parathyroid hormone enhanced bone morphogenetic protein activity by increasing intracellular cAMP accumulation to promote new bone formation [188]. Additionally, the regulator of $G$ protein signalling protein 2 in osteoblasts was upregulated by both extracellular ATP and parathyroid hormone and this contributes to cross-desensitization of $\mathrm{G}_{\mathrm{s}}-$ and $\mathrm{G}_{\mathrm{q}}$-coupled signals [189].

It has been demonstrated that ATP can induce the release of IL-6 [162], arachidonic acid via a PLD pathway [190] and synergise with glucose-dependent insulinotropic polypeptide to induce $c$-fos in osteoblastic cells [191]. There was also early recognition that locally released ATP could set up calcium waves between osteoblasts, mediated by $\mathrm{P}_{2} \mathrm{Y}_{2}$ receptors and connexin 43 hemichannels [164].

P2Y receptors have been implicated in the oscillatory fluid flow-induced intracellular $\mathrm{Ca}^{2+}$ mobilization in osteoblastic cells [192]. Furthermore, oscillating fluid flow activation of gap junction hemichannels between osteocytes and osteoblasts induces the release of ATP from MLO-Y4 osteocytes [193]. P2Y receptors and gap junctions are also involved in the propagation of intercellular calcium waves during osteoblast differentiation in vitro [194]. Calcium wave propagation was significantly impeded when extracellular ATP, released in response to mechanical stimulation, was hydrolysed by apyrase. This implied that ATP diffusion, rather than transport through gap junctions, is the underlying mechanism, involving P2Y receptors and release of $\mathrm{Ca}^{2+}$ from intracellular stores $[195,196]$. A study also demonstrated that cyclic hydraulic pressure and fluid flow differentially modulate cytoskeleton re-organization in MC3T3 osteoblasts. This was suggested to contribute to the loss of mechanosensitivity with extended loading [197].

Reactive oxygen species, such as $\mathrm{H}_{2} \mathrm{O}_{2}$, mediate $\left[\mathrm{Ca}^{2+}\right]_{\mathrm{i}}$ activity in primary rat osteoblasts by increasing $\mathrm{Ca}^{2+}$ release from intracellular stores [198], through sensitization of $\mathrm{P}_{2} \mathrm{Y}_{2}$ receptors [199]. It was suggested that mild oxidative conditions, represented by $\mathrm{H}_{2} \mathrm{O}_{2}$, could activate purinergic signalling through the sensitization of $\mathrm{P}_{2} \mathrm{Y}_{2}$ receptors [200]. ATP was claimed to induce mineralisation of MC3T3-E1 osteoblast-like cells and three phosphatases acted synergistically to promote ATP-mediated mineralisation [201]. However, a number of other investigations have observed the opposite effect. Initial functional studies showed that low micromolar concentrations of ATP and UTP acting via $\mathrm{P}_{2} \mathrm{Y}_{2}$ receptors inhibited bone formation by cultured rat osteoblasts $[11,202]$. A follow-up investigation demonstrated that ATP and UTP selectively inhibited the mineralisation of the organic matrix and provided further evidence for involvement of the $\mathrm{P}_{2} \mathrm{Y}_{2}$ receptor subtype [203]. Subsequent skeletal analysis of 
$\mathrm{P}_{2} \mathrm{Y}_{2}$ receptor knockout mice by dual energy X-ray absorptiometry (DEXA) and microcomputed tomography $(\mu \mathrm{CT})$ demonstrated large increases in trabecular and cortical bone parameters in the long bones [117, 204].

Recently, it was also demonstrated that the P2X1, P2X3 and P2X7 receptor agonists, $\alpha, \beta$-meATP, $\beta, \gamma$-methylene ATP and $2^{\prime}\left(3^{\prime}\right)-O$-(4-benzoylbenzoyl) adenosine $5^{\prime}$-triphosphate (BzATP) reduced bone mineralisation in vitro [167]. This study used selective P2 receptor antagonists to suggest that the effects were mediated via the $\mathrm{P} 2 \mathrm{X} 1$ and $\mathrm{P} 2 \mathrm{X} 7$ receptor subtypes [167]. Furthermore, a recent investigation demonstrated increased bone mineralisation in osteoblast cultures treated with apyrase, suggesting that endogenous ATP released by osteoblasts acts as an important local brake on mineralisation [205]. Combined these data suggests that ATP acts as a key endogenous inhibitor of bone mineralisation.

Clopidogrel $\left(\mathrm{Plavix}^{\circledR}\right)$ is a selective $\mathrm{P}^{2} \mathrm{Y}_{12}$ receptor antagonist. It is an antithrombotic prescribed to reduce the risk of heart attack and stroke, acting via inhibition of platelet aggregation. Low micromolar concentrations of clopidogrel have been shown to inhibit osteoblast proliferation, differentiation and function and reduce cell viability [168]. Reduced trabecular bone was also observed in ovariectomised mice treated with clopidogrel for 4 weeks [168]. In contrast, a paper by $\mathrm{Su}$ et al. [120] demonstrated increased bone in mice treated with clopidogrel. However, the two investigations used very different dosing regimes (oral dosing compared to clopidogreltreated water), and thus, the divergent results may reflect variations in the final dose received by the test subjects. In agreement with this idea, a study looking at a cohort of Danish patients found that clopidogrel was associated with fracture risk; however, these effects were biphasic with high doses (the recommended range) being associated with increased fracture risk and low doses being associated with decreased fracture risk [206].

Studies using the $\mathrm{P} 2 \mathrm{Y}_{13}$ receptor knockout mouse model demonstrated reduced trabecular bone mass, decreased osteoblast numbers in vivo and a reduced rate of bone remodelling indicating a role for this receptor in bone turnover [121]. The P2 $\mathrm{Y}_{13}$ receptor has also been shown to play an important role in the terminal differentiation of osteoprogenitor cells into osteoblasts or adipocytes [207].

Despite expressing all P2X receptor subtypes, the effects of $\mathrm{P} 2 \mathrm{X}$ receptor activation on osteoblasts remain poorly investigate. The main exception being the $\mathrm{P} 2 \mathrm{X} 7$ receptor, which has been the focus of numerous studies often with conflicting results. Early investigations demonstrated that functional P2X7 receptors expressed by a subpopulation of human differentiated osteoblasts mediated apoptotic cell death [169, 208]. Functional studies of $P 2 X 7$ receptor activation have shown increased [209] and decreased [167] bone formation in response to Bz-ATP. P2X7 receptors mediate blebbing in osteoblasts via a pathway involving lysophosphatidic acid, and it was suggested that this pathway may contribute to P2X7 receptor-stimulated osteogenesis during skeletal development and mechanotransduction [209, 210].

P2X7 receptor antagonists significantly inhibit ATP release from osteoblasts [211] and $c$-fos activation in response to fluid flow [212]. Fluid shear stress can also regulate gene expression in osteoblasts, in part by activation of the transcription factor NF-kB, through $\mathrm{P} 2 \mathrm{X} 7$ and $\mathrm{P}_{2} \mathrm{Y}_{6}$ receptors [213]. Brief activation of $\mathrm{P} 2 \mathrm{X} 7$ receptors on MC3T3-E1 osteoblast-like cells has been shown to trigger a dramatic $\mathrm{Ca}^{2+}$-dependent stimulation of metabolic acid production [214]. It was proposed that an acidic zone beneath the active osteoblast layer may prevent premature mineralisation of the osteoid seam during bone formation or that acid production by cells of the osteoblast lineage may activate osteoclastic resorption. It has also been reported that $\mathrm{P} 2 \mathrm{X} 7$ receptors play a role in ovariectomy-induced bone loss in mice [215] and callus remodelling during fracture repair [216].

It has been suggested that ATP, perhaps via $\mathrm{P} 2 \mathrm{X} 7$ receptor activation, mediates prostaglandin synthesis in response to fluid shear and may contribute to the response of bone to mechanical loading [138, 217]. Furthermore, fluid shearinduced ERK1/2 phosphorylation requires $\mathrm{Ca}^{2+}$-dependent ATP release and mediation via $\mathrm{P} 2 \mathrm{X} 7$ (but not $\mathrm{P} 2 \mathrm{Y}_{2}$ ) receptors $[218,219]$. Additionally, it has been claimed that the P2X7 receptor is involved in propagation of calcium waves in mature osteoblasts [208].

A number of studies using P2X7 receptor knockout mice from different genetic backgrounds have been performed. The initial study by $\mathrm{Ke}$ et al. [137] reported a decreased bone mineral content and periosteal circumference accompanied by decreased bone formation parameters and increased bone resorption parameters [137]. A separate study by Gartland et al. [136] reported no differences in bone mineral density of trabecular bone, but an increase in cortical bone was observed. It was subsequently reported that the knockout model used by Gartland et al. expresses a P2X7 splice variant in some tissues [220]; therefore, the results from this model should be interpreted with caution. Further complicating the analysis of the $\mathrm{P} 2 \mathrm{X} 7$ receptor knockout mouse model, a recent study demonstrated that the genetic background of the mouse strain used strongly influences the bone phenotype [122]. Gain of function polymorphisms of the P2X7 receptor have been associated with increased bone mass [221], whilst loss of function polymorphisms have been associated with increased fracture risk, reduced bone mineral density and osteoporosis [222-224].

A number of P2 receptors (P2X2, P2X3, P2X4, P2X6, $\mathrm{P}_{2} \mathrm{Y}_{4}, \mathrm{P}_{2} \mathrm{Y}_{6}$ and $\mathrm{P} 2 \mathrm{Y}_{14}$ ) expressed by osteoblasts still have no known functional effects and present interesting areas for future study. Of particular note is the P2X4 receptor, which displays the highest expression of all the P2 receptors present on osteoblasts [167]. Furthermore, given that 
osteoblasts express all $\mathrm{P} 2 \mathrm{X}$ receptor subtypes, it is possible that they may combine to form functional heteromultimers. Heteromultimers often display the pharmacology of both participating subunits, thus increasing the diversity of ATPmediated signalling and downstream functional effects. At present, it is not known whether the presence of such heteromultimers would influence purinergic signalling in osteoblasts.

\section{ATP release from osteoblasts}

Controlled ATP release from osteoblasts was first described by Romanello et al. in 2001 [225]. Now a widely investigated area, there are many studies which indicate that the primary method of ATP release from osteoblasts is by vesicular exocytosis [217, 226-228]. However, it has also been suggested that maxi-anion channels [229] and the P2X7 receptor [211] may be involved in release of ATP from osteoblasts. Furthermore, a recent study has claimed that pannexin 1 channels, in concert with P2X7 receptors, form a molecular complex that underlies the hemichannel function in osteoblast mechanosignalling involving thaw release of ATP [230]. Ahnak, a 700-kDa scaffold protein, has also been shown to regulate ATP release and calcium signalling in osteoblasts in response to mechanical stimulation [231]. Evidence now suggests that controlled ATP release from osteoblasts leads to activation of sensory nerves via $\mathrm{P} 2 \mathrm{X}$ receptors [232].

The amount of ATP released from osteoblasts depends on their differentiation state, with mature, bone-forming cells releasing up to sevenfold more than immature, proliferating cells [228]. Several studies have demonstrated increased ATP release in response to different external stimuli including hypoxia [228], mechanical stress [233] and fluid flow [217, 225]. Recently a detailed study was undertaken on ATP release in response to different forms of mechanical stimulation of human osteoblast SaOS-2 cells, including turbulent fluid flow, laminar fluid flow, substrate strain and 3D compressive loading [234]. It was concluded that the concentration of ATP released in response to mechanical loading varied in a time-, direction- and strain-dependent manner representing a local mechanostat in bone that may influence osteogenesis.

Osteoblasts are a target for calcitropic hormones, including the steroid $1 \alpha, 25(\mathrm{OH})_{2}$ vitamin $\mathrm{D}_{3}(1,25 \mathrm{D}) .1,25 \mathrm{D}$ induces a regulated secretion of ATP in osteoblasts, in the absence of mechanical stimulation, through interaction with vitamin $\mathrm{D}$ receptors and potentiation of $\mathrm{Ca}^{2+}$ and $\mathrm{Cl}^{-}$signals required for vesicle fusion and exocytotic release [235]. 1,25D also induced exocytotic release from osteoblastic ROS 17/25 cells [236].

Ultrasound causes ATP release by osteoblasts in vivo, and it is suggested that this may contribute to accelerated fracture healing by enhancing osteoblast proliferation, increasing receptor activation of NF- $\mathrm{kB}$ ligand (RANKL) expression and decreasing osteoprotegerin expression by osteoblasts to promote osteoclastogenesis [237]. More recently, lowintensity pulsed ultrasound (LIPUS) treatment was shown to induce the release of ATP from osteoblasts and increase P2 $\mathrm{Y}_{1}$ receptor expression leading to proliferation [238]. The authors suggested that this underlies the mechanism whereby LIPUS leads to accelerated fracture healing.

In osteoblast-like cells, bisphosphonates, used for treatment of osteoporosis, have been reported to induce ATP release which then acts via P2Y receptors to activate ERKs [239].

\section{ATP hydrolysis and the effects on bone mineralisation}

Once it is released, ATP is rapidly broken down by a hydrolysis cascade involving a number of ecto-nucleotidases. Molecular and functional characterisation has shown there are four families of ecto-nucleotidases: (1) the NTPdases (ectonucleoside triphosphate diphosphohydrolase); (2) the NPPs (ecto-nucleotide pyrophosphatase/phosphodiesterase); (3) alkaline phosphatases; and (4) ecto-5'-nucleotidase [240]. Many ecto-nucleotidases have overlapping specificities. For example, NTPdases catalyse the reactions NTP $\rightarrow \mathrm{NDP}+$ phosphate $\left(\mathrm{P}_{\mathrm{i}}\right)$ and NDP $\rightarrow$ NMP $+\mathrm{P}_{\mathrm{i}}$, whereas NPPs hydrolyse NTP $\rightarrow$ $\mathrm{NMP}+$ pyrophosphate $\left(\mathrm{PP}_{\mathrm{i}}\right)$ or $\mathrm{NDP} \rightarrow \mathrm{NMP}+\mathrm{P}_{\mathrm{i}}$.

An early study using human SaOS-2 osteoblast-like cells showed coexistence of both ATP-consuming and ATPgenerating activities on the cell surface [241]. Expression of multiple NTPdases and NPPs by osteoblasts has now been reported [203, 204]. Of these, NPP1 has emerged as having a particularly important role in bone. NPP1 converts extracellular ATP into AMP and $\mathrm{PP}_{\mathrm{i}}$, the potent inhibitor of bone mineralisation. A recent detailed study of the mouse model lacking NPP1 showed that this enzyme is essential for normal bone development and control of physiological bone mineralisation [242]. It is now becoming apparent that extracellular ATP is a key source of $\mathrm{PP}_{\mathrm{i}}$ in bone [205]. Thus, it is likely that nucleotide triphosphates exert a dual inhibitory action on bone mineralisation via both $\mathrm{P} 2$ receptor-mediated signalling and direct hydrolysis to $\mathrm{PP}_{\mathrm{i}}[111,203,205]$ (Fig. 2).

\section{P1 receptors, adenosine and osteoblasts}

The role of adenosine and P1 receptor-mediated signalling has become an area of increasing interest (see detailed review by [243]). An important early study showed that human osteoblast precursors produced extracellular adenosine, probably via breakdown of released ATP, which modulated their secretion of IL-6 and osteoprotegerin [244].

Human osteoblasts progenitor $\mathrm{HC} 1$ and bone marrow stomal (BMS) cells also show ecto-5'-nucleotidase (CD73) activity and express all four adenosine receptor subtypes, stimulation of which led to an increase in release of IL-6, which promotes osteoblastogenesis. Agonists to $\mathrm{A}_{1}$ and $\mathrm{A}_{2 \mathrm{~A}}$ receptors promote proliferation of osteoprogenitor and BMS cells, while 


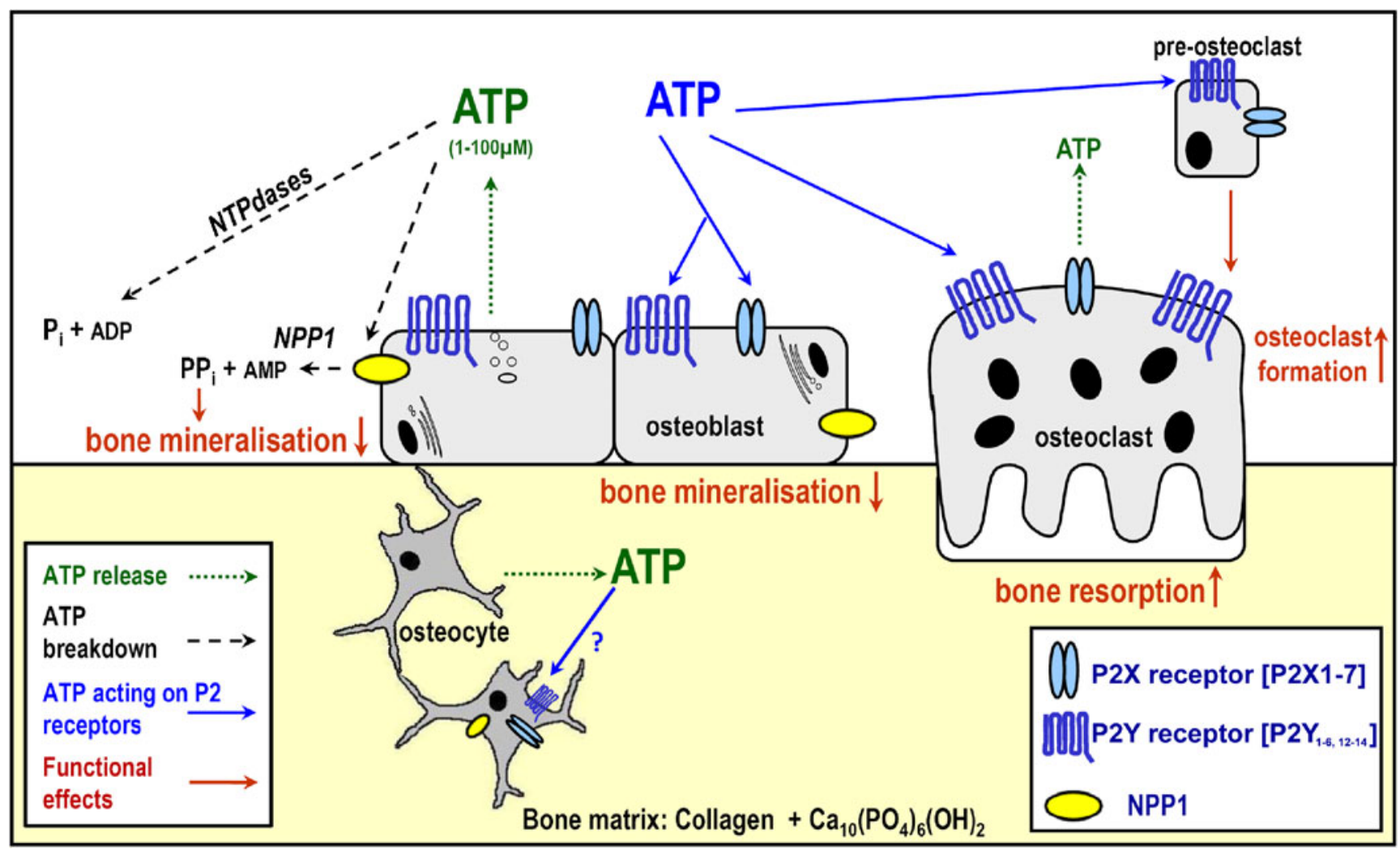

Fig. 2 Overview of the known functional effects of ATP on bone cells. ATP released from osteoblasts, osteocytes and osteoclasts can act locally to inhibit bone mineralisation and stimulate osteoclast formation and activity. ATP breakdown products can also act to influence bone cell function

$\mathrm{A}_{2 \mathrm{~B}}$ receptor agonists promote differentiation [245]. Recently, CD73 knockout mice were used to show a potential role for adenosine in osteoblast differentiation [246]. Whilst another paper, using $\mathrm{A}_{2 \mathrm{~B}}$ receptor knockout mice, identified this receptor as mediating the differentiation of mesenchymal stem cells into osteoblasts [247]. Adenosine was also shown to afford some protection against the death of MC3T3-E1 osteoblasts exposed to $\mathrm{H}_{2} \mathrm{O}_{2}$-induced oxidative stress [248].

\section{Osteocytes}

Osteocytes account for about $90 \%$ of all bone cells, yet little is known about the role of purinergic signalling in their survival and function. The primary purpose of osteocytes appears to be sensing mechanical load. They form an interconnected cell network located in the fluid-filled lacunocanaliculi system, an ideal position to translate mechanical signals into biochemical signals to effector cells, to facilitate regulation of bone remodelling. When this osteocyte network was exposed to a steady fluid flow, calcium transients were recorded that were reduced by both suramin and thapsigargin [249], suggesting that this was due to ATP acting via P2Y receptors. Osteocytes express T-type voltage-sensitive calcium channels; the $\alpha 2 \delta_{1}$ auxiliary subunit of which regulates mechanically-induced release of ATP from osteocyte cells [250]. Given that ATP can inhibit bone mineralisation, it is conceivable that release from osteocytes in vivo could act to reduce progressive, agerelated mineral encroachment from the surrounding bone (to which they have a very high surface area of exposure), thus preventing eventual cell 'fossilation' and death (see Fig. 2).

Recently, RT-PCR and pharmacological analysis showed that $\mathrm{P} 2 \mathrm{Y}_{2}$ and $\mathrm{P} 2 \mathrm{X} 7$ receptors were functionally expressed in MLO-P2 $\mathrm{Y}_{4}$ osteocytes as well as the ability of these cells to release ATP upon mechanical stimulation [251] and UTP stimulation [252].

\section{Osteoclasts}

\section{P2 receptor expression by osteoclasts}

Osteoclasts, the bone-resorbing cells, are usually multinuclear and are formed from mononuclear progenitors of the monocyte/macrophage lineage. The first report of P2 receptor expression by osteoclasts came in the early 1990s, when it was shown that ATP induced a large, fast and transient increase in $\left[\mathrm{Ca}^{2+}\right]_{\mathrm{i}}$ in rabbit osteoclasts. This effect was inhibited by thapsigargin implying mediation by $\mathrm{P} 2 \mathrm{Y}$ receptors [10]. Activation of the osteoclast ATP receptor was later shown to cause a transient decrease in intracellular $\mathrm{pH}$ [253]. The human P2U ( $\left.\mathrm{P}_{2} \mathrm{Y}_{2} / \mathrm{P}_{2} \mathrm{Y}_{4}\right)$ receptor was subsequently cloned and sequenced from osteoclastoma, indicating that this receptor was probably also expressed by osteoclasts [156]. Early 
studies also provided evidence for the presence of both P2X receptors, giving rise to non-selective cation currents, and P2Y receptors, mediating $\mathrm{Ca}^{2+}$ release from intracellular stores causing activation of a $\mathrm{Ca}^{2+}$-dependent $\mathrm{K}^{+}$channels $[254,255]$. P2X 4 receptors were initially claimed to mediate ATP-activated non-selective cation currents in rabbit osteoclasts [256]. However, it was later found that the nucleotideinduced elevation of $\left[\mathrm{Ca}^{2+}\right]_{\mathrm{i}}$ arose primarily from activation of P2Y rather than P2X4 receptors [257].

Expression of multiple $\mathrm{P} 2$ receptor subtypes by osteoclasts has now been reported. Initial studies using rat long bonederived osteoclasts showed expression of mRNA and protein for the P2X2, P2X4, P2X7, $\mathrm{P}_{2} \mathrm{Y}_{1}$ and $\mathrm{P}_{2} \mathrm{Y}_{2}$ receptors [166]. Human osteoclasts generated from peripheral blood were later shown to express the P2X1, P2X4, P2X7, P2 ${ }_{1}, \mathrm{P}_{2} \mathrm{Y}_{2}, \mathrm{P}_{2} \mathrm{Y}_{4}$, $\mathrm{P}^{2} \mathrm{Y}_{6}$ and $\mathrm{P} 2 \mathrm{Y}_{11}$ receptors [258]. Recently, osteoclasts derived from mouse bone marrow were shown to express all P2 receptors, with the exception of the $\mathrm{P} 2 \mathrm{X} 6$ and $\mathrm{P}_{2} \mathrm{Y}_{4}$ receptors [119]. This study also demonstrated large differences in the expression levels of the different $\mathrm{P} 2$ receptors, with the $\mathrm{P}_{2} \mathrm{Y}_{6}$ receptor being the most abundant [119].

\section{Functional effects of $P 2$ receptor-mediated signalling in osteoclasts}

Involvement of P2 receptors in the regulation of osteoclast function was first proposed in 1995 by Bowler et al. [156] after ATP was found to stimulate resorption by cells from human osteoclastoma. Originally, this effect was proposed to be mediated via the $\mathrm{P} 2 \mathrm{Y}_{2}$ receptor; however, in a follow-up study, UTP failed to stimulate resorption suggesting this was not the case [259]. Subsequently, ATP was found to stimulate the formation and activity of rodent osteoclasts, effects which were inhibited by apyrase or suramin [12]. These stimulatory actions on resorption were further increased when osteoclasts were first activated by culture in acidified medium [12]. Since the $\mathrm{P} 2 \mathrm{X} 2$ receptor is the only $\mathrm{P} 2$ receptor subtype that requires extracellular acidification to show its full sensitivity to ATP [260], it was suggested that these pro-resorptive effects could involve the P2X2 receptor. Further investigation showed that low micromolar concentrations of ADP, 2-meththio ADP and ATP potently stimulated osteoclast formation and activity [261]. Pharmacological and cytochemical evidence suggested that these effects were mediated via $\mathrm{P}_{2} \mathrm{Y}_{1}$ receptors [261]. Analysis of skeletal changes in $\mathrm{P} 2 \mathrm{Y}_{1}$ receptor knockout mice by DEXA and $\mu \mathrm{CT}$ showed reduced trabecular bone in the long bones $[117,118]$. This decrease in bone mass was unexpected given the previously suggested role for the $\mathrm{P} 2 \mathrm{Y}_{1}$ receptor in osteoclast activity. However, a recent study found that ADP still stimulated osteoclast formation and resorption in cells derived from $\mathrm{P}_{2} \mathrm{Y}_{1}$ receptor knockout mice [120], suggesting the involvement of another P2Y receptor. Based on pharmacology, the logical alternative candidate for mediating the effects of ADP on osteoclasts was the $\mathrm{P}_{2} \mathrm{Y}_{12}$ receptor. The $\mathrm{P} 2 \mathrm{Y}_{12}$ receptor was only identified in 2001 [262], which was the same year as the initial study by Hoebertz et al. and thus was not considered in the original study. Furthermore, expression of the P2 $\mathrm{Y}_{12}$ receptor by osteoclasts has only recently been reported [119]. There is now evidence to suggest that the $\mathrm{P}_{2} \mathrm{Y}_{12}$ receptor plays a key role in mediating the effects of ADP on osteoclast formation and activity since cells derived from $\mathrm{P}_{2} \mathrm{Y}_{12}$ knockout mice display impaired responses to ADP [120]. Consistent with effects mediating osteoclast activity, $\mathrm{P} 2 \mathrm{Y}_{12}$ receptor knockout mice have increased trabecular bone and decreased arthritis associated bone loss [120]. Furthermore, clopidogrel, a $\mathrm{P} 2 \mathrm{Y}_{12}$ receptor antagonist, inhibits osteoclast formation, viability and resorptive activity [168].

It has also been suggested that ATP stimulates human osteoclast activity indirectly through upregulation of osteoblastexpressed RANKL [258], and that these effects are probably mediated via P2X7 receptors [263]. Interestingly, osteoclasts isolated from human deciduous teeth respond to ATP by activating $\mathrm{K}^{+}$and $\mathrm{Cl}^{-}$currents, and this may also contribute to the stimulatory effects of ATP on bone resorption [264].

It is now emerging that the $\mathrm{P}_{2} \mathrm{Y}_{6}$ receptor may play an important role in osteoclasts. The $\mathrm{P}_{2} \mathrm{Y}_{6}$ receptor has been implicated in osteoclast survival since activation by its agonist, uridine diphosphate (UDP), prevented the apoptosis induced by tumour necrosis factor- $\alpha$ (TNF- $\alpha$ ) [265]. UDP also induced the translocation and activation of NF- $\mathrm{KB}$ in osteoclasts and their precursors [265]. Recently, activation of the $\mathrm{P} \mathrm{Y}_{6}$ receptor by UDP has been shown to stimulate osteoclast formation and activity [119]. Consistent with a role for this receptor in bone resorption, osteoclasts derived from $\mathrm{P}_{2} \mathrm{Y}_{6}$ receptor knockout mice displayed defective function [119]. Analysis of $\mathrm{P}_{2} \mathrm{Y}_{6}$ receptor knockout mice by $\mu \mathrm{CT}$ revealed increased cortical bone in the long bones and spine [119].

The effect of $\mathrm{P} 2 \mathrm{Y}_{13}$ receptor activation on osteoclast function requires further investigation. However, $\mathrm{P}_{2} \mathrm{Y}_{13}$ receptor knockout mice display reduced osteoclast numbers in vivo with protection from ovariectomy-induced bone loss in females [121].

The role of the $\mathrm{P} 2 \mathrm{X} 7$ receptor on osteoclast formation and activity appears complex. An initial study showed that P2X7 receptors enhanced giant cell formation [128]. High concentrations of ATP were also reported to activate P2X7 receptors on rabbit osteoclasts, and it was suggested that ATP released in response to mechanical stimuli may act via P2X7 receptors to inhibit osteoclastic resorption [266]. Experiments using cells derived from human peripheral blood showed that antagonism of the P2X7 receptor with oxidised ATP or a monoclonal antibody inhibited the fusion of osteoclast precursors to form multinucleated osteoclasts [267]. Analogues of the P2X7 receptor antagonist, KN-62, have also been shown to induce osteoclast apoptosis [268]. In contrast, Ke et al. demonstrated that P2X7 receptor knockout mice possessed functional osteoclasts in vivo [137]. In addition, using knockout precursor cells, osteoclasts 
were generated in vitro, suggesting that the $\mathrm{P} 2 \mathrm{X} 7$ receptor is not required for cell fusion [137]. Other studies have also shown that P2X7 receptor knockout mice retain the ability to form multinucleated cells both in vitro and in vivo [114, 116]. RAW 264.7 osteoclast-like cells display P2X7 pore-forming activity and prolonged exposure to ATP was found to down-regulate P2X7 receptor function and inhibit osteoclast formation [269].

Activation of the $\mathrm{P} 2 \mathrm{X} 7$ receptor has also been shown to induce the translocation of NF-KB [263] and an isoformspecific PKC in osteoclasts and their precursors [270]. The $\mathrm{P} 2 \mathrm{X} 7$ receptor may additionally play a role in the intercellular communication between osteoblasts and osteoclasts [271], cytoskeletal reorganisation at the sealing zone and the delivery and secretion of lytic granules into the resorption lacunae [272]. Recently, it was shown that ATP release from osteoclasts is mediated via the $\mathrm{P} 2 \mathrm{X} 7$ receptor $[211,273]$. Thus, this receptor is thought to drive osteoclast fusion by increasing the concentration of extracellular adenosine (via breakdown of released ATP) [273] (see Fig. 3).

How stimulation of the P2X1 P2X2, P2X3, P2X4, P2X5, $\mathrm{P} 2 \mathrm{Y}_{2}$ and $\mathrm{P} 2 \mathrm{Y}_{14}$ receptors influences osteoclast formation and activity remains to be established; however, a number of other effects of extracellular ATP on osteoclasts have been reported. Osteoclasts secrete L-glutamate upon stimulation by ATP [274] and ATP released from osteoclasts is thought to sensitise bone to the action of parathyroid hormone and other systemic hormones [275]. Chemical sympathectomy was found to impair bone resorption in rats [276], perhaps mediated by ATP released as a cotransmitter acting on osteoclasts. Furthermore, ATP flowing from cells after surgery can directly activate $\mathrm{P} 2 \mathrm{X} 4$ receptors on the sensor cells of marginal gingiva or by direct activation of osteoclasts on the bone surface [277]. A recent study suggested that intracellular ATP levels play a pivotal role, not only in osteoclast apoptosis, but also in the bone-resorbing function of the cells [278]. Bisphosphonates are highly effective inhibitors of bone resorption via a

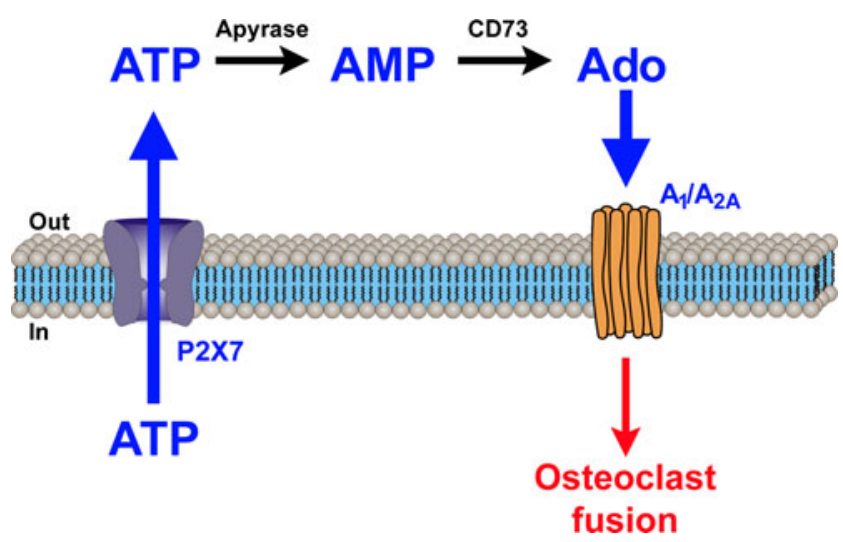

Fig. 3 Schematic diagram showing release of ATP from osteoclasts via P2X7 receptors, where it undergoes enzymatic breakdown to AMP (via apyrase) and adenosine (Ado; via CD73). Ado acts on P1 ( $\mathrm{A}_{1}$ and/or $\left.\mathrm{A}_{2 \mathrm{~A}}\right)$ receptors to stimulate osteoclast fusion mechanism involving a novel ATP analogue (1-adenosin-5'yl ester 3-(3-methylbut-3-enyl)) ester triphosphoric acid (ApppI) that leads to the accumulation of isopentenyl pyrophosphate; ApppI then induces osteoblast apoptosis [279].

\section{$P 1$ receptors, adenosine and osteoclasts}

A potential role for adenosine in regulating osteoclast function was first suggested in the 1980s when 2-chloroadenosine, an agonist at $\mathrm{P} 1$ receptors, was shown to stimulate bone resorption in calvarial bones in organ culture; however, the underlying mechanism was not clear [280]. It was later proposed that $\mathrm{PGE}_{2}$ and 2-chloroadenosine act in concert to stimulate bone resorption [281]. Adenosine produced after hydrolysis of ATP released from osteoprogenitor and BMS cells acts on P1 receptors leading to the release of IL-6 and inhibition of osteoprotegerin secretion, which results in the stimulation of osteoclastogenesis [244]. It has been shown that endogenous adenosine acting via $A_{1}$ receptors on osteoclasts and their precursor cells plays a critical role in regulating bone turnover [282]. $A_{1}$ receptor antagonists regulate osteoclastogenesis by bone marrow osteoclast precursor cells by inhibiting RANKLinduced activation of the JNK/c-Jun pathway [283]. Consistent with these findings, $A_{1}$ receptor knockout mice display increased bone mineral density and resistance to ovariectomyinduced bone loss [284]. ATP released through P2X7 receptors acts as the major source of adenosine that enhances mature osteoclast function via $\mathrm{A}_{2 \mathrm{~A}}$ receptors [273]. However, a later study showed that adenosine, acting through $\mathrm{A}_{2 \mathrm{~A}}$ receptors, inhibited osteoclast differentiation [285]. Thus, the authors suggested that adenosine may regulate bone turnover under conditions when levels are elevated [285]. $\mathrm{A}_{2 \mathrm{~A}}$ receptor activation has also been shown to prevent the osteolysis that occurs during prosthesis loosening with particle-induced inflammation, a common cause of joint implant failure [286]. In addition, adenosine blocks aminopterin-induced suppression of osteoclast differentiation and osteoclastogenesis [287].

Bone marrow stromal cells or mesenchymal stem cells

A key function of bone is to protect the bone marrow, the site of blood cell formation. Osteoblasts and lining cells (or quiescent osteoblasts) located on the bone surface form a continuum with stromal cells of bone marrow. It has been reported that osteoclasts promote the formation of hematopoietic stem cell niches in bone marrow [288]. Osteoblasts, adipocytes and chondrocytes are all derived from mesenchymal stem cells (MSCs) and thus these cells play a key role in bone. The number of investigations examining the role of purinergic signalling in MSCs is limited; however, an important role for extracellular nucleotides in regulating MSC proliferation and differentiation is emerging. Initial studies demonstrated that fluid flow induced vesicular release of ATP from 
human MSCs, which then stimulated their proliferation via purinoceptor-mediated increase in $\left[\mathrm{Ca}^{2+}\right]_{\mathrm{i}}[289]$. UTP and, to a lesser extent, ATP were also shown to stimulate human MSC migration [290]. Human MSCs express all P2Y receptors and the P2X3-7 receptors [291, 292]. Recently, extracellular nucleotides have been reported to modulate the differentiation of human MSCs, with the $\mathrm{P} 2 \mathrm{X} 6, \mathrm{P}_{2} \mathrm{Y}_{4}$ and $\mathrm{P}_{2} \mathrm{Y}_{14}$ receptors identified as playing pivotal roles in this process [292, 293]. UDP activation of $\mathrm{P}_{2} \mathrm{Y}_{6}$ receptors has also been shown to regulate the osteogenic differentiation of the primary MSCs from postmenopausal women [291]. The same study also demonstrated that NTPDases influence which osteoblast progenitors are driven into proliferation or differentiation [291]. Furthermore, a detailed investigation using knockout mice identified that the $\mathrm{P} 2 \mathrm{Y}_{13}$ receptor regulates the terminal differentiation of MSCs into osteoblasts or adipocytes [207].

In terms of P1 receptor signalling, many of the studies investigating the role of adenosine in osteoblasts have utilised MSCs (see above). However, activation of $A_{1}, A_{2 A}, A_{2 B}$ and $A_{3}$ receptors has been shown to increase the proliferation (mainly via $A_{1}$ and $A_{2 A}$ receptors) and differentiation (mainly via $A_{2 B}$ receptors) of MSCs [245]. Adenosine also inhibits chemotaxis and induces hepatocyte-specific genes in MSCs [294].

\section{Cartilage and chondrocytes}

Cartilage is a flexible connective tissue found in many areas of the body, in the skeletal system it is particularly important in the joints. The extracellular matrix of cartilage is composed of collagen, abundant ground substance rich in proteoglycans and elastin fibres. This matrix is produced by chondroblasts, which, when they become embedded within the extracellular matrix in lacunae, are called chondrocytes. Cartilage does not contain blood vessels since chondrocytes produce an antiangiogenesis factor that discourages their formation.

\section{P2 receptor expression by chondrocytes}

Purinergic receptor expression in cartilage was first suggested in the early 1990s when ATP was shown to stimulate resorption of bovine nasal cartilage, an effect that was not mediated by adenosine or prostaglandins [295]. The following year, ATP was shown to simulate $\mathrm{PGE}_{2}$ production from articular chondrocytes [296]. P2 receptors were later identified on human articular chondrocytes that were responsive to UTP as well as ATP [297]. Subsequently, P2U (P2 $\mathrm{Y}_{2}$ and/or P2Y $\left.\mathrm{Y}_{4}\right)$ receptors were identified on sheep chondrocytes [298, 299]. Chondrocytes have now been shown to express many P2 receptors including the $\mathrm{P} 2 \mathrm{X} 1, \mathrm{P} 2 \mathrm{X} 2, \mathrm{P} 2 \mathrm{X} 3, \mathrm{P} 2 \mathrm{X} 4, \mathrm{P} 2 \mathrm{X} 7$, $\mathrm{P} 2 \mathrm{Y}_{1}$ and $\mathrm{P} 2 \mathrm{Y}_{2}$ receptors [300-303]. Some of these receptors (P2X2, P2X4, P2X7 and P2 $\mathrm{Y}_{1}$ ) were expressed throughout all the zones of articular cartilage, whilst the $\mathrm{P}_{2} \mathrm{Y}_{2}$ receptor showed more limited expression only being present on superficial zone cells [302].

The presence of functional P2 receptors in chondrocytes has been demonstrated by a number of studies looking at intracellular $\mathrm{Ca}^{2+}$ levels. Early work showed that ATP and ADP induced a rise in $\left[\mathrm{Ca}^{2+}\right]_{\mathrm{i}}$ in growth plate chondrocytes [304], probably via P2Y receptors, since the calcium was released from intracellular stores. ATP also elevated $\left[\mathrm{Ca}^{2+}\right]_{\mathrm{i}}$ in retinoic acid-treated embryonic chondrocytes [305] and induced increases in $\left[\mathrm{Ca}^{2+}\right]_{\mathrm{i}}$ in human chondrons (chondrocytes surrounded by their native pericellular matrix and cultured in three-dimensional agarose films) [306]. In addition, UTP caused a transient increase in $\left[\mathrm{Ca}^{2+}\right]_{\mathrm{i}}$ and the release of ATP from cultured chondrocytes, effects that were reduced by suramin and blockers of $\mathrm{Cl}^{-}$channels [307].

Functional effects of $\mathrm{P} 2$ receptor-mediated signalling in chondrocytes

Early work suggested that ATP caused articular cartilage mineralisation by promoting matrix vesicle-mediated calcium deposition [308, 309]. A specific ATPase, rather than nonspecific alkaline phosphatase, was claimed to mediate this ATP-initiated calcification by matrix vesicles [310].

Recently, many of the studies describing the effects of purinergic signalling on cartilage have been conflicting with some reports suggesting that extracellular nucleotides negatively regulate cartilage metabolism whilst others describe beneficial effects of ATP. Activation of the $\mathrm{P}_{2} \mathrm{Y}_{1}$ receptor by ATP inhibited cartilage formation in micromass cultures of chick limb undifferentiated mesenchyme cells [311]. ATP was also reported to promote proteoglycan breakdown and glycosaminoglycan release in bovine nasal cartilage [312] and increase the production of inflammatory mediators, nitric oxide (NO) and $\mathrm{PGE}_{2}$ [303]. Furthermore, in articular chondrocytes, stimulation of $\mathrm{P} 2 \mathrm{Y}_{2}$ receptors by ATP increased IL-1mediated $\mathrm{PGE}_{2}$ release [300] and induced a rapid rise in $\mathrm{PGE}_{2}$ synthesis via an ERK1/2 and p38 MAPK-mediated activation of cytoplasmic $\mathrm{PLA}_{2}$ [313]. P2Y receptor signalling through MAPK/ERK was dependent on $\beta 3$ integrin ligation and was therefore influenced by the composition of the extracellular matrix [301]. In contrast, extracellular ATP and UTP stimulated cartilage proteoglycan and collagen accumulation in bovine chondrocyte pellet cultures [314, 315]. ATP, released by compression, also suppressed the release of $\mathrm{NO}$ and stimulated proteoglycan synthesis in chondrocytes/agarose constructs [316, 317].

The response of human articular chondrocytes to ATP is enhanced by IL- $1 \beta$ [297] and TNF- $\alpha[318,319]$. Activation of P2Y receptors also leads to elevated fibroblast growth factor-induced proliferation [298, 299]. In addition, ATP signalling via the $\mathrm{P} 2 \mathrm{X} 4$ receptor is thought to mediate the increased $\left[\mathrm{Ca}^{2+}\right]_{\mathrm{i}}$ required for chondrocyte differentiation [320]. 
A recent study has also shown that intracellular oscillations in ATP have a critical role in pre-chondrogenic condensation, via $\mathrm{P} 2 \mathrm{X} 4$ receptors [321] and mediate inductive action of fibroblast growth factor [322].

The repair of foetal, but not adult, articular cartilage involves ATP-induced increases in $\left[\mathrm{Ca}^{2+}\right]_{i}$ and expression of c-fos [323]. Thus, harnessing the ATP receptor pathway has been shown to be a highly effective approach to improve tissue formation and impart functional mechanical properties of engineered cartilage constructs used to repair damaged articular cartilage [324].

\section{ATP release and breakdown in cartilage}

The first direct evidence for ATP release from chondrocytes came in 2000 from a study by Graff et al. [325]. They showed that ATP was continuously released from chondrocytes at rest and in response to mechanical load to promote matrix mineralisation [325, 326]. Earlier, hypotonically induced stretch had been demonstrated to increase ion channel activity in cultured human articular chondrocytes [327], an effect which, in retrospect, was probably mediated via ATP release. Similarly, the increased $\left[\mathrm{Ca}^{2+}\right]_{\mathrm{i}}$ which is observed in articular chondrocytes following fluid flow [328] and pressure-induced strain [329] is probably due to the release of ATP. Additionally, ATP stimulation of $\mathrm{P} 2 \mathrm{Y}$ receptors elicits an increase in intracellular $\left[\mathrm{Ca}^{2+}\right]_{\mathrm{i}}$ which triggers further release of ATP from adjacent cells, thereby enhancing $\mathrm{Ca}^{2+}$ waves in chondrocytes [307]. There has been a recent report that $100 \mu \mathrm{M}$ ATP induced massive release of ATP from articular chondrocytes, probably as the result of $\mathrm{P} 2 \mathrm{X} 7$ receptor activation [330].

Physiological joint loading and the associated compression of articular cartilage produce events that influence both chondrocyte metabolism and extracellular matrix synthesis. It has been shown recently that primary cilia are essential for chondrocyte mechanotransduction and the control of extracellular matrix secretion; in particular, chondrocyte primary cilia are required for ATP release and purinoceptor-mediated $\mathrm{Ca}^{2+}$ signalling [331]. ATP transport from chondrocyte primary cilium was, at least in part, via connexin 43 hemichannels [302, 332]. Release of ATP via pannexin 3 hemichannels has also been proposed [333]. The authors suggested than pannexin 3 functioned to switch chondrocyte cell fate from proliferation to differentiation by regulating the intracellular ATP/cAMP levels.

ATPase activity in chondrocytes was first reported by in 1983 by Kanabe et al. [334]. It was later shown that the ecto-enzymes NTPDase, NPP, alkaline phosphatase and 5'nucleotidase, as well as adenylate kinase and nucleoside diphosphokinase which mediate regeneration of ATP, are differentially localised in cartilage [326]. P1 receptor agonists decreased extracellular $\mathrm{PP}_{\mathrm{i}}$ production surrounding chondrocytes and cartilage explants, while ADP increased $\mathrm{PP}_{\mathrm{i}}$ levels, suggesting a homeostatic role for $\mathrm{P} 1$ and $\mathrm{P} 2$ receptors in stabilizing concentrations of $\mathrm{PP}_{\mathrm{i}}[335]$.

P1 receptors, adenosine and chondrocytes

The regulation of chondrocyte function by $\mathrm{P} 1$ receptors was first suggested following the observation that adenosine inhibited proliferation and produced damage to cultured chondrocytes from rabbits [336]. Later, it was demonstrated that chondrocytes respond to adenosine via $\mathrm{A}_{2}$ receptors, activity which was potentiated by adenosine deaminase (ADA) and phosphodiesterase inhibitors [337]. Furthermore, pulsed electromagnetic fields produce an up-regulation of the $\mathrm{A}_{2 \mathrm{~A}}$ and $\mathrm{A}_{3}$ receptors that mediate proliferation of bovine chondrocytes and fibroblast-like synoviocytes [338], and $\mathrm{A}_{2 \mathrm{~A}}$ receptor activation reduces inflammation in mouse articular chondrocytes stimulated with IL-1 $\beta$ [339].

\section{Ligaments and tendons}

\section{Ligaments}

A role for purinergic signalling in ligaments has only recently emerged, and to date, most of the work has been performed on periodontal ligament cells. In these cells, ATP stimulates RANKL expression via a $\mathrm{P} 2 \mathrm{Y}_{1}$ receptor-cyclooxygenasedependent pathway [340]. Mechanical stress causes ATP release, which acts via $\mathrm{P} 2 \mathrm{Y}_{1}$ receptors to increase expression of osteopontin, a protein involved in bone remodelling [341, 342]. Evidence suggests that the ATP release from periodontal ligament cells occurs via connexin 43 hemichannels [343]. Furthermore, RT-PCR analysis has shown that these cells express mRNA for $\mathrm{P} 2 \mathrm{X} 7, \mathrm{P} 2 \mathrm{Y}_{1}, \mathrm{P} 2 \mathrm{Y}_{2}, \mathrm{P} 2 \mathrm{Y}_{4}, \mathrm{P} 2 \mathrm{Y}_{6}$ and $\mathrm{P}_{2} \mathrm{Y}_{12}$ receptors. Release of ATP from human periodontal ligament cells in response to mechanical stress also leads to IL-1 $\beta$ expression via P2X7 receptor activation [344]. Combined, these studies indicate that extracellular ATP may play an important physiological role in periodontal remodelling.

\section{Tendons}

There is significant evidence to suggest an important role for extracellular ATP in tendons. Human tendon cells respond to mechanical stimulation by increasing $\left[\mathrm{Ca}^{2+}\right]$. This effect was blocked by thapsigargin [345], suggesting that ATP was released and then activated $\mathrm{P} 2 \mathrm{Y}$ receptors. Indeed, a later paper showed that mechanical loading induced ATP release from tendon cells and stimulated expression of IL- $1 \beta$, cyclooxygenase- 2 and matrix metalloproteinases, triggering matrix remodelling or a destructive pathway [346]. The authors suggested that the released ATP may serve as a negative feedback mechanism to limit activation of the injurious 
pathways. Mechanical loading also stimulated ecto-ATPase activity in human tendon cells and motion may release ATP from tendon cells in vivo [347]. Thus, it was suggested that the ATP/ATPase system may be important for tendon homeostasis by protecting tendon cells from responding to excessive load signals. P2 receptor blockade with pyridoxalphosphate6-azophenyl-2',5'-disulfonic acid significantly attenuated the responses of group III myelinated afferent nerves to tendon stretch, contributing to the exercise pressor reflex [348], in keeping with the claim that mechanical stimulation releases ATP from tendon cells.

\section{Diseases of the musculoskeletal system}

\section{Skeletal muscle diseases}

ATP was used early in the therapy of myopathies ('Adotripos', Rona, UK), although the mechanism of action was unknown. In rat soleus muscles, the stimulatory effect of insulin on Dxylose uptake was progressively lost and was associated with the loss of muscle ATP; extracellular ATP promoted an effect of insulin in otherwise insulin-unresponsive muscles [349]. Exogenously added ATP was also shown to abolish the adverse actions of $\mathrm{PLA}_{2}$, local anaesthetics and the $\mathrm{Ca}^{2+}$ ionophore A23187, as well as lithium, on carbohydrate metabolism in the isolated rat diaphragm muscle [350]. It was suggested that ATP may have therapeutic potential, as it may stimulate the impaired glycolysis induced by various drugs and conditions which cause muscle weakness or damage.

Adult injured muscles undergo regeneration and connexin hemichannels are re-expressed in undifferentiated cells that form new myofibres, supporting the healing process of injured muscle following mediation of the release of ATP [92].

\section{Muscular dystrophy}

Duchenne muscular dystrophy (DMD) is the most common and severe of muscular dystrophies. It is caused by mutations in the dystrophin gene resulting in loss of dystrophin protein. Allopurinol has been used for the treatment of DMD since it counteracts the reduction in purine nucleotide degradation levels in Duchenne muscle. However, it has been reported that chronic administration of allopurinol and adenine does not improve the clinical status of DMD [351]. Early work revealed that lymphoblastoid cells from DMD patients were highly sensitive to stimulation by extracellular ATP [352].

Some muscular dystrophies are caused by a sarcoglycan gene mutation. $\alpha$-Sarcoglycan has been reported to have ectoATPase activity and it was suggested that the activity of P2X receptors may be modulated by $\alpha$-sarcoglycan which buffers the extracellular ATP concentration [353]. Elevated concentrations of extracellular ATP and its activation of P2X receptors lead to $\mathrm{Ca}^{2+}$ overload and muscle fibre death in the absence of $\alpha$-sarcoglycan in sarcoglycanopathies.

The $m d x$ model of DMD, which lacks dystrophin protein, has been used as a clinically relevant form of muscle damage and subsequent regeneration. Using a combination of immunohistochemistry, RT-PCR and electrophysiology, sequential expression of $\mathrm{P} 2 \mathrm{X} 5, \mathrm{P} 2 \mathrm{Y}_{1}$ and $\mathrm{P} 2 \mathrm{X} 2$ receptors was shown during the process of muscle regeneration in the $m d x$ model [354]. The P2X5 and $\mathrm{P} 2 \mathrm{Y}_{1}$ receptors were expressed first in activated satellite cells. The $\mathrm{P}_{2} \mathrm{Y}_{1}$ receptor was also expressed on infiltrating immune cells. $\mathrm{P} 2 \mathrm{X} 2$ receptor expression on newly formed myotubes showed colocalization with ACh receptors, suggesting a role for $\mathrm{P} 2 \mathrm{X} 2$ receptors in the regulation of muscle innervation. Evidence for the involvement of purinergic signalling in muscle regeneration may lead to novel therapeutic strategies for the treatment of muscle disease. Immortalized myoblast cell lines derived from the $m d x$ mouse (SC5) and control (dystrophin positive) myoblasts (IMO) from the same parent mouse strain have been used to investigate changes in P2X receptor expression and function in dystrophic muscle [355]. It was shown that a purinergic dystrophic phenotype arises at the earliest myoblast stage of developing dystrophic muscle. Dystrophic-negative myoblasts were more sensitive to ATP, resulting in increases in $\left[\mathrm{Ca}^{2+}\right]_{\mathrm{i}}$. P2X4 and $\mathrm{P} 2 \mathrm{X} 7$ receptor proteins were also expressed on dystrophic myoblasts. It was suggested that $\mathrm{P} 2 \mathrm{X} 4$ and $\mathrm{P} 2 \mathrm{X} 7$ receptor antagonists may be of potential therapeutic benefit.

Myofascial pain is common in DMD and ATP has been claimed to excite or sensitise myofascial nociceptors [356-358]. P2X7 receptor upregulation was shown in dystrophic $m d x$ mouse muscles and it was suggested that treatment with $\mathrm{P} 2 \mathrm{X} 7$ receptor antagonists might slow the progression of muscular dystrophy [359]. Sensitivity to ATP was reported to be much higher in $m d x$ mice [360]. ATP release is greater in $m d x$ mice and there is increased expression of $\mathrm{P}_{2} \mathrm{Y}_{2}$ receptors, but a decrease in $\mathrm{P}_{2} \mathrm{Y}_{1}$ receptors [361].

\section{Myasthenia gravis}

Myasthenia gravis is an autoimmune disease, affecting the neuromuscular junction. It has been reported that lack of neuronal $\mathrm{A}_{2 \mathrm{~A}}$ receptor-mediated $\mathrm{Ca}_{\mathrm{v}} 1$ (L-type) influx causes tetanic failure in myasthenia gravis [362].

\section{Fibromyalgia}

Fibromyalgia is characterised by pain and allodynia, as well as mood disorders. It has been considered as a musculoskeletal disease, but also more recently as a neuropsychiatric condition. It has been shown that there are significantly lower levels of ATP in platelets of fibromyalgia patients and it was suggested that this may be of relevance in the pathogenesis of the disease [363]. 
Bone and joint disorders

\section{Osteoporosis}

Osteoporosis is a condition characterised by a loss of bone mass (decreased bone mineral density), leading to increased risk of bone fracture. It occurs most commonly in postmenopausal women. Of the P2 receptor subtypes expressed by bone cells, it is the $\mathrm{P} 2 \mathrm{X} 7$ receptor which has received the most attention in relation to the treatment of osteoporosis. Initial work using animal models demonstrated that the P2X7 receptor plays an important role in both cortical and cancellous bone mass augmentation in rapidly growing female mice [364]. Furthermore, P2X7 receptors were shown to mediate stimulation of periosteal and cancellous bone formation and the inhibition of cancellous bone resorption during growth [115]. The $\mathrm{P} 2 \mathrm{X} 7$ receptor is highly polymorphic and a number of studies have shown that single nucleotide polymorphisms (SNPs) of the P2X7 receptor gene are associated with fracture risk, decreased bone mineral density and osteoporosis (see [222-224, 365]). P2X7 receptors are also involved in the complex chain of events leading to the formation of human osteoclasts, and it was suggested that $\mathrm{P} 2 \mathrm{X} 7$ receptor antagonists may be valuable for the management of osteoporosis and with disorders of remodelling, where there is reduced bone mass [366, 367].

Non-synonymous polymorphisms in the $\mathrm{P} 2 \mathrm{X} 4$ receptor gene and the Leu46Pro polymorphism of the human $\mathrm{P}_{2} \mathrm{Y}_{2}$ receptor gene have also been associated with bone mineral density and osteoporosis risk in a cohort of Dutch fracture patients [368]. Furthermore, it has been reported recently that clopidogrel, a $\mathrm{P}_{2} \mathrm{Y}_{12}$ receptor antagonist widely used for thrombosis and stroke, is associated with risk of osteoporotic fractures [206].

Adenosine receptors have also been implicated in osteoporosis [369]. Studies have suggested that endogenously released adenosine, acting on $\mathrm{A}_{1}, \mathrm{~A}_{2 \mathrm{~A}}$ and $\mathrm{A}_{2 \mathrm{~B}}$ receptors on osteoclasts and their precursor cells, plays a critical role in regulating bone turnover [370, 371]. Furthermore, transdifferentiation of osteoblasts to adipocytes, a process which involves $\mathrm{A}_{2 \mathrm{~B}}$ receptors, may also contribute to the pathogenesis of osteoporosis [372, 373]. Thus, $P 1$ receptors may be useful targets in treating diseases characterised by excessive bone turnover, such as osteoporosis.

\section{Periodontitis}

The direct cause of tooth loss in periodontitis is excessive resorption of alveolar bone, which supports tooth roots. FR202126, an ATPase inhibitor, inhibited bone resorption in calvaria cultures, which, it was suggested, may offer a novel approach for the treatment of periodontitis [374].
Paget's disease

This disease is characterised by an increase in osteoclast number, resulting in an excess of bone resorption and high bone turnover. Bisphosphonates have been used to treat diseases with excessive bone resorption and high bone turnover, such as Paget's disease. They act by inducing apoptosis of osteoclasts. It has been suggested that nitrogen-containing bisphosphonates block mitochondrial ADP/ATP translocase, which is involved in the induction of apoptosis [375]. P2X7 antagonists are also being considered for the treatment of bone diseases where there is an increase in osteoclasts number such as Paget's disease [366].

\section{Rickets}

Rickets is a bone disorder caused by a vitamin $\mathrm{D}$ and phosphate deficiency. In rachitic rats, induced by the use of synthetic diets, there was a decrease in whole blood ATP and serum phosphorus. Subcutaneous injection of ATP or inorganic phosphate caused an increase in serum phosphorus and blood ATP levels, and it was suggested that the metabolic disturbances in rickets were due to alteration in ATP production [376].

\section{Ossification of the posterior longitudinal ligament of the spine}

This disease is characterised by ectopic bone formation in the spinal ligament, which compresses the spinal cord, resulting in serious neurological damage. It is a common disease in Japanese and other Asian populations and has been treated by spinal cord decompression surgery. Work has shown that extracellular concentrations of ATP in ossification of the posterior longitudinal ligament of the spine (OPLL) cell cultures are significantly higher than those in non-OPLL cultures and $\mathrm{P} 2 \mathrm{Y}_{1}$ receptors are highly expressed in OPLL cells, but only weakly expressed in non-OPLL cells [377]. Furthermore, ATP and mechanical stress raise the mRNA levels of alkaline phosphatase and osteopontin in OPLL cells. These effects were blocked by MRS2179, a selective $\mathrm{P} 2 \mathrm{Y}_{1}$ receptor antagonist. A later study from this group showed that $\mathrm{P} 2 \mathrm{Y}_{1}$ receptor over-expression in OPLL-induced mineralisation leading to ectopic bone formation in the spinal ligament cell of OPLL patients [378].

\section{Rheumatoid arthritis}

RA is a disease of the synovial lining of joints. It is a complex, multi-factorial autoimmune disease and many patients show the presence of rheumatoid factor in their serum. The joints are initially painful, swollen and stiff, but as the disease progresses, the ligaments supporting the joints are damaged and there is erosion of the bone leading to deformity of the joints. Tendon sheaths can also be affected leading to tendon rupture. 
The potential involvement of purinergic signalling in RA was first identified in the 1990s when adenosine concentrations, formed following the breakdown of released ATP, were lower in RA synovial fluid than in osteoarthritis (OA). Thus, the augmentation of adenosine levels was suggested as a treatment of this condition [379]. Compared to the joints from RA patients, higher levels of ATP and 5'-nucleotidase activity were also observed in the synovial fluid from osteoarthritic joints; especially from osteoarthritic patients in whom deposition of calcium-containing crystals was also present [380, 381]. Later, ATP and UTP were claimed to activate calciummobilizing P2U receptors to act synergistically with IL-1 to stimulate $\mathrm{PGE}_{2}$ release from human rheumatoid synovial cells [382].

IL- $1 \beta$ is a proinflammatory cytokine that is thought to play an important role in the progression of RA. ATP, acting via P2X7 receptors, induced significantly higher levels of IL-1 $\beta$ in blood samples from RA patients compared to controls [383]. They suggested that mononuclear cells from these patients were more sensitive to ATP stimulation than those from healthy individuals, perhaps due to genetic polymorphism in the P2X7 gene. A separate study also reported increased IL-1 $\beta$ release in RA patients and these investigators suggested that $\mathrm{P} 2 \mathrm{X} 7$ receptors play a role in the pathogenesis of RA and systemic lupus erythematosus [384]. A recent paper has also shown that the His155Tyr (489C >T) SNP of the $\mathrm{P} 2 \mathrm{X} 7$ receptor gene confers an enhanced function of $\mathrm{P} 2 \mathrm{X} 7$ receptors in immune cells from patients with RA [385]. Human rheumatoid synoviocytes express $\mathrm{P} 2 \mathrm{X} 7$ receptor mRNA and protein; stimulation of which leads to release of the cytokine IL-6, but does not cause pore formation and cell death [386]. The activating protein-1, particularly FosB, appears to be linked to $\mathrm{P} 2 \mathrm{X} 7$ receptors in the control of immune and osteogenic function [387]. In addition, animal models of arthritis have provided evidence that suggests an in vivo role for the P2X7 receptor in the progression of inflammatory disease; P2X7 receptor knockout mice exhibited a reduced incidence and severity of anti-collagen-induced arthritis symptoms [388]. Thus, targeting the $\mathrm{P} 2 \mathrm{X} 7$ receptor could be a promising treatment for RA [172]. Block of P2X7 receptor signalling in the collagen-induced arthritis animal model of RA inhibited peripheral inflammatory tissue destruction and the autoreactive humoral response, supporting the view that P2X7 receptor antagonists may cure inflammatory autoimmune diseases, such as RAs [389]. However, a later study claimed that AZD9056, a P2X7 receptor antagonist, did not appear to be a therapeutically useful target for RA [390]. P2X7 receptor antagonists are also being explored for the treatment of inflammatory pain in joints [391]. A multicentre, double-blind, placebo-controlled clinical trial was launched to see if ATP infusion therapy was effective in patients with RA [392], and later it was claimed that ATP infusions reduced inflammation and disease activity of a patient with RA [393].
Bovine chondrocytes express $\mathrm{P} 2 \mathrm{X} 1$ and $\mathrm{P} 2 \mathrm{X} 3$ receptors, which, following stimulation, lead to release of the inflammatory mediators $\mathrm{NO}$ and $\mathrm{PGE}_{2}$ [303]. Thus, antagonists for these receptors may be potential targets for pathophysiological diseases linked to inflammation and articular cartilage resorption. Patients with RA have increased risk of cardiovascular disorders, and it was shown that there was an enhanced response of platelets to ADP in patients with RA [394].

Sympathetic nerves have proinflammatory effects during the early phase of type II collagen-induced arthritis, probably mediated by cytokines, such as interferon- $\gamma$ released by cells in response to sympathetic cotransmitters [395], and perhaps involving ATP. An important study supported the notion that $\alpha, \beta$-meATP-sensitive P2X (probably P2X3) receptors are present in peripheral nociceptive afferent fibres in the rat knee joint and ATP, levels of which are increased in inflamed and damaged tissues, may be involved in the initiation of nociception and pain [396]. P2X3 receptors were also described on nociceptive sensory fibres in lumber facet joints, from which low back pain can originate [397]. It was also observed that changes in the expression of $\mathrm{P} 2 \mathrm{X} 3$ receptors on isolectin B4-labelled DRG neurons occur after induction of RA [398]. In addition, it has been suggested that P2X3 receptors expressed on trigeminal ganglia play an important role in orofacial pressure pain caused by monoarthritis of the temporomandibular joint [399].

It has been postulated that the nervous system may play a role in the pathogenesis of rheumatic diseases, involving lymphocytes that are recognised to be innervated (see [400]). ATP, released as a cotransmitter from sympathetic nerves, enhanced bradykinin-induced plasma extravasation in the rat knee joint [401]. Intravenous guanethidine, that prevents the release of sympathetic cotransmitters, was shown to be effective in patients with RA [402] and it is possible that this is due to the pro-inflammatory effects of ATP, released as a cotransmitter from sympathetic nerves.

There is abundant evidence demonstrating a role for adenosine in the pathogenesis of RA (see review by Varani et al. [148]). Synovial fluid taken from patients with RA, but not OA, shows increased activity of ADA [403, 404]. An increase in ADA activity was also found in rheumatoid synovial fibroblasts [405]. Consequently, it was suggested that serum ADA may predict disease activity in RA [406]. It has been shown that the ImmuKnow assay may be effective in identifying RA patients at increased risk of infection [407].

2-Chloroadenosine was shown to induce apoptotic cell death of fibroblast-like synoviocytes derived from patients with RA [408]. It was also reported that signalling via the $\mathrm{A}_{2 \mathrm{~A}}$ receptor caused modification of the cytokine milieu in RA [409]. Release of TNF- $\alpha$ by adenosine was also substantially lower in patients with RA compared to control subjects [410]. However, in another study, the symptoms of RA were 
not modified by treatment with the adenosine uptake inhibitor, dipyridamole [411].

Overexpression of $\mathrm{A}_{3}$ receptors was found in peripheral blood mononuclear cells of RA patients; upregulation was induced by inflammatory cytokines controlling the expression of the $\mathrm{A}_{3}$ receptor transcription factor NF-KB [412]. $\mathrm{A}_{3}$ receptors were also found to be expressed at higher levels in the synovium of patients with RA [413]. Increased levels of $\mathrm{A}_{2 \mathrm{~A}}$ and $\mathrm{A}_{3}$ receptors on the lymphocytes and neutrophils of RA patients were also reported, and it was shown that anti-TNF- $\alpha$ normalized $\mathrm{A}_{2 \mathrm{~A}}$ and $\mathrm{A}_{3}$ receptor expression and functionality [414].

Adjuvant-induced monoarthritis is regarded as a useful model for RA and other chronic inflammatory conditions. Spinal cord adenosine receptor activation inhibits inflammation and joint destruction in rat adjuvant-induced arthritis [415]. In a later paper from this group, they showed that $A_{1}$ receptor agonists reduced $c-f o s$ and astrocyte activation in dorsal horn of rats with induced RA [416]. Later, an $\mathrm{A}_{3}$ specific agonist was shown to prevent bone resorption in this model [417]. ATP, perhaps working via $\mathrm{A}_{2}$ receptors, also substantially reduces joint injury [418]. The $A_{3}$ receptor agonist, CF502, reduced expression levels of protein kinases in fibroblast-like synoviocytes from RA patients and in adjuvant-induced arthritic rats [419]. Furthermore, block of the nucleoside transporter inhibited disease progression in rat RA models [420].

An early study reported the suppression of zymosaninduced inflammatory arthritis by intraperitoneal administration of adenosine [421]. Later evidence from a phase II clinical trial has suggested that $A_{3}$ receptor agonists could be used to treat RA [422-424]. Additionally, an agonist of the $A_{2 A}$ receptor, CGS 21680, reduced progression of murine type II collagen-induced arthritis [425] and activation of $\mathrm{A}_{2 \mathrm{~A}}$ receptors on immune cells by a CD73-dependent prodrug decreased joint inflammation in experimental RA [426]. A phosphorylated $\mathrm{A}_{2 \mathrm{~A}}$ receptor agonist, Chet-AMP, has been shown to have anti-inflammatory activity in collagen-induced arthritis, by acting locally on immune cells invading inflamed tissue [427]. A recent study has examined how effective $\mathrm{A}_{2 \mathrm{~A}}$ receptor agonists are for the treatment of RA in relation to different pharmacological treatments and shown that they ameliorate adjuvant-induced arthritis in rats [428].

Methotrexate (MTX) is widely used for the treatment of RA. In human inflammatory joint disease, the modulation of orphan nuclear receptor expression by MTX involved $\mathrm{A}_{2 \mathrm{~A}}$ receptor-mediated responses [429]. Furthermore, MTXinduced suppression of osteoclastic bone destruction in adjuvant-induced arthritis was abolished by extracellular adenosine, acting via $\mathrm{A}_{2 \mathrm{~B}}$ receptors [430]. Gene-gene interactions in adenosine biosynthesis pathways have been shown to affect MTX efficacy and tolerability in RA [431]. Studies of polymorphisms in genes contributing to adenosine release in
RA patients treated with MTX led to the conclusion that genotyping may help in the identification of patients who would benefit most from MTX treatment [432].

Anti-TNF- $\alpha$ is also used as a treatment for RA, but it increases the risk of tuberculosis (TB) reactivation. Serum ADA levels increase in TB patients, and it was suggested that elevated ADA levels could be used for diagnosis of TB in patients being treated with anti-TNF- $\alpha$ [433]. Differences between ADA levels in joint effusion and serum of patients with RA and OA have been observed, and it was concluded that ADA assay could be a sensitive and specific test for the rapid diagnosis of rheumatoid effusions [434].

\section{Osteoarthritis}

OA is a degenerative disease of the joints resulting from wear of the articular cartilage, which leads to (or may even result from) secondary changes in the underlying subchondral bone. OA can be primary or secondary to abnormal load to the joint or from trauma, infection or ageing. It can be recognised by loss of cartilage and the presence of osteophytes, osteosclerosis and cysts in the bone. The pain from OA appears to be due largely to inflammation.

At present, information regarding the role of $\mathrm{P} 2$ receptor signalling in the pathogenesis of $\mathrm{OA}$ is limited. In guinea pig knee OA, a heightened generation of NO is related to the depletion of ATP in chondrocytes [435]. It was suggested that the elevation of the ecto-nucleotidase NPP1 and its product $\mathrm{PP}_{\mathrm{i}}$, which directly stimulates chondrocalcinosis, may be driven by chondrocyte ATP depletion.

ATP has been shown to directly contribute to pathologic mineralisation in articular cartilage, and thus, P2 receptor antagonists may lead to effective therapies for crystalassociated arthritis [436]. Levels of ATP in the synovial fluid are also related to the pain intensity in patients with OA of the knee [437]. Different polymorphic variants of the P2X7 receptor have been associated with high or reduced periprosthetic osteolysis in the long-term complication of the total hip arthroplasty [438].

Adenosine signalling also appears to be involved in OA. Adenosine excites nociceptive afferents of the rat knee joint via $A_{1}$ receptors [439]. A study using the murine osteoarthritic STR/ort strain showed that increased adenosine production may induce chondrocyte apoptosis and play a role in OA in the tibial cartilage [440]. Adenosine, produced after breakdown of ATP released from chondrocytes, plays a role in the response to tissue damage in arthritic conditions and inhibition of adenosine kinase attenuates IL-1- and lipopolysaccharide (LPS)-induced changes in articular cartilage in arthritis [441]. In addition, $\mathrm{A}_{2 \mathrm{~A}}$ receptors are involved in the regulation of LPS-induced IL-6 release, implying a regulatory role for adenosine receptors in the control of inflammation and osteoclastogenesis [442]. 
Synovial fibroblasts can contribute to the development of OA by the secretion of pro-inflammatory mediators. Electromagnetic field stimulation led to up-regulation of $\mathrm{A}_{2 \mathrm{~A}}$ receptors in synovial fibroblasts and it was suggested that adenosine, acting through both $\mathrm{A}_{1}$ and $\mathrm{A}_{2 \mathrm{~A}}$ receptors, had anti-inflammatory activity to control joint inflammation [443]. $\mathrm{A}_{2 \mathrm{~A}}$ and $\mathrm{A}_{3}$ receptor agonists have been shown to modulate $\mathrm{PGE}_{2}$ and cytokine release in human osteoarthritic fibroblasts [444]. Adenosine receptors also regulate inflammatory responses in human synoviocytes [445].

$\mathrm{A}_{2 \mathrm{~A}}$ receptor agonists have been used to reduce joint destruction due to septic arthritis [446] and they may reduce the destructive effects of polyethylene wear debris and prevent joint prosthesis loosening [447].

\section{Bone cancer and multiple myeloma}

Bone metastases, the most common type of metastases for patients with breast and prostate cancer, can result in significant bone loss, fractures, pain, hypercalcemia and spinal cord compression. Skeletal metastases have been radiographically classified as osteoblastic or osteolytic. Osteoblastic lesions are characteristic of prostate cancer, while in breast cancer, osteolytic lesions are found in $80 \%$ of patients with stage IV metastatic disease. Complex cross-talk between tumour cells and the bone microenvironment promotes an active cycle of bone metastases through multiple extracellular factors, probably also including nucleotides (see [448, 449]).

The involvement of purinergic signalling in bone cancer was first noted in the 1990 s when P2U (i.e. $\mathrm{P}_{2} \mathrm{Y}_{2} / \mathrm{P}_{2} \mathrm{Y}_{4}$ ) receptors were cloned and sequenced from osteoclastoma, a rare bone tumour caused by a malignant proliferation of osteoclasts [156]. The expression of $\mathrm{P}_{2} \mathrm{Y}_{2}$ receptor transcripts from human osteoclasts from giant cell tumour of bone was subsequently reported [259]. Butyl benzyl phthalate, which is an endocrine disruptor that is known to interfere with mammalian ion channel receptors, suppressed ATP-induced cell proliferation mediated by $\mathrm{P} 2 \mathrm{X}$ receptors in human osteosarcoma HOS cells [450]. Early work also highlighted that ATP was useful for purging residual tumour cells in autologous bone marrow transplantation [451]. Furthermore, APT102, a novel form of human apyrase/ADPase, works together with aspirin to disrupt bone metastasis in mice [452]. It is conceivable that ATP released from tumour cells could further stimulate osteoclast formation and activity [12], thus contributing to the so-called vicious cycle of bone destruction that commonly occurs around tumour metastases.

Bisphosphonates, drugs routinely used to treat osteoporosis, have been used for the treatment of bone cancer. The antitumour effects of these drugs are not clear but could involve apoptosis induced by the ATP analogue ApppI produced by nitrogen-containing bisphosphonates [453, 454].
There is compelling evidence that purinergic signalling is involved in cancer pain. Radiation therapy has been used to relieve bone pain and it was suggested that it may be related to the $\mathrm{Ca}^{2+}$-signalling cascade, mediated at least in part by $\mathrm{P} 2 \mathrm{X} 6$ receptors [455]. Experiments using a murine model of cancer pain demonstrated increased expression of $\mathrm{P} 2 \mathrm{X} 3$ receptors on calcitonin gene-related peptide immunoreactive epidermal nerve fibres during tumour growth, suggesting a role for ATP in cancer-related pain [456]. In an impressive study, systemic blockade of $\mathrm{P} 2 \mathrm{X} 3$ and $\mathrm{P} 2 \mathrm{X} 2 / 3$ receptors with AF-353 was shown to substantially attenuate bone cancer pain behaviour in rats [457]. Chronic administration of the selective P2X3 and P2X2/3 receptor antagonist, A-317491, was also shown to transiently attenuate cancer-induced bone pain in mice in the early stages, but not in the later stages [458]. Perhaps the differences between the two stages can be explained by the fact that A-317491 has high plasma protein binding and limited CNS penetration, while AF-353 has low plasma protein binding and good CNS penetration, suggesting that there may be a central component of action against bone cancer pain. Functional up-regulation of $\mathrm{P} 2 \mathrm{X} 3$ receptors has also been described in DRG in a rat model of bone cancer pain [459].

P2X7 receptor knockout mice are susceptible to bone cancer pain and had an earlier onset of pain-related behaviours compared to cancer-bearing, wild-type mice [460]. P2X7 receptor activation also induces cell death and cell surface $\mathrm{CD} 23$ (the low affinity IgE receptor) shedding from lymphocytes in human RPMI 8226 multiple myeloma cells [461]. A recent paper has presented evidence that $\mathrm{P}_{2} \mathrm{Y}_{1}$ receptor signalling in the spinal cord and DRG may mediate bone cancer pain through the ERK pathway [462].

Multiple myeloma is a cancer of plasma cells but is often characterised by osteolytic bone lesions, primarily caused by increased osteoclast activity. It has been suggested that $A_{2}$ receptors may be useful targets for the treatment and prevention of multiple myeloma-induced bone disease since activation of $\mathrm{A}_{2 \mathrm{~A}}$ receptors diminishes osteoclast function, while activation of $\mathrm{A}_{2 \mathrm{~B}}$ receptors promotes osteoblast differentiation [463].

8-Amino-adenosine has also been proposed as a potential therapeutic agent for the treatment of multiple myeloma [464].

\section{Severe combined immunodeficiency (SCID)}

Genetic defects in the ADA gene are a major cause of SCID. Lack of ADA causes accumulation of adenosine. About a half of early-onset ADA-deficient patients exhibited bone defects due to decreased osteoclastogenesis and an intrinsic defect of osteoblasts function with subsequent low bone formation [465]. Additionally, they showed that the bone marrow microenvironment of ADA-deficient mice displayed a reduced capacity to support hematopoiesis and that treatment of ADAdeficient mice with enzyme replacement, gene therapy or 
bone marrow transplantation resulted in full recovery. Gene therapy with ADA-transduced hematopoietic stem cells also improved children's growth.

\section{Desbuquois dysplasia}

This is an autosomal-recessive chondrodysplasia, characterised by severe prenatal and postnatal growth retardation, joint laxity, short extremities and progressive scoliosis. Calciumactivated nucleotidase 1 gene mutations have been identified in nine families with Desbuquois type 1, a gene that hydrolyses UDP followed by guanosine diphosphate and UTP [466].

\section{Dwarfism (achondroplasia)}

This is a congenital skeletal dysplasia due to a mutation in the gene that encodes the fibroblast growth factor receptor type 3, which acts through the MAPK cascade. Diadenosine tetraphosphate, $\mathrm{Ap}_{4} \mathrm{~A}$, diminished the expression of the achondroplasic FGFR3 receptor, stimulating FGFR3 receptor degradation [467]. In a later paper from this group, it was shown that $\mathrm{P} 2 \mathrm{Y}_{1}, \mathrm{P} 2 \mathrm{Y}_{2}, \mathrm{P}_{2} \mathrm{Y}_{6}$ and $\mathrm{P} 2 \mathrm{Y}_{11}$ receptors were expressed by achondroplasic chondrocytes and that $\mathrm{Ap}_{4} \mathrm{~A}$ was acting via these P2Y receptors [468]. In a more recent study, they showed that $\mathrm{Ap}_{4} \mathrm{~A}$ reversed the morphological changes triggered by FGF9 and restored the chloride efflux, providing further evidence for the therapeutic potential of this dinucleotide in the treatment of dwarfism [469].

\section{Concluding remarks}

Current evidence shows that purinergic signalling exerts complex local effects on the function of musculoskeletal cells. The effects of this signalling system are influenced by a number of factors including the receptor subtype, the extracellular nucleotides present locally and the expression of ecto-nucleotidases. In some cases, there appears to be a degree of redundancy present with several receptor subtypes mediating similar functional effects. Purinergic signalling has now been implicated in many disorders associated with the musculoskeletal system and thus presents many potential targets for future therapies. It should be noted that, given the ubiquitous nature of these receptors, selectively targeting specific cell types may prove challenging. In this respect, targeting the ecto-nucleotidases responsible for extracellular nucleotide breakdown or ATP transport inhibitors could also prove beneficial.

Acknowledgments The authors are very grateful to Dr. Gillian E. Knight for her excellent editorial assistance during the preparation of this review article. Isabel R. Orriss and Timothy R. Arnett are very grateful to Arthritis Research UK for financial support.

\section{References}

1. Buchthal F, Folkow B (1944) Close arterial injection of adenosine triphosphate and inorganic triphosphate into frog muscle. Acta Physiol Scand 8:312-316

2. Buchthal F, Folkow B (1948) Interaction between acetylcholine and adenosine triphosphate in normal, curarised and denervated muscle. Acta Physiol Scand 15:150-160

3. Dowdall MJ, Boyne AF, Whittaker VP (1974) Adenosine triphosphate. A constituent of cholinergic synaptic vesicles. Biochem J 140:1-12

4. Zimmermann H (1982) Co-existence of adenosine 5'-triphosphate and acetylcholine in the electromotor synapse. In: Cuello AC (ed) Co-transmission. Macmillan, London, pp 243-259

5. Silinsky EM, Hubbard JI (1973) Release of ATP from rat motor nerve terminals. Nature 243:404-405

6. Silinsky EM (1975) On the association between transmitter secretion and the release of adenine nucleotides from mammalian motor nerve terminals. J Physiol 247:145-162

7. Kumagai H, Sakamoto H, Guggino S, Filburn CR, Sacktor B (1989) Neurotransmitter regulation of cytosolic calcium in osteoblast-like bone cells. Calcif Tissue Int 45:251-254

8. Kumagai H, Sacktor B, Filburn CR (1991) Purinergic regulation of cytosolic calcium and phosphoinositide metabolism in rat osteoblast-like osteosarcoma cells. J Bone Miner Res 6:697-708

9. Reimer WJ, Dixon SJ (1992) Extracellular nucleotides elevate $\left[\mathrm{Ca}^{2+}\right]_{\mathrm{i}}$ in rat osteoblastic cells by interaction with two receptor subtypes. Am J Physiol 263:C1040-C1048

10. Yu H, Ferrier J (1993) ATP induces an intracellular calcium pulse in osteoclasts. Biochem Biophys Res Commun 191:357-363

11. Hoebertz A, Mahendran S, Burnstock G, Arnett TR (2002) ATP and UTP at low concentrations strongly inhibit bone formation by osteoblasts: a novel role for the $\mathrm{P}_{2} \mathrm{Y}_{2}$ receptor in bone remodelling. Journal of Cellular Biochemistry 86:413-419

12. Morrison MS, Turin L, King BF, Burnstock G, Arnett TR (1998) ATP is a potent stimulator of the activation and formation of rodent osteoclasts. J Physiol 511:495-500

13. Burnstock G, Verkhratsky A (2012) Purinergic signalling and the nervous system. Springer, Heidelberg, pp 1-715

14. Wells DG, Zawisa MJ, Hume RI (1995) Changes in responsiveness to extracellular ATP in chick skeletal muscle during development and upon denervation. Dev Biol 172:585-590

15. Silinsky EM, Redman RS (1996) Synchronous release of ATP and neurotransmitter within milliseconds of a motor nerve impulse in the frog. J Physiol 492:815-822

16. Sokolova E, Grishin S, Shakirzyanova A, Talantova M, Giniatullin R (2003) Distinct receptors and different transduction mechanisms for ATP and adenosine at the frog motor nerve endings. Eur J Neurosci 18:1254-1264

17. Tung EK, Choi RC, Siow NL, Jiang JX, Ling KK, Simon J, Barnard EA, Tsim KW (2004) $\mathrm{P}_{2} \mathrm{Y}_{2}$ receptor activation regulates the expression of acetylcholinesterase and acetylcholine receptor genes at vertebrate neuromuscular junctions. Mol Pharmacol 66:794-806

18. Giniatullin AR, Grishin SN, Sharifullina ER, Petrov AM, Zefirov AL, Giniatullin RA (2005) Reactive oxygen species contribute to the presynaptic action of extracellular ATP at the frog neuromuscular junction. J Physiol 565:229-242

19. Grishin S, Shakirzyanova A, Giniatullin A, Afzalov R, Giniatullin R (2005) Mechanisms of ATP action on motor nerve terminals at the frog neuromuscular junction. Eur J Neurosci 21:1271-1279

20. Ahdut-Hacohen R, Meiri H, Rahamimoff R (2006) ATP dependence of the non-specific ion channel in Torpedo synaptic vesicles. Neuroreport 17:653-656

21. Massé K, Eason R, Bhamra S, Dale N, Jones EA (2006) Comparative genomic and expression analysis of the conserved NTPDase gene family in Xenopus. Genomics 87:366-381 
22. Ginsborg BL, Hirst GDS (1972) The effect of adenosine on the release of the transmitter from the phrenic nerve of the rat. J Physiol 224:629-645

23. Ribeiro JA, Walker J (1975) The effects of adenosine triphosphate and adenosine diphosphate on transmission at the rat and frog neuromuscular junctions. Br J Pharmacol 54:213-218

24. Silinsky EM (1984) On the mechanism by which adenosine receptor activation inhibits the release of acetylcholine from motor nerve endings. J Physiol 346:243-256

25. Silinsky EM (2008) Selective disruption of the mammalian secretory apparatus enhances or eliminates calcium current modulation in nerve endings. Proc Natl Acad Sci U S A 105:6427-6432

26. Ribeiro JA, Sebastiao AM (1987) On the role, inactivation and origin of endogenous adenosine at the frog neuromuscular junction. J Physiol 384:571-585

27. Smith DO (1991) Sources of adenosine released during neuromuscular transmission in the rat. J Physiol 432:343-354

28. Barroso A, Oliveira L, Campesatto-Mella E, Silva C, Timóteo MA, Magãlhaes-Cardoso MT, Alves-do-Prado W, Correia-de-Sá P (2007) L-citrulline inhibits $\left[{ }^{3} \mathrm{H}\right]$ acetylcholine release from rat motor nerve terminals by increasing adenosine outflow and activation of A1 receptors. Br J Pharmacol 151:541-550

29. Ribeiro JA (1977) Potentiation of postjunctional cholinergic sensitivity of rat diaphragm muscle by high-energy-phosphate adenine nucleotides. J Membr Biol 33:401-402

30. Kolb HA, Wakelam MJO (1983) Transmitter-like action of ATP on patched membranes of cultured myoblasts and myotubes. Nature 303:621-623

31. Lu Z, Smith DO (1991) Adenosine 5'-triphosphate increases acetylcholine channel opening frequency in rat skeletal muscle. J Physiol 436:45-56

32. Henning RH (1997) Purinoceptors in neuromuscular transmission. Pharmacol Ther 74:115-128

33. Heilbronn E, Eriksson H (1998) Second messengers mobilized by ATP and ACh in the myotube/muscle fiber. In: Sellin LC, Libelius R, Thesleff S (eds) Neuromuscular junction. Elsevier, Amsterdam, pp 395-404

34. Silinsky EM, Hirsh JK, Searl TJ, Redman RS, Watanabe M (1999) Quantal ATP release from motor nerve endings and its role in neurally mediated depression. Prog Brain Res 120:145-158

35. Dowdall MJ (1975) Synthesis and storage of acetylcholine in cholinergic nerve terminals. In: Berl S, Clarke DD, Schneider D (eds) Metabolic compartmentation and neurotransmission. Plenum, New York, pp 585-607

36. Schweitzer E (1987) Coordinated release of ATP and ACh from cholinergic synaptosomes and its inhibition by calmodulin antagonists. J Neurosci 7:2948-2956

37. Correia-de-Sá P, Timóteo MA, Ribeiro JA (1996) Presynaptic $A_{1}$ inhibitory $/ \mathrm{A}_{2 \mathrm{~A}}$ facilitatory adenosine receptor activation balance depends on motor nerve stimulation paradigm at the rat hemidiaphragm. J Neurophysiol 76:3910-3919

38. Pousinha PA, Correia AM, Sebastião AM, Ribeiro JA (2010) Predominance of adenosine excitatory over inhibitory effects on transmission at the neuromuscular junction of infant rats. J Pharmacol Exp Ther 332:153-163

39. Salgado AI, Cunha RA, Ribeiro JA (2000) Facilitation by $P_{2}$ receptor activation of acetylcholine release from rat motor nerve terminals: interaction with presynaptic nicotinic receptors. Brain Res 877:245-250

40. Garcia N, Priego M, Obis T, Santafe MM, Tomàs M, Besalduch N, Lanuza MA, Tomàs $J$ (2013) Adenosine $A_{1}$ and $A_{2 A}$ receptormediated modulation of acetylcholine release in the mice neuromuscular junction. Eur J Neurosci Epub ahead of print

41. Moores TS, Hasdemir B, Vega-Riveroll L, Deuchars J, Parson SH (2005) Properties of presynaptic $\mathrm{P}_{2} \mathrm{X}_{7}$-like receptors at the neuromuscular junction. Brain Res 1034:40-50
42. Parson SH, Iqbal R (2000) Mouse motor nerve terminals release synaptic vesicles following activation of $\mathrm{P} 2 \mathrm{X}_{7}$ receptors. J Physiol 528:60P

43. Galkin AV, Giniatullin RA, Mukhtarov MR, Svandova I, Grishin SN, Vyskocil F (2001) ATP but not adenosine inhibits nonquantal acetylcholine release at the mouse neuromuscular junction. Eur J Neurosci 13:2047-2053

44. De Lorenzo S, Veggetti M, Muchnik S, Losavio A (2006) Presynaptic inhibition of spontaneous acetylcholine release mediated by $\mathrm{P} 2 \mathrm{Y}$ receptors at the mouse neuromuscular junction. Neuroscience $142: 71-85$

45. Veggetti M, Muchnik S, Losavio A (2008) Effect of purines on calcium-independent acetylcholine release at the mouse neuromuscular junction. Neuroscience 154:1324-1336

46. Malomouzh AI, Nikolsky EE, Vyskocil F (2011) Purine P2Y receptors in ATP-mediated regulation of non-quantal acetylcholine release from motor nerve endings of rat diaphragm. Neurosci Res 71:219-225

47. Su TR, Hung YS, Huang SS, Su HH, Su CC, Hsiao G, Chen YH, Lin MJ (2011) Study of the reversal effect of NF449 on neuromuscular blockade induced by d-tubocurarine. Life Sci 88:1039-1046

48. Naumenko NV, Uzinskaya KV, Shakirzyanova AV, Urazaev AK, Zefirov AL (2009) Adenosine triphosphoric acid as a factor of nervous regulation of $\mathrm{Na}^{+} / \mathrm{K}^{+} / 2 \mathrm{Cl}^{-}$cotransport in rat skeletal muscle fibers. Bull Exp Biol Med 147:583-586

49. Ryten M, Hoebertz A, Burnstock G (2001) Sequential expression of three receptor subtypes for extracellular ATP in developing rat skeletal muscle. Dev Dyn 221:331-341

50. Khakh BS, Zhou X, Sydes J, Galligan JJ, Lester HA (2000) Statedependent cross-inhibition between transmitter-gated cation channels. Nature 406:405-410

51. Ryten M, Koshi R, Knight GE, Turmaine M, Dunn PM, Cockayne DA, Ford APDW, Burnstock G (2007) Abnormalities in neuromuscular junction structure and skeletal muscle function in mice lacking the $\mathrm{P} 2 \mathrm{X}_{2}$ nucleotide receptor. Neuroscience 148:700-711

52. Jia M, Li MX, Fields RD, Nelson PG (2007) Extracellular ATP in activity-dependent remodeling of the neuromuscular junction. Dev Neurobiol 67:924-932

53. Light AR, Hughen RW, Zhang J, Rainier J, Liu Z, Lee J (2008) Dorsal root ganglion neurons innervating skeletal muscle respond to physiological combinations of protons, ATP, and lactate mediated by ASIC, P2X, and TRPV1. J Neurophysiol 100:1184-1201

54. McCord JL, Tsuchimochi H, Kaufman MP (2010) P2X2/3 and $\mathrm{P} 2 \mathrm{X} 3$ receptors contribute to the metaboreceptor component of the exercise pressor reflex. J Appl Physiol 109:1416-1423

55. Schoenberg M (1989) Effect of adenosine triphosphate analogues on skeletal muscle fibers in rigor. Biophys J 56:33-41

56. Buvinic S, Almarza G, Bustamante M, Casas M, López J, Riquelme M, Sáez JC, Huidobro-Toro JP, Jaimovich E (2009) ATP released by electrical stimuli elicits calcium transients and gene expression in skeletal muscle. J Biol Chem 284:34490-34505

57. Mortensen SP, González-Alonso J, Nielsen JJ, Saltin B, Hellsten Y (2009) Muscle interstitial ATP and norepinephrine concentrations in the human leg during exercise and ATP infusion. J Appl Physiol 107:1757-1762

58. Tu J, Lu L, Cai W, Ballard HJ (2012) cAMP/protein kinase A activates cystic fibrosis transmembrane conductance regulator for ATP release from rat skeletal muscle during low $\mathrm{pH}$ or contractions. PLoS One 7:e50157

59. Keresztes M, Häggblad J, Heilbronn E (1991) Basal and ATPstimulated phosphoinositol metabolism in fusing rat skeletal muscle cells in culture. Exp Cell Res 196:362-364

60. Allard B, Lazdunski M (1992) Nucleotide diphosphates activate the ATP-sensitive potassium channel in mouse skeletal muscle. Pflugers Arch 422:185-192 
61. Ayyanathan K, Webbs TE, Sandhu AK, Athwal RS, Barnard EA, Kunapuli SP (1996) Cloning and chromosomal localization of the human P2Y1 purinoceptor. Biochem Biophys Res Commun 218: 783-788

62. Urano T, Nishimori H, Han H, Furuhata T, Kimura Y, Nakamura Y, Tokino T (1997) Cloning of P2XM, a novel human P2X receptor gene regulated by $\mathrm{p} 53$. Cancer Res 57:3281-3287

63. Bo X, Schoepfer R, Burnstock G (2000) Molecular cloning and characterization of a novel ATP P2X receptor subtype from embryonic chick skeletal muscle. J Biol Chem 275:14401-14407

64. Ruppelt A, Liang BT, Soto F (1999) Cloning, functional characterization and developmental expression of a $\mathrm{P} 2 \mathrm{X}$ receptor from chick embryo. Prog Brain Res 120:81-90

65. Ruppelt A, Ma W, Borchardt K, Silberberg SD, Soto F (2001) Genomic structure, developmental distribution and functional properties of the chicken $\mathrm{P}_{2} \mathrm{X}_{5}$ receptor. J Neurochem 77:1256-1265

66. Csernoch L, Cseri J, Mallouk N, Kovács L (2000) ATP-induced changes of intracellular calcium concentration in human skeletal muscle fibres in culture. J Physiol 526:30P-31P

67. Meyer MP, Gröschel-Stewart U, Robson T, Burnstock G (1999) Expression of two ATP-gated ion channels, $\mathrm{P} 2 \mathrm{X}_{5}$ and $\mathrm{P} 2 \mathrm{X}_{6}$, in developing chick skeletal muscle. Dev Dyn 216:442-449

68. Soto F, Krause U, Borchardt K, Ruppelt A (2003) Cloning, tissue distribution and functional characterization of the chicken $\mathrm{P} 2 \mathrm{X}_{1}$ receptor. FEBS Lett 533:54-58

69. Sandona D, Danieli-Betto D, Germinario E, Biral D, Martinello T, Lioy A, Tarricone E, Gastaldello S, Betto R (2005) The T-tubule membrane ATP-operated $\mathrm{P}_{2} \mathrm{X}_{4}$ receptor influences contractility of skeletal muscle. FASEB J 19:1184-1186

70. Banachewicz W, Suplat D, Krzeminski P, Pomorski P, Baranska J (2005) P2 nucleotide receptors on C2C12 satellite cells. Purinergic Signal 1:249-257

71. Rassendren F, Buell GN, Virginio C, Collo G, North RA, Surprenant A (1997) The permeabilizing ATP receptor, P2X $X_{7}$. Cloning and expression of a human cDNA. J Biol Chem 272:5482-5486

72. Ryten M, Dunn PM, Neary JT, Burnstock G (2002) ATP regulates the differentiation of mammalian skeletal muscle by activation of a P2X ${ }_{5}$ receptor on satellite cells. J Cell Biol 158:345-355

73. Deli T, Szappanos H, Szigeti GP, Cseri J, Kovacs L, Csernoch L (2007) Contribution from P2X and P2Y purinoreceptors to ATPevoked changes in intracellular calcium concentration on cultured myotubes. Pflugers Arch 453:519-529

74. Henning RH, Duin M, Den Hertog A, Nelemans A (1993) Characterization of P2-purinoceptor mediated cyclic AMP formation in mouse C2C12 myotubes. Br J Pharmacol 110:133-138

75. Cheung K-K, Ryten M, Burnstock G (2003) Abundant and dynamic expression of $\mathrm{G}$ protein-coupled $\mathrm{P} 2 \mathrm{Y}$ receptors in mammalian development. Dev Dyn 228:254-266

76. Parr CE, Sullivan DM, Paradiso AM, Lazarowski ER, Burch LH, Olsen JC, Erb L, Weisman GA, Boucher RC, Turner JT (1994) Cloning and expression of a human $\mathrm{P}_{2 \mathrm{U}}$ nucleotide receptor, a target for cystic fibrosis pharmacotherapy. Proc Natl Acad Sci USA 91:3275-3279

77. Janssens R, Communi D, Pirotton S, Samson M, Parmentier M, Boeynaems JM (1996) Cloning and tissue distribution of the human P2Y1 receptor. Biochem Biophys Res Commun 221:588-593

78. Cseri J, Szappanos H, Szigeti GP, Csernatony Z, Kovacs L, Csernoch L (2002) A purinergic signal transduction pathway in mammalian skeletal muscle cells in culture. Pflugers Arch 443: 731-738

79. Pietrangelo T, Fioretti B, Mancinelli R, Catacuzzeno L, Franciolini F, Fanò G, Fulle S (2006) Extracellular guanosine-5'-triphosphate modulates myogenesis via intermediate $\mathrm{Ca}^{2+}$-activated $\mathrm{K}^{+}$currents in C2C12 mouse cells. J Physiol 572:721-733

80. Araya R, Riquelme MA, Brandan E, Sáez JC (2004) The formation of skeletal muscle myotubes requires functional membrane receptors activated by extracellular ATP. Brain Res Brain Res Rev 47:174-188

81. Teplov AY, Grishin SN, Zefirov AL, Ziganshin AU (2006) Role of protein kinase $\mathrm{C}$ in the effect of ATP on contractile function of the isolated strip from mouse diaphragm. Bull Exp Biol Med 141:407409

82. Deli T, Tóth BI, Czifra G, Szappanos H, Bíró T, Csernoch L (2006) Differences in purinergic and voltage-dependent signalling during protein kinase $\mathrm{C} \alpha$ overexpression- and culturing-induced differentiation of C2C12 myoblasts. J Muscle Res Cell Motil 27:617-630

83. Stiber JA, Tabatabaei N, Hawkins AF, Hawke T, Worley PF, Williams RS, Rosenberg P (2005) Homer modulates NFAT-dependent signaling during muscle differentiation. Dev Biol 287:213-224

84. Blaauw B, Del Piccolo P, Rodriguez L, Gonzalez VHH, Agatea L, Solagna F, Mammano F, Pozzan T, Schiaffino S (2012) No evidence for inositol 1,4,5-trisphosphate-dependent $\mathrm{Ca}^{2+}$ release in isolated fibers of adult mouse skeletal muscle. J Gen Physiol 140:235-241

85. May C, Weigl L, Karel A, Hohenegger M (2006) Extracellular ATP activates ERK1/ERK2 via a metabotropic $\mathrm{P}_{2} \mathrm{Y}_{1}$ receptor in a $\mathrm{Ca}^{2+}$ independent manner in differentiated human skeletal muscle cells. Biochem Pharmacol 71:1497-1509

86. Choi RC, Siow NL, Cheng AW, Ling KK, Tung EK, Simon J, Barnard EA, Tsim KW (2003) ATP acts via P2Y1 receptors to stimulate acetylcholinesterase and acetylcholine receptor expression: transduction and transcription control. J Neurosci 23:44454456

87. Voss AA (2009) Extracellular ATP inhibits chloride channels in mature mammalian skeletal muscle by activating $\mathrm{P}_{2} \mathrm{Y}_{1}$ receptors. J Physiol 587:5739-5752

88. Walas H, Juel C (2012) Purinergic activation of rat skeletal muscle membranes increases $\mathrm{Vmax}$ and $\mathrm{Na}+$ affinity of the $\mathrm{Na}$, K-ATPase and phosphorylates phospholemman and $\alpha 1$ subunits. Pflugers Arch 463:319-326

89. Broch-Lips M, Pedersen TH, Nielsen OB (2010) Effect of purinergic receptor activation on $\mathrm{Na}^{+}-\mathrm{K}^{+}$pump activity, excitability, and function in depolarized skeletal muscle. Am J Physiol Cell Physiol 298:C1438-C1444

90. Rathmacher JA, Fuller JC Jr, Baier SM, Abumrad NN, Angus HF, Sharp RL (2012) Adenosine-5'-triphosphate (ATP) supplementation improves low peak muscle torque and torque fatigue during repeated high intensity exercise sets. J Int Soc Sports Nutr 9:48

91. Germinario E, Esposito A, Midrio M, Peron S, Palade PT, Betto R, Danieli-Betto D (2008) High-frequency fatigue of skeletal muscle: role of extracellular $\mathrm{Ca}^{2+}$. Eur J Appl Physiol 104:445-453

92. Cea LA, Riquelme MA, Cisterna BA, Puebla C, Vega JL, Rovegno M, Sáez JC (2012) Connexin- and pannexin-based channels in normal skeletal muscles and their possible role in muscle atrophy. J Membr Biol 245:423-436

93. Osorio-Fuentealba C, Contreras-Ferrat AE, Altamirano F, Espinosa A, Li Q, Niu W, Lavandero S, Klip A, Jaimovich E (2013) Electrical stimuli release ATP to increase GLUT4 translocation and glucose uptake via PI3K $\gamma$-Akt-AS160 in skeletal muscle cells. Diabetes 62:1519-1526

94. Jaimovich E, Bustamante M, Fernández R, Buvinic S (2011) ATP released by electrical stimulation of myotubes triggers IL6 expression and increases $\mathrm{STAT}_{3}$ activity. FASEB J 25:1105.20

95. Taguchi T, Kozaki Y, Katanosaka K, Mizumura K (2008) Compression-induced ATP release from rat skeletal muscle with and without lengthening contraction. Neurosci Lett 434:277-281

96. Martinello T, Baldoin MC, Morbiato L, Paganin M, Tarricone E, Schiavo G, Bianchini E, Sandona D, Betto R (2011) Extracellular ATP signaling during differentiation of $\mathrm{C} 2 \mathrm{C} 12$ skeletal muscle cells: role in proliferation. Mol Cell Biochem 351:183-196

97. Sciancalepore M, Luin E, Parato G, Ren E, Giniatullin R, Fabbretti E, Lorenzon P (2012) Reactive oxygen species contribute to the 
promotion of the ATP-mediated proliferation of mouse skeletal myoblasts. Free Radic Biol Med 53:1392-1398

98. Li J, Sinoway LI (2002) ATP stimulates chemically sensitive and sensitizes mechanically sensitive afferents. Am J Physiol Heart Circ Physiol 283:H2636-H2643

99. Li J, King NC, Sinoway LI (2003) ATP concentrations and muscle tension increase linearly with muscle contraction. J Appl Physiol 95:577-583

100. Laver DR, Lenz GK, Lamb GD (2001) Regulation of the calcium release channel from rabbit skeletal muscle by the nucleotides ATP, AMP, IMP and adenosine. J Physiol 537:763-778

101. Wolner I, Kassack MU, Ullmann H, Karel A, Hohenegger M (2005) Use-dependent inhibition of the skeletal muscle ryanodine receptor by the suramin analogue NF676. Br J Pharmacol 146:525533

102. Dias JM, Vogel PD (2009) Effects of small molecule modulators on ATP binding to skeletal ryanodine receptor. Protein J 28: 240-246

103. Szigeti GP, Szappanos H, Deli T, Cseri J, Kovács L, Csernoch L (2007) Differentiation-dependent alterations in the extracellular ATP-evoked calcium fluxes of cultured skeletal muscle cells from mice. Pflugers Arch 453:509-518

104. Choo HJ, Kim BW, Kwon OB, Lee CS, Choi JS, Ko YG (2008) Secretion of adenylate kinase 1 is required for extracellular ATP synthesis in C2C12 myotubes. Exp Mol Med 40:220-228

105. Rigault C, Bernard A, Georges B, Kandel A, Pfützner E, Le Borgne F, Demarquoy J (2008) Extracellular ATP increases L-carnitine transport and content in C2C12 cells. Pharmacology 81:246-250

106. Warren GL, Hulderman T, Liston A, Simeonova PP (2011) Toll-like and adenosine receptor expression in injured skeletal muscle. Muscle Nerve 44:85-92

107. Urso ML, Wang R, Zambraski EJ, Liang BT (2012) Adenosine $A_{3}$ receptor stimulation reduces muscle injury following physical trau$\mathrm{ma}$ and is associated with alterations in the MMP/TIMP response. J Appl Physiol 112:658-670

108. Bradbeer JN, Gowen M, Dodds RA (1992) In situ demonstration of the increased ability of human osteoclasts to generate ATP during bone resorption. J Bone Miner Res 7:S312

109. Schöfl C, Cuthbertson KS, Walsh CA, Mayne C, Cobbold P, von zur Muhlen A, Hesch RD, Gallagher JA (1992) Evidence for P2purinoceptors on human osteoblast-like cells. J Bone Miner Res 7:485-491

110. Orriss IR, Burnstock G, Arnett TR (2010) Purinergic signalling and bone remodelling. Curr Opin Pharmacol 10:322-330

111. Orriss IR, Arnett TR (2012) P2Y receptors in bone. WIREs Membr Transp Signal 1:805-814

112. Gartland A (2012) P2X receptors in bone. WIREs Membr Transp Signal 1:221-227

113. Gartland A, Orriss IR, Rumney RM, Bond AP, Arnett T, Gallagher JA (2012) Purinergic signalling in osteoblasts. Front Biosci 17: $16-29$

114. Gartland A, Buckley KA, Hipskind RA, Perry MJ, Tobias JH, Buell G, Chessell I, Bowler WB, Gallagher JA (2003) Multinucleated osteoclast formation in vivo and in vitro by $\mathrm{P}_{2} \mathrm{X}_{7}$ receptor-deficient mice. Crit Rev Eukaryot Gene Expr 13:243-253

115. Ke HZ (2005) In vivo characterization of skeletal phenotype of genetically modified mice. J Bone Miner Metab 23(Suppl):84 89

116. Steinberg TH, Hiken JF (2007) P2 receptors in macrophage fusion and osteoclast formation. Purinergic Signal 3:53-57

117. Orriss I, Evans H, Arnett T, Gartland A (2008) MicroCT analysis of $\mathrm{P} 2 \mathrm{Y} 1$ and $\mathrm{P} 2 \mathrm{Y} 2$ receptor knockout mice demonstrates significant changes in bone phenotype. Purinergic Signal 4:1-210

118. Orriss I, Syberg S, Wang N, Robaye B, Gartland A, Jorgensen N, Arnett T, Boeynaems JM (2011) Bone phenotypes of P2 receptor knockout mice. Front Biosci (Schol Ed) 3:1038-1046
119. Orriss IR, Wang N, Burnstock G, Arnett TR, Gartland A, Robaye B, Boeynaems J-M (2011) The $\mathrm{P}_{2} \mathrm{Y}_{6}$ receptor stimulates bone resorption by osteoclasts. Endocrinology 152:3706-3716

120. Su X, Floyd DH, Hughes A, Xiang J, Schneider JG, Uluckan O, Heller E, Deng H, Zou W, Craft CS, Wu K, Hirbe AC, Grabowska D, Eagleton MC, Townsley S, Collins L, Piwnica-Worms D, Steinberg TH, Novack DV, Conley PB, Hurchla MA, Rogers M, Weilbaecher KN (2012) The ADP receptor P2RY12 regulates osteoclast function and pathologic bone remodeling. $\mathrm{J}$ Clin Invest 122:3579-3592

121. Wang N, Robaye B, Agrawal A, Skerry TM, Boeynaems JM, Gartland A (2012) Reduced bone turnover in mice lacking the P2Y ${ }_{13}$ receptor of ADP. Mol Endocrinol 26:142-152

122. Syberg S, Petersen S, Beck Jensen JE, Gartland A, Teilmann J, Chessell I, Steinberg TH, Schwarz P, Jorgensen NR (2012) Genetic background strongly influences the bone phenotype of $\mathrm{P} 2 \mathrm{X} 7$ receptor knockout mice. J Osteoporos 2012:391097

123. Nijweide PJ, Modderman WE, Hagenaars CE (1995) Extracellular adenosine triphosphate. A shock to hemopoietic cells. Clin Orthop Relat Res 92-102

124. Russell RG, Rogers MJ (1999) Bisphosphonates: from the laboratory to the clinic and back again. Bone 25:97-106

125. Coxon FP, Thompson K, Rogers MJ (2006) Recent advances in understanding the mechanism of action of bisphosphonates. Curr Opin Pharmacol 6:307-312

126. Russell RG (2011) Bisphosphonates: The first 40 years. Bone 49:2-19

127. Dixon SJ, Sims SM (2000) P2 purinergic receptors on osteoblasts and osteoclasts: potential targets for drug development. Drug Dev Res 49:187-200

128. Steinberg TH, Jørgensen NR, Bong JS, Henriksen Z, Atal N, Lin GC, Bennett BD, Eriksen EF, Sørensen OH, Civitelli R (2001) P2mediated responses in osteoclasts and osteoclast-like cells. Drug Dev Res 53:126-129

129. Burnstock G, Arnett TR (2006) Edited monograph: nucleotides and regulation of bone cell function. Taylor \& Francis, Boca Raton, pp $1-207$

130. Bowler WB, Buckley KA, Gartland A, Hipskind RA, Bilbe G, Gallagher JA (2001) Extracellular nucleotide signaling: a mechanism for integrating local and systemic responses in the activation of bone remodeling. Bone 28:507-512

131. Ferrier J (2001) Purinergic and pyrimidinergic receptor signaling in bone cells. In: Abbracchio MP, Williams M (eds) Handbook of experimental pharmacology, volume 151/I. Purinergic and pyrimidinergic signalling $\mathrm{I}-$ molecular, nervous and urinogenitary system function. Springer, Berlin, pp 393-406

132. Kaunitz JD, Yamaguchi DT (2008) TNAP, TrAP, ecto-purinergic signaling, and bone remodeling. J Cell Biochem 105:655-662

133. Komarova SV, Dixon SJ, Sims SM (2001) Osteoclast ion channels: potential targets for antiresorptive drugs. Curr Pharm Des 7:637654

134. Naemsch LN, Dixon SJ, Sims SM (2001) Activity-dependent development of $\mathrm{P}_{2} \mathrm{X}_{7}$ current and $\mathrm{Ca}^{2+}$ entry in rabbit osteoclasts. J Biol Chem 276:39107-39114

135. Hoebertz A, Arnett TR, Burnstock G (2003) Regulation of bone resorption and formation by purines and pyrimidines. Trends Pharmacol Sci 24:290-297

136. Gartland A, Buckley KA, Hipskind RA, Bowler WB, Gallagher JA (2003) P2 receptors in bone-modulation of osteoclast formation and activity via $\mathrm{P}_{2} \mathrm{X}_{7}$ activation. Crit Rev Eukaryot Gene Expr 13:237242

137. Ke HZ, Qi H, Weidema AF, Zhang Q, Panupinthu N, Crawford DT, Grasser WA, Paralkar VM, Li M, Audoly LP, Gabel CA, Jee WS, Dixon SJ, Sims SM, Thompson DD (2003) Deletion of the P2X nucleotide receptor reveals its regulatory roles in bone formation and resorption. Mol Endocrinol 17:1356-1367 
138. Li J, Liu D, Ke HZ, Duncan RL, Turner CH (2005) The $\mathrm{P}_{2} \mathrm{X}_{7}$ nucleotide receptor mediates skeletal mechanotransduction. J Biol Chem 280:42952-42959

139. Grol MW, Panupinthu N, Korcok J, Sims SM, Dixon SJ (2009) Expression, signaling, and function of $\mathrm{P} 2 \mathrm{X} 7$ receptors in bone. Purinergic Signal 5:205-221

140. Spencer GJ, Hitchcock IS, Genever PG (2004) Emerging neuroskeletal signalling pathways: a review. FEBS Lett 559:6-12

141. Turner CH, Robling AG (2004) Exercise as an anabolic stimulus for bone. Curr Pharm Des 10:2629-2641

142. Jørgensen NR (2005) Short-range intercellular calcium signaling in bone. APMIS Suppl 5-36

143. Chan ES, Fernandez P, Cronstein BN (2007) Adenosine in inflammatory joint diseases. Purinergic Signal 3:145-152

144. Supanchart C, Kornak U (2008) Ion channels and transporters in osteoclasts. Arch Biochem Biophys 473:161-165

145. Intini G (2009) The use of platelet-rich plasma in bone reconstruction therapy. Biomaterials 30:4956-4966

146. Sekrecka-Belniak A, Balcerzak M, Buchet R, Pikula S (2010) Active creatine kinase is present in matrix vesicles isolated from femurs of chicken embryo: implications for bone mineralization. Biochem Biophys Res Commun 391:1432-1436

147. Arnett TR (2010) Acidosis, hypoxia and bone. Arch Biochem Biophys 503:103-109

148. Varani K, Padovan M, Govoni M, Vincenzi F, Trotta F, Borea PA (2010) The role of adenosine receptors in rheumatoid arthritis. Autoimmun Rev 10:61-64

149. Lerner UH, Sahlberg K, Fredholm BB (1987) Characterization of adenosine receptors in bone. Studies on the effect of adenosine analogues on cyclic AMP formation and bone resorption in cultured mouse calvaria. Acta Physiol Scand 131:287-296

150. Shimegi S (1998) Mitogenic action of adenosine on osteoblast-like cells, MC3T3-E1. Calcif Tissue Int 62:418-425

151. Yu H, Ferrier J (1993) Osteoblast-like cells have a variable mixed population of purino/nucleotide receptors. FEBS Lett 328:209-214

152. Sistare FD, Rosenzweig BA, Contrera JG, Jordan B (1994) Separate $\mathrm{P}_{2 \mathrm{~T}}$ and $\mathrm{P}_{2 \mathrm{U}}$ purinergic receptors with similar second messenger signalling pathways in UMR-106 osteoblasts. J Pharmacol Exp Ther 269:1049-1061

153. Gallinaro BJ, Reimer WJ, Dixon SJ (1995) Activation of protein kinase $\mathrm{C}$ inhibits ATP-induced $\left[\mathrm{Ca}^{2+}\right]_{\mathrm{i}}$ elevation in rat osteoblastic cells: selective effects on $\mathrm{P}_{2 \mathrm{Y}}$ and $\mathrm{P}_{2 \mathrm{U}}$ signaling pathways. J Cell Physiol 162:305-314

154. Shimegi S (1996) ATP and adenosine act a mitogen for osteoblastlike cells (MC3T3-E1). Calcif Tissue Int 58:109-113

155. Suzuki A, Kotoyori J, Oiso Y, Kozawa O (1993) Prostaglandin $E_{2}$ is a potential mediator of extracellular ATP action in osteoblast-like cells. Cell Adhes Commun 1:113-118

156. Bowler WB, Birch MA, Gallagher JA, Bilbe G (1995) Identification and cloning of human $\mathrm{P}_{2 \mathrm{U}}$ purinoceptor present in osteoclastoma, bone, and osteoblasts. J Bone Miner Res 10:1137-1145

157. Dixon CJ, Bowler WB, Walsh CA, Gallagher JA (1997) Effects of extracellular nucleotides on single cells and populations of human osteoblasts: contribution of cell heterogeneity to relative potencies. Br J Pharmacol 120:777-780

158. Orriss I, Knight GE, Ramasingh S, Burnstock G, Arnett TR (2006) Osteoblast responses to nucleotides increase during differentiation. Bone 39:300-309

159. Strohbach CA, Genetos DC, Taylor AF, Donahue HJ (2004) Differentiation affects MC3T3-E1 mechanoresponsiveness and P2Y2 expression. J Bone Miner Res 19:S257

160. Nishii N, Nejime N, Yamauchi C, Yanai N, Shinozuka K, Nakabayashi T (2009) Effects of ATP on the intracellular calcium level in the osteoblastic TBR31-2 cell line. Biol Pharm Bull 32:18-23

161. Maier R, Glatz A, Mosbacher J, Bilbe G (1997) Cloning of P2Y6 cDNAs and identification of a pseudogene: comparison of $\mathrm{P} 2 \mathrm{Y}$ receptor subtype expression in bone and brain tissues. Biochem Biophys Res Commun 240:298-302

162. Ihara H, Hirukawa K, Goto S, Togari A (2005) ATP-stimulated interleukin-6 synthesis through P2Y receptors on human osteoblasts. Biochem Biophys Res Commun 326:329-334

163. Buckley KA, Wagstaff SC, McKay G, Gaw A, Hipskind RA, Bilbe G, Gallagher JA, Bowler WB (2001) Parathyroid hormone potentiates nucleotide-induced $\left[\mathrm{Ca}^{2+}\right]_{\mathrm{i}}$ release in rat osteoblasts independently of $\mathrm{G}_{\mathrm{q}}$ activation or cyclic monophosphate accumulation. A mechanism for localizing systemic responses in bone. J Biol Chem 276:9565-9571

164. Jørgensen NR, Geist ST, Civitelli R, Steinberg TH (1997) ATP- and gap junction-dependent intercellular calcium signaling in osteoblastic cells. J Cell Biol 139:497-506

165. Li DL, Liu X, Xia R, Ross C, Yang X, Jiang LH (2009) Pharmacological properties of ATP-sensitive purinergic receptors expressed in human G292 osteoblastic cells. Eur J Pharmacol 617:12-16

166. Hoebertz A, Townsend-Nicholson A, Glass R, Burnstock G, Arnett TR (2000) Expression of $\mathrm{P} 2$ receptors in bone and cultured bone cells. Bone 27:503-510

167. Orriss IR, Key ML, Brandao-Burch A, Burnstock G, Arnett TR (2012) The regulation of osteoblast function and bone mineralisation by extracellular nucleotides: the role of P2X receptors. Bone 51:389-400

168. Syberg S, Brandao-Burch A, Patel JJ, Hajjawi M, Arnett TR, Schwarz P, Jorgensen NR, Orriss IR (2012) Clopidogrel (Plavix ${ }^{\circledR}$ ), a P2Y 12 receptor antagonist, inhibits bone cell function in vitro and decreases trabecular bone in vivo. J Bone Miner Res 27:2373-2386

169. Gartland A, Hipskind RA, Gallagher JA, Bowler WB (2001) Expression of a $\mathrm{P} 2 \mathrm{X}_{7}$ receptor by a subpopulation of human osteoblasts. J Bone Miner Res 16:846-856

170. Gangadharan V, Nohe A, Duncan R (2011) ATP stimulates calveolar endocytosis of $\mathrm{P} 2 \mathrm{X}_{7} \mathrm{R}$ in $\mathrm{MC} 3 \mathrm{~T} 3-\mathrm{E} 1$ osteoblasts. Biophys J 100:418

171. Nakamura E, Uezono Y, Narusawa K, Shibuya I, Oishi Y, Tanaka M, Yanagihara N, Nakamura T, Izumi F (2000) ATP activates DNA synthesis by acting on $\mathrm{P} 2 \mathrm{X}$ receptors in human osteoblast-like MG63 cells. Am J Physiol Cell Physiol 279:C510-C519

172. Alqallaf SM, Evans BA, Kidd EJ (2009) Atypical P2X receptor pharmacology in two human osteoblast-like cell lines. Br J Pharmacol 156:1124-1135

173. Suzuki A, Shinoda J, Oiso Y, Kozawa O (1995) Mechanism of phospholipase D activation induced by extracellular ATP in osteoblast-like cells. J Endocrinol 145:81-86

174. Katz S, Boland R, Santillán G (2006) Modulation of ERK 1/2 and p38 MAPK signaling pathways by ATP in osteoblasts: involvement of mechanical stress-activated calcium influx, PKC and Src activation. Int J Biochem Cell Biol 38:2082-2091

175. Katz S, Boland R, Santillén G (2008) Purinergic (ATP) signaling stimulates JNK1 but not JNK2 MAPK in osteoblast-like cells: contribution of intracellular $\mathrm{Ca}^{2+}$ release, stress activated and Lvoltage-dependent calcium influx, PKC and Src kinases. Arch Biochem Biophys 477:244-252

176. Katz S, Ayala V, Santillán G, Boland R (2011) Activation of the $\mathrm{PI} 3 \mathrm{~K} /$ Akt signaling pathway through $\mathrm{P}_{2} \mathrm{Y}_{2}$ receptors by extracellular ATP is involved in osteoblastic cell proliferation. Arch Biochem Biophys 513:144-152

177. Ayala-Peña VB, Scolaro LA, Santillán GE (2013) ATP and UTP stimulate bone morphogenetic protein-2, -4 and -5 gene expression and mineralization by rat primary osteoblasts involving $\mathrm{PI} 3 \mathrm{~K} / \mathrm{AKT}$ pathway. Exp Cell Res 319:2028-2036

178. Gu Y, Xing YH, Donahue HJ, You J (2006) G-Protein coupled receptor kinase 2 inhibits ATP induced activation of ERKl/2 signaling pathway in osteoblasts. J Bone Miner Res 21:S258

179. Pines A, Romanello M, Cesaratto L, Damante G, Moro L, D'Andrea P, Tell G (2003) Extracellular ATP stimulates the early growth response 
protein 1 (Egr-1) via a protein kinase C-dependent pathway in the human osteoblastic HOBIT cell line. Biochem J 373:815-824

180. Costessi A, Pines A, D'Andrea P, Romanello M, Damante G, Cesaratto L, Quadrifoglio F, Moro L, Tell G (2005) Extracellular nucleotides activate Runx2 in the osteoblast-like HOBIT cell line: a possible molecular link between mechanical stress and osteoblasts' response. Bone 36:418-432

181. Qi J, Chi L, Faber J, Koller B, Banes AJ (2007) ATP reduces gel compaction in osteoblast-populated collagen gels. J Appl Physiol 102:1152-1160

182. Qi J, Chi L, Wang J, Sumanasinghe R, Wall M, Tsuzaki M, Banes AJ (2009) Modulation of collagen gel compaction by extracellular ATP is MAPK and NF-kB pathways dependent. Exp Cell Res 315:1990-2000

183. Hirukawa K, Muraki K, Ohya S, Imaizumi Y, Togari A (2008) Electrophysiological properties of a novel $\mathrm{Ca}^{2+}$-activated $\mathrm{K}^{+}$channel expressed in human osteoblasts. Calcif Tissue Int 83:222-229

184. Silber AS, Pfau B, Tan TW, Jacob R, Jones D, Meyer T (2012) Dynamic redistribution of paxillin in bovine osteoblasts stimulated with adenosine 5'-triphosphate. J Mol Histol 43:571580

185. Kaplan AD, Reimer WJ, Feldman RD, Dixon SJ (1995) Extracellular nucleotides potentiate the cytosolic $\mathrm{Ca}^{2+}$, but not cyclic adenosine 3',5'-monophosphate response to parathyroid hormone in rat osteoblastic cells. Endocrinology 136:1674-1685

186. Sistare FD, Rosenzweig BA, Contrera JG (1995) $\mathrm{P}_{2}$ purinergic receptors potentiate parathyroid hormone receptor-mediated increases in intracellular calcium and inositol triphosphate in UMR106 rat osteoblasts. Endocrinology 136:4489-4497

187. Bowler WB, Dixon CJ, Halleux C, Maier R, Bilbe G, Fraser WD, Gallagher JA, Hipskind RA (1999) Signaling in human osteoblasts by extracellular nucleotides. Their weak induction of the $c$-fos proto-oncogene via $\mathrm{Ca}^{2+}$ mobilization is strongly potentiated by a parathyroid hormone/cAMP-dependent protein kinase pathway independently of mitogen-activated protein kinase. J Biol Chem 274:14315-14324

188. Nakao Y, Koike T, Ohta Y, Manaka T, Imai Y, Takaoka K (2009) Parathyroid hormone enhances bone morphogenetic protein activity by increasing intracellular 3',5'-cyclic adenosine monophosphate accumulation in osteoblastic MC3T3-E1 cells. Bone 44:872-877

189. Roy AA, Nunn C, Ming H, Zou MX, Penninger J, Kirshenbaum LA, Dixon SJ, Chidiac P (2006) Up-regulation of endogenous RGS2 mediates cross-desensitization between $\mathrm{G}_{\mathrm{s}}$ and $\mathrm{G}_{\mathrm{q}}$ signaling in osteoblasts. J Biol Chem 281:32684-32693

190. Watanabe-Tomita Y, Suzuki A, Shinoda J, Oiso Y, Kozawa O (1997) Arachidonic acid release induced by extracellular ATP in osteoblasts: role of phospholipase D. Prostaglandins Leukot Essent Fatty Acids 57:335-339

191. Pacheco-Pantoja EL, Dillon JP, Wilson PJM, Ranganath L, Fraser WD, Gallagher JA (2009) Extracellular ATP, signalling through P2 receptors, synergises with glucose-dependent insulinotropic polypeptide to induce c-fos in osteoblastic cells. Bone 44:S356

192. You J, Jacobs CR, Steinberg TH, Donahue HJ (2002) P2Y purinoceptors are responsible for oscillatory fluid flow-induced intracellular calcium mobilization in osteoblastic cells. J Biol Chem 277:48724-48729

193. Genetos DC, Kephart CJ, Zhang Y, Yellowley CE, Donahue HJ (2007) Oscillating fluid flow activation of gap junction hemichannels induces ATP release from MLO-Y4 osteocytes. J Cell Physiol 212:207-214

194. Henriksen Z, Hiken JF, Steinberg TH, Jørgensen NR (2006) The predominant mechanism of intercellular calcium wave propagation changes during long-term culture of human osteoblast-like cells. Cell Calcium 39:435-444

195. Huo B, Lu XL, Costa KD, Xu Q, Guo XE (2010) An ATPdependent mechanism mediates intercellular calcium signaling in bone cell network under single cell nanoindentation. Cell Calcium 47:234-241

196. Huo B, Lu XL, Guo XE (2010) Intercellular calcium wave propagation in linear and circuit-like bone cell networks. Philos Transact A Math Phys Eng Sci 368:617-633

197. Gardinier JD, Majumdar S, Duncan RL, Wang L (2009) Cyclic hydraulic pressure and fluid flow differentially modulate cytoskeleton re-organization in MC3T3 osteoblasts. Cell Mol Bioeng 2:133-143

198. Nam SH, Jung SY, Yoo CM, Ahn EH, Suh CK (2002) $\mathrm{H}_{2} \mathrm{O}_{2}$ enhances $\mathrm{Ca}^{2+}$ release from osteoblast internal stores. Yonsei Med J 43:229-235

199. D'Andrea P, Romanello M, Bicego M, Steinberg TH, Tell G (2006) $\mathrm{H}_{2} \mathrm{O}_{2}$ activates purinergic signalling in osteoblasts. Purinergic Signal 2:221

200. D'Andrea P, Romanello M, Bicego M, Steinberg TH, Tell G (2008) $\mathrm{H}_{2} \mathrm{O}_{2}$ modulates purinergic-dependent calcium signalling in osteoblast-like cells. Cell Calcium 43:457-468

201. Nakano Y, Addison WN, Kaartinen MT (2007) ATP-mediated mineralization of MC3T3-E1 osteoblast cultures. Bone 41:549-561

202. Jones SJ, Gray C, Boyde A, Burnstock G (1997) Purinergic transmitters inhibit bone formation by cultured osteoblasts. Bone 21:393-399

203. Orriss IR, Utting JC, Brandao-Burch A, Colston K, Grubb BR, Burnstock G, Arnett TR (2007) Extracellular nucleotides block bone mineralisation in vitro: evidence for dual inhibitory mechanisms involving both $\mathrm{P}_{2} \mathrm{Y}_{2}$ receptors and pyrophosphate. Endocrinology 148:4208-4216

204. Orriss IR, Arnett TR (2010) Extracellular nucleotides regulate the expression and activity of ecto-nucleotidases by osteoblasts. Bone 46:S55

205. Orriss IR, Key ML, Hajjawi MOR, Arnett TR (2013) Extracellular ATP released by osteoblasts is a key local inhibitor of mineralisation. PLoS One, 8:e69057

206. Jørgensen NR, Grove EL, Schwarz P, Vestergaard P (2012) Clopidogrel and the risk of osteoporotic fractures: a nationwide cohort study. J Intern Med 272:385-393

207. Biver G, Wang N, Gartland A, Orriss I, Arnett TR, Boeynaems JM, Robaye B (2013) Role of the P2Y13 receptor in the differentiation of bone marrow stromal cells into osteoblasts and adipocytes. Stem Cells. doi:10.1002/stem.1411

208. Henriksen BM, Nissen N, Jørgensen NR (2006) Functional P2X7 purinergic receptors are expressed in differentiated human osteoblasts. J Bone Miner Res 21:S258

209. Panupinthu N, Rogers JT, Zhao L, Solano-Flores LP, Possmayer F, Sims SM, Dixon SJ (2008) P2X7 receptors on osteoblasts couple to production of lysophosphatidic acid: a signaling axis promoting osteogenesis. J Cell Biol 181:859-871

210. Panupinthu N, Zhao L, Possmayer F, Ke HZ, Sims SM, Dixon SJ (2007) P2X7 nucleotide receptors mediate blebbing in osteoblasts through a pathway involving lysophosphatidic acid. J Biol Chem 282:3403-3412

211. Brandao-Burch A, Key ML, Patel JJ, Arnett TR, Orriss IR (2012) The P2X7 receptor is an important regulator of extracellular ATP levels. Front Endocrinol (Lausanne) 3:41

212. Rumney RM, Wang N, Gartland A (2010) The role of P2X 7 receptors in ATP release from osteoblasts. Purinergic Signal 6:129

213. Genetos DC, Karin NJ, Geist DJ, Donahue HJ, Duncan RL (2011) Purinergic signaling is required for fluid shear stress-induced NFKB translocation in osteoblasts. Exp Cell Res 317:737-744

214. Grol MW, Zelner I, Dixon SJ (2012) P2X $X_{7}$-mediated calcium influx triggers a sustained, PI3K-dependent increase in metabolic acid production by osteoblast-like cells. Am J Physiol Endocrinol Metab 302:E561-E575

215. Petersen S, Syberg S, Henriksen Z, Schwarz P, Jensen JE, Sørensen $\mathrm{OH}$, Jørgensen NR (2007) The purinergic P2X7 receptor is 
responsible for ovariectomy-induced bone loss in mice. J Bone Miner Res 21:S258

216. Li J, Meyer R, Duncan RL, Turner CH (2009) P2X7 nucleotide receptor plays an important role in callus remodeling during fracture repair. Calcif Tissue Int 84:405-412

217. Genetos DC, Geist DJ, Liu D, Donahue HJ, Duncan RL (2005) Fluid shear-induced ATP secretion mediates prostaglandin release in MC3T3-E1 osteoblasts. J Bone Miner Res 20:41-49

218. Liu D, Genetos DC, Shao Y, Geist DJ, Li J, Ke HZ, Turner CH, Duncan RL (2008) Activation of extracellular-signal regulated kinase $(\mathrm{ERK} 1 / 2)$ by fluid shear is $\mathrm{Ca}^{2+}$ - and ATP-dependent in MC3T3-E1 osteoblasts. Bone 42:644-652

219. Okumura H, Shiba D, Kubo T, Yokoyama T (2008) P2X7 receptor as sensitive flow sensor for ERK activation in osteoblasts. Biochem Biophys Res Commun 372:486-490

220. Nicke A, Kuan YH, Masin M, Rettinger J, Marquez-Klaka B, Bender O, Gorecki DC, Murrell-Lagnado RD, Soto F (2009) A functional $\mathrm{P} 2 \mathrm{X} 7$ splice variant with an alternative transmembrane domain 1 escapes gene inactivation in P2X7 knock-out mice. J Biol Chem 284:25813-25822

221. Husted LB, Gonzalez-Bofill N, Carstens M, Stenkjaer L, Langdahl BL (2007) Gain-of-function polymorphisms in the $\mathrm{P} 2 \mathrm{X} 7$ purinergic receptor are associated with increased bone mass. Calcif Tissue Int 80:S99-S100

222. Ohlendorff SD, Tofteng CL, Jensen JE, Petersen S, Civitelli R, Fenger M, Abrahamsen B, Hermann AP, Eiken P, Jorgensen NR (2007) Single nucleotide polymorphisms in the $\mathrm{P} 2 \mathrm{X}_{7}$ gene are associated to fracture risk and to effect of estrogen treatment. Pharmacogenet Genomics 17:555-567

223. Husted LB, Harsløf T, Stenkjær L, Carstens M, Jørgensen NR, Langdahl BL (2013) Functional polymorphisms in the $\mathrm{P} 2 \mathrm{X}_{7}$ receptor gene are associated with osteoporosis. Osteoporos Int 24:949959

224. Gartland A, Skarratt KK, Hocking LJ, Parsons C, Stokes L, Jorgensen NR, Fraser WD, Reid DM, Gallagher JA, Wiley JS (2012) Polymorphisms in the P2X7 receptor gene are associated with low lumbar spine bone mineral density and accelerated bone loss in post-menopausal women. Eur J Hum Genet 20:559-564

225. Romanello M, Pani B, Bicego M, D'Andrea P (2001) Mechanically induced ATP release from human osteoblastic cells. Biochem Biophys Res Commun 289:1275-1281

226. Romanello M, Codognotto A, Bicego M, Pines A, Tell G, D'Andrea $P$ (2005) Autocrine/paracrine stimulation of purinergic receptors in osteoblasts: contribution of vesicular ATP release. Biochem Biophys Res Commun 331:1429-1438

227. Gartland A, Burrell HE, Dillon JP, Mwaura BK, Hayton MJ, Gallagher JA (2006) Release of ATP from human osteoblasts occurs via a calcium dependent, exocytotic vesicular mechanism. Purinergic Signal 2:4

228. Orriss IR, Knight GE, Utting JC, Taylor SEB, Burnstock G, Arnett TR (2009) Hypoxia stimulates vesicular ATP release from rat osteoblasts. J Cell Physiol 220:155-162

229. Sabirov RZ, Okada Y (2009) The maxi-anion channel: a classical channel playing novel roles through an unidentified molecular entity. J Physiol Sci 59:3-21

230. Thi MM, Islam S, Suadicani SO, Spray DC (2012) Connexin43 and pannexin1 channels in osteoblasts: who is the "hemichannel"? J Membr Biol 245:401-409

231. Shao Y, Fomin VP, Farach-Carson MC, Duncan RL (2008) Ahnak regulates calcium signaling and ATP release in osteoblasts in response to mechanical stimulation. J Bone Miner Res 23:S139

232. Asada K, Obata K, Horiguchi K, Takaki M (2012) Age-related changes in afferent responses in sensory neurons to mechanical stimulation of osteoblasts in coculture system. Am J Physiol Cell Physiol 302:C757-C765
233. Hecht E, Liedert A, Ignatius A, Mizaikoff B, Kranz C (2013) Local detection of mechanically induced ATP release from bone cells with ATP microbiosensors. Biosens Bioelectron 44:27-33

234. Rumney RM, Sunters A, Reilly GC, Gartland A (2012) Application of multiple forms of mechanical loading to human osteoblasts reveals increased ATP release in response to fluid flow in 3D cultures and differential regulation of immediate early genes. $\mathrm{J}$ Biomech 45:549-554

235. Biswas P, Zanello LP (2009) $1 \alpha, 25(\mathrm{OH})_{2}$ vitamin $\mathrm{D}_{3}$ induction of ATP secretion in osteoblasts. J Bone Miner Res 24:1450-1460

236. Biswas $P$, Zanello LP (2006) Vitamin $\mathrm{D}_{3}$ rapidly regulates ATP release via $\mathrm{L}-\mathrm{Ca}$ and $\mathrm{CIC}-3$ channels in osteoblasts. Biophys $\mathrm{J}$ $172 \mathrm{~A}$

237. Hayton MJ, Dillon JP, Glynn D, Curran JM, Gallagher JA, Buckley KA (2005) Involvement of adenosine 5'-triphosphate in ultrasoundinduced fracture repair. Ultrasound Med Biol 31:1131-1138

238. Alvarenga ÉC, Rodrigues R, Caricati-Neto A, Silva-Filho FC, Paredes-Gamero EJ, Ferreira AT (2010) Low-intensity pulsed ultrasound-dependent osteoblast proliferation occurs by via activation of the $\mathrm{P} 2 \mathrm{Y}$ receptor: role of the $\mathrm{P} 2 \mathrm{Y}_{1}$ receptor. Bone $46: 355-362$

239. Romanello M, Bivi N, Pines A, Deganuto M, Quadrifoglio F, Moro L, Tell G (2006) Bisphosphonates activate nucleotide receptors signaling and induce the expression of Hsp90 in osteoblast-like cell lines. Bone 39:739-753

240. Zimmermann H, Zebisch M, Strater N (2012) Cellular function and molecular structure of ecto-nucleotidases. Purinergic Signal 8:437502

241. Buckley KA, Golding SL, Rice JM, Dillon JP, Gallagher JA (2003) Release and interconversion of $\mathrm{P} 2$ receptor agonists by human osteoblast-like cells. FASEB J 17:1401-1410

242. Mackenzie NC, Zhu D, Milne EM, vańt Hof R, Martin A, Darryl QL, Millán JL, Farquharson C, Macrae VE (2012) Altered bone development and an increase in FGF-23 expression in Enpp $1^{-/}$ mice. PLoS One 7:e32177

243. Ham J, Evans BA (2012) An emerging role for adenosine and its receptors in bone homeostasis. Front Endocrinol (Lausanne) 3:113

244. Evans BA, Elford C, Pexa A, Francis K, Hughes AC, Deussen A, Ham J (2006) Human osteoblast precursors produce extracellular adenosine, which modulates their secretion of IL-6 and osteoprotegerin. J Bone Miner Res 21:228-236

245. Costa MA, Barbosa A, Neto E, Sá-e-Sousa A, Freitas R, Neves JM, Magalhães-Cardoso T, Ferreirinha F, Correia-de-Sá P (2011) On the role of subtype selective adenosine receptor agonists during proliferation and osteogenic differentiation of human primary bone marrow stromal cells. J Cell Physiol 226:1353-1366

246. Takedachi M, Oohara H, Smith BJ, Iyama M, Kobashi M, Maeda K, Long CL, Humphrey MB, Stoecker BJ, Toyosawa S, Thompson LF, Murakami S (2012) CD73-generated adenosine promotes osteoblast differentiation. J Cell Physiol 227:2622-2631

247. Carroll SH, Wigner NA, Kulkarni N, Johnston-Cox H, Gerstenfeld LC, Ravid K (2012) A2B adenosine receptor promotes mesenchymal stem cell differentiation to osteoblasts and bone formation in vivo. J Biol Chem 287:15718-15727

248. Fatokun AA, Stone TW, Smith RA (2006) Hydrogen peroxideinduced oxidative stress in MC3T3-E1 cells: The effects of glutamate and protection by purines. Bone 39:542-551

249. Huo B, Lu XL, Hung CT, Costa KD, Xu Q, Whitesides GM, Guo $\mathrm{XE}$ (2008) Fluid flow induced calcium response in bone cell network. Cell Mol Bioeng 1:58-66

250. Thompson WR, Majid AS, Czymmek KJ, Ruff AL, García J, Duncan RL, Farach-Carson MC (2011) Association of the $\alpha_{2} \delta_{1}$ subunit with $\mathrm{Ca}_{\mathrm{v}} 3.2$ enhances membrane expression and regulates mechanically induced ATP release in MLO-Y4 osteocytes. J Bone Miner Res 26:2125-2139 
251. Kringelbach TM, Schwarz P, Novak I, Bonewald LF, Vang O, Jørgensen NR (2008) P2 receptors are functionally expressed in MLO-Y4 osteocytes. Purinergic Signal 4:S173-S174

252. Kringelbach TM, Novak I, Bonewald LF, Vang O, Schwarz P, Jørgensen NR (2012) UTP and mechanical stimulation induce ATP release from osteocytes. Bone 50:S95

253. Yu H, Ferrier J (1995) Osteoclast ATP receptor activation leads to a transient decrease in intracellular $\mathrm{pH}$. J Cell Sci 108:3051-3058

254. Weidema AF, Barbera J, Dixon SJ, Sims SM (1997) Extracellular nucleotides activate non-selective cation and $\mathrm{Ca}^{2+}$-dependent $\mathrm{K}^{+}$ channels in rat osteoclasts. J Physiol 503:303-315

255. Wiebe SH, Sims SM, Dixon SJ (1999) Calcium signalling via multiple P2 purinoceptor subtypes in rat osteoclasts. Cell Physiol Biochem 9:323-337

256. Naemsch LN, Weidema AF, Sims SM, Underhill TM, Dixon SJ

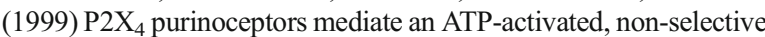
cation current in rabbit osteoclasts. J Cell Sci 112:4425-4435

257. Weidema AF, Dixon SJ, Sims SM (2001) Activation of P2Y but not $\mathrm{P} 2 \mathrm{X}_{4}$ nucleotide receptors causes elevation of $\left[\mathrm{Ca}^{2+}\right]_{\mathrm{i}}$ in mammalian osteoclasts. Am J Physiol Cell Physiol 280:C1531-C1539

258. Buckley KA, Hipskind RA, Gartland A, Bowler WB, Gallagher JA (2002) Adenosine triphosphate stimulates human osteoclast activity via upregulation of osteoblast-expressed receptor activator of nuclear factor- $\mathrm{KB}$ ligand. Bone 31:582-590

259. Bowler WB, Littlewood-Evans A, Bilbe G, Gallagher JA, Dixon CJ (1998) P2Y2 receptors are expressed by human osteoclasts of giant cell tumor but do not mediate ATP-induced bone resorption. Bone 22:195-200

260. Wildman SS, King BF, Burnstock G (1998) $\mathrm{Zn}^{2+}$ modulation of ATP-responses at recombinant $\mathrm{P} 2 \mathrm{X}_{2}$ receptors and its dependence on extracellular $\mathrm{pH}$. Br J Pharmacol 123:1214-1220

261. Hoebertz A, Meghji S, Burnstock G, Arnett TR (2001) Extracellular ADP is a powerful osteolytic agent: evidence for signaling through the $\mathrm{P}_{2} \mathrm{Y}_{1}$ receptor on bone cells. FASEB J 15:1139-1148

262. Hollopeter G, Jantzen H-M, Vincent D, Li G, England L, Ramakrishnan V, Yang R-B, Nurden P, Nurden A, Julius D, Conley PB (2001) Identification of the platelet ADP receptor targeted by antithrombotic drugs. Nature 409:202-207

263. Korcok J, Raimundo LN, Ke HZ, Sims SM, Dixon SJ (2004) Extracellular nucleotides act through $\mathrm{P} 2 \mathrm{X} 7$ receptors to activate NF- $\mathrm{kB}$ in osteoclasts. J Bone Miner Res 19:642-651

264. Weidema AF, Dixon SJ, Sims SM (2000) Electrophysiological characterization of ion channels in osteoclasts isolated from human deciduous teeth. Bone 27:5-11

265. Korcok J, Raimundo LN, Du X, Sims SM, Dixon SJ (2005) P2Y6 nucleotide receptors activate NF- $\mathrm{kB}$ and increase survival of osteoclasts. J Biol Chem 280:16909-16915

266. Naemsch LN, Du X, Sims SM, Dixon SJ (2001) P2 nucleotide receptors in osteoclasts. Drug Dev Res 130-139

267. Gartland A, Buckley KA, Bowler WB, Gallagher JA (2003) Blockade of the pore-forming $\mathrm{P} 2 \mathrm{X}_{7}$ receptor inhibits formation of multinucleated human osteoclasts in vitro. Calcif Tissue Int 73:361-369

268. Penolazzi L, Bianchini E, Lambertini E, Baraldi PG, Romagnoli R, Piva R, Gambari R (2005) $N$-Arylpiperazine modified analogues of the $\mathrm{P} 2 \mathrm{X} 7$ receptor $\mathrm{KN}-62$ antagonist are potent inducers of apoptosis of human primary osteoclasts. J Biomed Sci 12:1013-1020

269. Hiken JF, Steinberg TH (2004) ATP downregulates $\mathrm{P}_{2} \mathrm{X}_{7}$ and inhibits osteoclast formation in RAW cells. Am J Physiol Cell Physiol 287:C403-C412

270. Armstrong S, Pereverzev A, Dixon SJ, Sims SM (2009) Activation of $\mathrm{P} 2 \mathrm{X} 7$ receptors causes isoform-specific translocation of protein kinase C in osteoclasts. J Cell Sci 122:136-144

271. Jorgensen NR, Henriksen Z, Sorensen OH, Eriksen EF, Civitelli R, Steinberg TH (2002) Intercellular calcium signaling occurs between human osteoblasts and osteoclasts and requires activation of osteoclast P2X7 receptors. J Biol Chem 277:7574-7580
272. Hazama R, Qu X, Yokoyama K, Tanaka C, Kinoshita E, He J, Takahashi S, Tohyama K, Yamamura H, Tohyama Y (2009) ATPinduced osteoclast function: the formation of sealing-zone like structure and the secretion of lytic granules via microtubuledeacetylation under the control of Syk. Genes Cells 14:871-884

273. Pellegatti P, Falzoni S, Donvito G, Lemaire I, Di Virgilio F (2011) $\mathrm{P} 2 \mathrm{X} 7$ receptor drives osteoclast fusion by increasing the extracellular adenosine concentration. FASEB J 25:1264-1274

274. Morimoto R, Uehara S, Yatsushiro S, Juge N, Hua Z, Senoh S, Echigo N, Hayashi M, Mizoguchi T, Ninomiya T, Udagawa N, Omote H, Yamamoto A, Edwards RH, Moriyama Y (2006) Secretion of L-glutamate from osteoclasts through transcytosis. EMBO J 25:4175-4186

275. Bond A, Wilson PJM, Dillon JP, Pacheco-Pantoja EL, Fraser WD, Jarvis JC, Gallagher JA (2010) ATP is released from osteoclasts and osteoblasts and sensitises bone to the action of PTH and other systemic hormones. Purinergic Signal 6:143-144

276. Cherruau M, Facchinetti P, Baroukh B, Saffar JL (1999) Chemical sympathectomy impairs bone resorption in rats: a role for the sympathetic system on bone metabolism. Bone 25:545-551

277. Binderman I, Bahar H, Jacob-Hirsch J, Zeligson S, Amariglio N, Rechavi G, Shoham S, Yaffe A (2007) P2X4 is up-regulated in gingival fibroblasts after periodontal surgery. J Dent Res 86:181-185

278. Miyazaki T, Iwasawa M, Nakashima T, Mori S, Shigemoto K, Nakamura H, Katagiri H, Takayanagi H, Tanaka S (2012) Intracellular and extracellular ATP coordinately regulate the inverse correlation between osteoclast survival and bone resorption. J Biol Chem 287:37808-37823

279. Räikkönen J, Crockett JC, Rogers MJ, Mönkkönen H, Auriola S, Mönkkönen J (2009) Zoledronic acid induces formation of a proapoptotic ATP analogue and isopentenyl pyrophosphate in osteoclasts in vivo and in MCF-7 cells in vitro. Br J Pharmacol 157:427435

280. Lerner U, Fredholm BB (1983) Studies on the mechanisms by which 2-chloroadenosine stimulates bone resorption in tissue culture. Biochim Biophys Acta 757:226-234

281. Lerner U, Fredholm BB (1985) Prostaglandin $E_{2}$ and 2chloroadenosine act in concert to stimulate bone resorption in cultured murine calvarial bones. Biochem Pharmacol 34:937-940

282. Kara FM, Chitu V, Sloane J, Axelrod M, Fredholm BB, Stanley ER, Cronstein BN (2010) Adenosine A1 receptors (A1Rs) play a critical role in osteoclast formation and function. FASEB J 24:2325-2333

283. He W, Cronstein BN (2012) Adenosine A1 receptor regulates osteoclast formation by altering TRAF6/TAK1 signaling. Purinergic Signal 8:327-337

284. Kara FM, Doty SB, Boskey A, Goldring S, Zaidi M, Fredholm BB, Cronstein $B N(2010)$ Adenosine $A_{1}$ receptors regulate bone resorption in mice: adenosine $A_{1}$ receptor blockade or deletion increases bone density and prevents ovariectomy-induced bone loss in adenosine $\mathrm{A}_{1}$ receptor-knockout mice. Arthritis Rheum 62:534-541

285. Mediero A, Kara FM, Wilder T, Cronstein BN (2012) Adenosine $\mathrm{A}_{2 \mathrm{~A}}$ receptor ligation inhibits osteoclast formation. Am J Pathol 180:775-786

286. Mediero A, Frenkel SR, Wilder T, He W, Mazumder A, Cronstein $\mathrm{BN}$ (2012) Adenosine $\mathrm{A}_{2 \mathrm{~A}}$ receptor activation prevents wear particle-induced osteolysis. Sci Transl Med 135ra65:4

287. Teramachi J, Kukita A, Qu P, Wada N, Li YJ, Nakamura S, Kukita T (2013) Adenosine blocks aminopterin-induced suppression of osteoclast differentiation. J Bone Miner Metab 31:64-70

288. Mansour A, Abou-Ezzi G, Sitnicka E, Jacobsen SE, Wakkach A, Blin-Wakkach C (2012) Osteoclasts promote the formation of hematopoietic stem cell niches in the bone marrow. J Exp Med 209:537-549

289. Riddle RC, Taylor AF, Rogers JR, Donahue HJ (2007) ATP release mediates fluid flow-induced proliferation of human bone marrow stromal cells. J Bone Miner Res 22:589-600 
290. Rossi L, Manfredini R, Bertolini F, Ferrari D, Fogli M, Zini R, Salati S, Salvestrini V, Gulinelli S, Adinolfi E, Ferrari S, Di Virgilio F, Baccarani M, Lemoli RM (2007) The extracellular nucleotide UTP is a potent inducer of hematopoietic stem cell migration. Blood 109:533-542

291. Noronha-Matos JB, Costa MA, Magalhães-Cardoso MT, Ferreirinha F, Pelletier J, Freitas R, Neves JM, Sévigny J, Correia-de-Sá P (2012) Role of ecto-NTPDases on UDP-sensitive $\mathrm{P}_{2} \mathrm{Y}_{6}$ receptor activation during osteogenic differentiation of primary bone marrow stromal cells from postmenopausal women. J Cell Physiol 227:2694-2709

292. Zippel N, Limbach CA, Ratajski N, Urban C, Luparello C, Pansky A, Kassack MU, Tobiasch E (2012) Purinergic receptors influence the differentiation of human mesenchymal stem cells. Stem Cells Dev 21:884-900

293. Ferrari D, Gulinelli S, Salvestrini V, Lucchetti G, Zini R, Manfredini R, Caione L, Piacibello W, Ciciarello M, Rossi L, Idzko M, Ferrari S, Di Virgilio F, Lemoli RM (2011) Purinergic stimulation of human mesenchymal stem cells potentiates their chemotactic response to CXCL12 and increases the homing capacity and production of proinflammatory cytokines. Exp Hematol 39(360-74):374

294. Mohamadnejad M, Sohail MA, Watanabe A, Krause DS, Swenson ES, Mehal WZ (2010) Adenosine inhibits chemotaxis and induces hepatocyte-specific genes in bone marrow mesenchymal stem cells. Hepatology 51:963-973

295. Leong WS, Russell RG, Caswell AM (1990) Extracellular ATP stimulates resorption of bovine nasal cartilage. Biochem Soc Trans 18:951-952

296. Caswell AM, Leong WS, Russell RG (1991) Evidence for the presence of P2-purinoceptors at the surface of human articular chondrocytes in monolayer culture. Biochim Biophys Acta 1074:151-158

297. Caswell AM, Leong WS, Russell RG (1992) Interleukin-1 $\beta$ enhances the response of human articular chondrocytes to extracellular ATP. Biochim Biophys Acta 1137:52-58

298. Kaplan AD, Kilkenny DM, Hill DJ, Dixon SJ (1996) Extracellular nucleotides act through $\mathrm{P}_{2 \mathrm{U}}$ purinoceptors to elevate $\left[\mathrm{Ca}^{2+}\right]_{\mathrm{i}}$ and enhance basic fibroblast growth factor-induced proliferation in sheep chondrocytes. Endocrinology 137:4757-4766

299. Koolpe M, Benton HP (1997) Calcium-mobilizing purine receptors on the surface of mammalian articular chondrocytes. J Orthop Res 15:204-212

300. Koolpe M, Pearson D, Benton HP (1999) Expression of both $P_{1}$ and $\mathrm{P}_{2}$ purine receptor genes by human articular chondrocytes and profile of ligand-mediated prostaglandin $\mathrm{E}_{2}$ release. Arthritis Rheum 42:258-267

301. Kudirka JC, Panupinthu N, Tesseyman MA, Dixon SJ, Bernier SM (2007) P2Y nucleotide receptor signaling through MAPK/ERK is regulated by extracellular matrix: involvement of $\beta 3$ integrins. $J$ Cell Physiol 213:54-64

302. Knight MM, McGlashan SR, Garcia M, Jensen CG, Poole CA (2009) Articular chondrocytes express connexin 43 hemichannels and $\mathrm{P} 2$ receptors - a putative mechanoreceptor complex involving the primary cilium? J Anat 214:275-283

303. Varani K, De Mattei M, Vincenzi F, Tosi A, Gessi S, Merighi S, Pellati A, Masieri F, Ongaro A, Borea PA (2008) Pharmacological characterization of $\mathrm{P} 2 \mathrm{X} 1$ and $\mathrm{P} 2 \mathrm{X} 3$ purinergic receptors in bovine chondrocytes. Osteoarth Cart 16:1421-1429

304. Bulman WA, Iannotti JP, Glowacki K, Bleuit J, Clark CC (1995) Serum fractions and related agonists with calcium-mobilizing activity in the bovine growth plate chondrocyte. J Orthop Res 13:220-229

305. Hung CT, Allen FD, Mansfield KD, Shapiro IM (1997) Extracellular ATP modulates $\left[\mathrm{Ca}^{2+}\right]_{\mathrm{i}}$ in retinoic acid-treated embryonic chondrocytes. Am J Physiol 272:C1611-C1617

306. Elfervig MK, Graff RD, Lee GM, Kelley SS, Sood A, Banes AJ (2001) ATP induces $\mathrm{Ca}^{2+}$ signaling in human chondrons cultured in three-dimensional agarose films. Osteoarth Cart 9:518-526
307. Kono T, Nishikori T, Kataoka H, Uchio Y, Ochi M, Enomoto K (2006) Spontaneous oscillation and mechanically induced calcium waves in chondrocytes. Cell Biochem Funct 24:103111

308. Hsu HH (1992) Further studies on ATP-mediated CA deposition by isolated matrix vesicles. Bone Miner 17:279-283

309. Ryan LM, Kurup IV, Derfus BA, Kushnaryov VM (1992) ATPinduced chondrocalcinosis. Arthritis Rheum 35:1520-1525

310. Hsu HH, Anderson HC (1996) Evidence of the presence of a specific ATPase responsible for ATP-initiated calcification by matrix vesicles isolated from cartilage and bone. J Biol Chem 271: 26383-26388

311. Meyer MP, Swann K, Burnstock G, Clarke JDW (2001) The extracellular ATP receptor, $\mathrm{cP} 2 \mathrm{Y}_{1}$, inhibits cartilage formation in micromass cultures of chick limb mesenchyme. Dev Dyn 222: 494-505

312. Brown CJ, Caswell AM, Rahman S, Russell RG, Buttle DJ (1997) Proteoglycan breakdown from bovine nasal cartilage is increased, and from articular cartilage is decreased, by extracellular ATP. Biochim Biophys Acta 1362:208-220

313. Berenbaum F, Humbert L, Bereziat G, Thirion S (2003) Concomitant recruitment of ERK1/2 and p38 MAPK signalling pathway is required for activation of cytoplasmic phospholipase $A_{2}$ via ATP in articular chondrocytes. J Biol Chem 278:13680 13687

314. Croucher LJ, Crawford A, Hatton PV, Russell RG, Buttle DJ (2000) Extracellular ATP and UTP stimulate cartilage proteoglycan and collagen accumulation in bovine articular chondrocyte pellet cultures. Biochim Biophys Acta 1502:297-306

315. McVey GF, Crawford A, Smith TW, Buttle DJ (2006) Nucleotide triphosphates enhance collagen II and proteoglycan levels in cartilage without stimulating mRNA levels: potential for purinergic inhibition of matrix degradation pathways? Int J Exp Pathol 87:A37-A38

316. Chowdhury TT, Knight MM (2006) Purinergic pathway suppresses the release of $\mathrm{NO}$ and stimulates proteoglycan synthesis in chondrocyte/agarose constructs subjected to dynamic compression. J Cell Physiol 209:845-853

317. Pingguan-Murphy B, El-Azzeh M, Bader DL, Knight MM (2006) Cyclic compression of chondrocytes modulates a purinergic calcium signalling pathway in a strain rate- and frequency-dependent manner. J Cell Physiol 209:389-397

318. Leong WS, Russell RG, Caswell AM (1993) Induction of enhanced responsiveness of human articular chondrocytes to extracellular ATP by tumour necrosis factor-alpha. Clin Sci (Lond) 85:569-575

319. Leong WS, Russell RG, Caswell AM (1994) Stimulation of cartilage resorption by extracellular ATP acting at $\mathrm{P}_{2}$-purinoceptors. Biochim Biophys Acta 1201:298-304

320. Fodor J, Matta C, Juhász T, Oláh T, Gönczi M, Szíjgyártó Z, Gergely P, Csernoch L, Zákány R (2009) Ionotropic purinergic receptor $\mathrm{P}_{2} \mathrm{X}_{4}$ is involved in the regulation of chondrogenesis in chicken micromass cell cultures. Cell Calcium 45:421-430

321. Kwon HJ (2012) Extracellular ATP signaling via P2X $\mathrm{X}_{4}$ receptor and cAMP/PKA signaling mediate ATP oscillations essential for prechondrogenic condensation. J Endocrinol 214:337-348

322. Kwon HJ (2013) ATP oscillations mediate inductive action of FGF and Shh signalling on prechondrogenic condensation. Cell Biochem Funct 31:75-81

323. Kumahashi N, Ochi M, Kataoka H, Uchio Y, Kakimaru H, Sugawara K, Enomoto K (2004) Involvement of ATP, increase of intracellular calcium and the early expression of $c$-fos in the repair of rat fetal articular cartilage. Cell Tissue Res 317:117-128

324. Waldman SD, Usprech J, Flynn LE, Khan AA (2010) Harnessing the purinergic receptor pathway to develop functional engineered cartilage constructs. Osteoarth Cart 18:864-872 
325. Graff RD, Lazarowski ER, Banes AJ, Lee GM (2000) ATP release by mechanically loaded porcine chondrons in pellet culture. Arthritis Rheum 43:1571-1579

326. Graff RD, Picher M, Lee GM (2003) Extracellular nucleotides, cartilage stress, and calcium crystal formation. Curr Opin Rheumatol 15:315-320

327. Mason HS, Wright MO, Hall AC, Macdonald AG (1998) The effect of hypotonically induced stretch on the ion channel activity of cultured human articular chondrocytes. J Physiol 507:20P

328. Yellowley CE, Jacobs CR, Donahue HJ (1999) Mechanisms contributing to fluid-flow-induced $\mathrm{Ca}^{2+}$ mobilization in articular chondrocytes. J Cell Physiol 180:402-408

329. Millward-Sadler SJ, Wright MO, Flatman PW, Salter DM (2004) ATP in the mechanotransduction pathway of normal human chondrocytes. Biorheology 41:567-575

330. Dillon JP, Vindigni G, Collins J, Wilson PJ, Ranganath LR, Milner PI, Gallagher JA (2013) ATP-stimulated ATP release and metabolic acid production-regulating life and death decisions in articular chondrocytes. Osteoarth Cart 21:S111

331. Wann AK, Zuo N, Haycraft CJ, Jensen CG, Poole CA, McGlashan SR, Knight MM (2012) Primary cilia mediate mechanotransduction through control of ATP-induced $\mathrm{Ca}^{2+}$ signaling in compressed chondrocytes. FASEB J 26:1663-1671

332. Garcia M, Knight MM (2010) Cyclic loading opens hemichannels to release ATP as part of a chondrocyte mechanotransduction pathway. J Orthop Res 28:510-515

333. Iwamoto $\mathrm{T}$, Nakamura $\mathrm{T}$, Doyle A, Ishikawa $\mathrm{M}$, de Vega $\mathrm{S}$, Fukumoto S, Yamada Y (2010) Pannexin 3 regulates intracellular ATP/cAMP levels and promotes chondrocyte differentiation. J Biol Chem 285:18948-18958

334. Kanabe S, Hsu HH, Cecil RN, Anderson HC (1983) Electron microscopic localization of adenosine triphosphate (ATP)-hydrolyzing activity in isolated matrix vesicles and reconstituted vesicles from calf cartilage. J Histochem Cytochem 31:462-470

335. Rosenthal AK, Hempel D, Kurup IV, Masuda I, Ryan LM (2010) Purine receptors modulate chondrocyte extracellular inorganic pyrophosphate production. Osteoarth Cart 18:1496-1501

336. Yamakawa H (1999) Induction of chondrocyte apoptosis by adenosine. Ehime Med J 18:220-232

337. Tesch AM, MacDonald MH, Kollias-Baker C, Benton HP (2002) Chondrocytes respond to adenosine via $\mathrm{A}_{2}$ receptors and activity is potentiated by an adenosine deaminase inhibitor and a phosphodiesterase inhibitor. Osteoarth Cart 10:34-43

338. Varani K, De Mattei M, Vincenzi F, Gessi S, Merighi S, Pellati A, Ongaro A, Caruso A, Cadossi R, Borea PA (2008) Characterization of adenosine receptors in bovine chondrocytes and fibroblast-like synoviocytes exposed to low frequency low energy pulsed electromagnetic fields. Osteoarth Cart 16:292-304

339. Campo GM, Avenoso A, D'Ascola A, Scuruchi M, Prestipino V, Nastasi G, Calatroni A, Campo S (2012) Adenosine $A_{2 A}$ receptor activation and hyaluronan fragment inhibition reduce inflammation in mouse articular chondrocytes stimulated with interleukin-1 $\beta$. FEBS J 279:2120-2133

340. Luckprom P, Wongkhantee S, Yongchaitrakul T, Pavasant P (2010) Adenosine triphosphate stimulates RANKL expression through $\mathrm{P} 2 \mathrm{Y}_{1}$ receptor-cyclo-oxygenase-dependent pathway in human periodontal ligament cells. J Periodontal Res 45:404-411

341. Wongkhantee S, Yongchaitrakul T, Pavasant P (2007) Mechanical stress induces osteopontin expression in human periodontal ligament cells through rho kinase. J Periodontol 78:1113-1119

342. Pavasant P, Yongchaitrakul T (2001) Role of mechanical stress on the function of periodontal ligament cells. Periodontol 56:154-165

343. Luckprom P, Kanjanamekanant K, Pavasant P (2011) Role of connexin 43 hemichannels in mechanical stress-induced ATP release in human periodontal ligament cells. J Periodontal Res 46:607-615
344. Kanjanamekanant K, Luckprom P, Pavasant P (2013) Mechanical stress-induced interleukin-1beta expression through adenosine triphosphate/P2X7 receptor activation in human periodontal ligament cells. J Periodontal Res 48:169-176

345. Franckel E, Sood A, Kenamond C, Yang X, Faber J, Boitano S, Bynum D, Yang X, Sanderson M, Barnes A (1997) Human tendon cells express purinergic receptors temporally blocked by ATP in a mechanical load response. Mol Biol Cell 8:416a

346. Tsuzaki M, Bynum D, Almekinders L, Yang X, Faber J, Banes AJ (2003) ATP modulates load-inducible IL-1 $\beta$, COX 2, and MMP-3 gene expression in human tendon cells. J Cell Biochem 89:556-562

347. Tsuzaki M, Bynum D, Almekinders L, Faber J, Banes AJ (2005) Mechanical loading stimulates ecto-ATPase activity in human tendon cells. J Cell Biochem 96:117-125

348. Kindig AE, Hayes SG, Hanna RL, Kaufman MP (2006) P2 antagonist PPADS attenuates responses of thin fiber afferents to static contraction and tendon stretch. Am J Physiol Heart Circ Physiol 290:H1214-H1219

349. Yu KT, Gould MK (1978) Permissive effect of ATP on insulinstimulated sugar transport by rat soleus muscle. Am J Physiol 234:E407-E416

350. Nordenberg J, Beery E, Klein S, Kaplansky M, Frucht H, Beitner R (1987) Exogenous ATP antagonizes the actions of phospholipase $\mathrm{A}_{2}$, local anesthetics, $\mathrm{Ca}^{2+}$ ionophore $\mathrm{A} 23187$, and lithium on glucose-1,6-bisphosphate levels and the activities of phosphofructokinase and phosphoglucomutase in rat muscle. Biochem Med Metab Biol 38:278-291

351. Bertorini TE, Palmieri GM, Griffin J, Chesney C, Pifer D, Verling L, Airozo D, Fox IH (1985) Chronic allopurinol and adenine therapy in Duchenne muscular dystrophy: effects on muscle function, nucleotide degradation, and muscle ATP and ADP content. Neurology 35:61-65

352. Ferrari D, Munerati M, Melchiorri L, Hanau S, Di Virgilio F, Baricordi OR (1994) Responses to extracellular ATP of lymphoblastoid cell lines from Duchenne muscular dystrophy patients. Am J Physiol 267:C886-C892

353. Betto R, Senter L, Ceoldo S, Tarricone E, Biral D, Salviati G (1999) Ecto-ATPase activity of $\alpha$-sarcoglycan (adhalin). J Biol Chem 274:7907-7912

354. Ryten M, Yang SY, Dunn PM, Goldspink G, Burnstock G (2004) urinoceptor expression in regenerating skeletal muscle in the $\mathrm{mdx}$ mouse model of muscular dystrophy and in satellite cell cultures. FASEB J 18:1404-1406, (printed version) [Full version online (Epub, 2004, July 1, 34 pages)]

355. Yeung D, Zablocki K, Lien CF, Jiang T, Arkle S, Brutkowski W, Brown J, Lochmuller H, Simon J, Barnard EA, Górecki DC (2006) Increased susceptibility to ATP via alteration of $\mathrm{P} 2 \mathrm{X}$ receptor function in dystrophic mdx mouse muscle cells. FASEB J 20:610-620

356. Kennedy C, Leff $P(1995)$ How should $P_{2 x}$ purinoceptors be classified pharmacologically? Trends Pharmacol Sci 16:168-174

357. Bland-Ward PA, Humphrey PPA (1997) Acute nociception mediated by hindpaw $\mathrm{P} 2 \mathrm{X}$ receptor activation in the rat. Br J Pharmacol 122:365-371

358. Mork H, Ashina M, Bendtsen L, Olesen J, Jensen R (2003) Experimental muscle pain and tenderness following infusion of endogenous substances in humans. Eur J Pain 7:145-153

359. Young CN, Brutkowski W, Lien CF, Arkle S, Lochmüller H, Zablocki K, Górecki DC (2012) P2X7 purinoceptor alterations in dystrophic $m d x$ mouse muscles: relationship to pathology and potential target for treatment. J Cell Mol Med 16:1026-1037

360. Valladares D, Casas M, Figueroa R, Leyton A, Buvinic S, Jaimovich E (2011) ATP sensitivity and $\mathrm{IP}_{3}$-dependent calcium transients which regulate gene expression in adult muscle fibres are altered in Mdx mice. Biophys J 100:592a 
361. Valladares D, Almarza G, Pavez M, Jaimovich E (2012) ATP release is altered in a mouse model for Duchenne muscular dystrophy and signals for proteins that promote cell death. FASEB J 26:798.23

362. Noronha-Matos JB, Morais T, Trigo D, Timóteo MA, MagalhãesCardoso MT, Oliveira L, Correia-de-Sá P (2011) Tetanic failure due to decreased endogenous adenosine $\mathrm{A}_{2 \mathrm{~A}}$ tonus operating neuronal $\mathrm{Ca}_{\mathrm{v}} 1$ (L-type) influx in Myasthenia gravis. J Neurochem 117:797-811

363. Bazzichi L, Giannaccini G, Betti L, Fabbrini L, Schmid L, Palego L, Giacomelli C, Rossi A, Giusti L, De Feo F, Giuliano T, Mascia G, Bombardieri S, Lucacchini A (2008) ATP, calcium and magnesium levels in platelets of patients with primary fibromyalgia. Clin Biochem 41:1084-1090

364. Chidsey-Frink KL, Qi H, Crawford DT, Simmons HA, Audoly LP, Gabel CA, Thompson DD, Ke H (2001) Decreased cancellous and cortical bone mass in female mice lacking the $\mathrm{P} 2 \mathrm{X} 7$ receptor. J Bone Miner Res 16:S378

365. Bours MJ, Jørgensen NR, van Helden S, van Rhijn L, Geusens P, Wesselius A, Dagnelie PC (2008) Contributors to secondary osteoporosis and metabolic bone diseases in patients presenting with a clinical fracture. Purinergic Signal 4:S171

366. Agrawal A, Buckley KA, Bowers K, Furber M, Gallagher JA, Gartland A (2010) The effects of P2X7 receptor antagonists on the formation and function of human osteoclasts in vitro. Purinergic Signal 6:307-315

367. Jørgensen NR, Boeynaems JM, Di Virgilio F (2011) European meeting "P2 receptors: new targets for the treatment of osteoporosis". Purinergic Signal 7:275-276

368. Wesselius A, Bours MJ, Jørgensen NR, Wiley J, Gu B, van Helden S, van Rhijn L, Dagnelie PC (2013) Non-synonymous polymorphisms in the $P 2 R X_{4}$ are related to bone mineral density and osteoporosis risk in a cohort of Dutch fracture patients. Purinergic Signal 9:123-130

369. McPhee MD, Whiting SJ (1989) The effect of adenosine and adenosine analogues on methylxanthine-induced hypercalciuria in the rat. Can J Physiol Pharmacol 67:1278-1282

370. Kara FM, Doty SB, Boskey A, Fredholm BB, Cronstein BN (2007) Adenosine and osteoporosis: adenosine $\mathrm{A}_{1}$ receptor blockade reverses bone loss in ovariectomized mice and deletion of adenosine $\mathrm{A}_{2 \mathrm{~A}}$ receptors leads to diminished bone density. J Bone Min Res 22:S36

371. Kara FM, Axelrod M, Sloane J, Doty SB, Boskey A, Cronstein BN (2008) Adenosine and osteoporosis: adenosine $\mathrm{A}_{2 \mathrm{~A}}$ and $\mathrm{A}_{2 \mathrm{~B}}$ receptor blockade or deletion leads to diminished bone density. Presented at the American College of Rheumatology Scientific Meeting, San Francisco, October 24-29, 2008

372. Gharibi B, Ham J, Evans BA (2010) Adenosine A2b receptors induce osteoblastogenesis whereas A1 receptors induce adipogenesis. Bone 46:S48-S49

373. Rayalam S, Yang JY, la-Fera MA, Baile CA (2011) Novel molecular targets for prevention of obesity and osteoporosis. J Nutr Biochem 22:1099-1104

374. Niikura K (2006) Comparative analysis of the effects of a novel vacuolar adenosine 5'-triphosphatase inhibitor, FR202126, and doxycycline on bone loss caused by experimental periodontitis in rats. J Periodontol 77:1211-1216

375. Mönkkönen H, Auriola S, Lehenkari P, Kellinsalmi M, Hassinen IE, Vepsäläinen J, Mönkkönen J (2006) A new endogenous ATP analog (ApppI) inhibits the mitochondrial adenine nucleotide translocase (ANT) and is responsible for the apoptosis induced by nitrogencontaining bisphosphonates. Br J Pharmacol 147:437-445

376. Hong KC, Cruess RL (1978) Changes in organic matrix of bone and of bone and blood ATP in rats fed rachitogenic diets. Calcif Tissue Res 25:241-244
377. Sawada T, Kishiya M, Kanemaru K, Seya K, Yokoyama T, Ueyama K, Motomura S, Toh S, Furukawa K (2008) Possible role of extracellular nucleotides in ectopic ossification of human spinal ligaments. J Pharmacol Sci 106:152-161

378. Tanaka S, Kudo H, Asari T, Ono A, Motomura S, Toh S, Furukawa $\mathrm{K}$ (2011) P2Y1 transient overexpression induced mineralization in spinal ligament cells derived from patients with ossification of the posterior longitudinal ligament of the cervical spine. Calcif Tissue Int 88:263-271

379. Herbert KE, Bhusate LL, Scott DL, Perrett D (1991) Purine metabolism in arthritis: 1 . synovial fluid adenosine concentrations are low in rheumatoid arthritis. Int J Purine Pysimidine Res 2:31-34

380. Ryan LM, Rachow JW, McCarty DJ (1991) Synovial fluid ATP: a potential substrate for the production of inorganic pyrophosphate. $\mathrm{J}$ Rheumatol 18:716-720

381. Wortmann RL, Veum JA, Rachow JW (1991) Synovial fluid 5'nucleotidase activity. Relationship to other purine catabolic enzymes and to arthropathies associated with calcium crystal deposition. Arthritis Rheum 34:1014-1020

382. Loredo GA, Benton HP (1998) ATP and UTP activate calcium-mobilizing P2U-like receptors and act synergistically with interleukin-1 to stimulate prostaglandin $\mathrm{E}_{2}$ release from human rheumatoid synovial cells. Arthritis Rheum 41:246-255

383. Al-Shukaili A, Al-Kaabi J, Hassan B (2008) A comparative study of interleukin- $1 \beta$ production and $\mathrm{P} 2 \mathrm{X}_{7}$ expression after Atp stimulation by peripheral blood mononuclear cells isolated from rheumatoid arthritis patients and normal healthy controls. Inflammation 31:84-90

384. Portales-Cervantes L, Niño-Moreno P, Doníz-Padilla L, BarandaCandido L, García-Hernández M, Salgado-Bustamante M, González-Amaro R, Portales-Pérez D (2010) Expression and function of the $\mathrm{P}_{2} \mathrm{X}_{7}$ purinergic receptor in patients with systemic lupus erythematosus and rheumatoid arthritis. Hum Immunol 71:818-825

385. Portales-Cervantes L, Niño-Moreno P, Salgado-Bustamante M, García-Hernández MH, Baranda-Candido L, Reynaga-Hernández E, Barajas-López C, González-Amaro R, Portales-Pérez DP (2012) The His155Tyr $(489 \mathrm{C}>\mathrm{T})$ single nucleotide polymorphism of $P 2 R X 7$ gene confers an enhanced function of P2X7 receptor in immune cells from patients with rheumatoid arthritis. Cell Immunol 276:168-175

386. Caporali F, Capecchi PL, Gamberucci A, Lazzerini PE, Pompella G, Natale M, Lorenzini S, Selvi E, Galeazzi M, Laghi PF (2008) Human rheumatoid synoviocytes express functional $\mathrm{P}_{2} \mathrm{X}_{7}$ receptors. J Mol Med (Berl) 86:937-949

387. Gavala ML, Hill LM, Lenertz LY, Karta MR, Bertics PJ (2010) Activation of the transcription factor FosB/activating protein-1 (AP1 ) is a prominent downstream signal of the extracellular nucleotide receptor P2RX7 in monocytic and osteoblastic cells. J Biol Chem 285:34288-34298

388. Labasi JM, Petrushova N, Donovan C, McCurdy S, Lira P, Payette MM, Brissette W, Wicks JR, Audoly L, Gabel CA (2002) Absence of the P2X7 receptor alters leukocyte function and attenuates an inflammatory response. J Immunol 168:6436-6445

389. Ardissone V, Radaelli E, Zaratin P, Ardizzone M, Ladel C, Gattorno M, Martini A, Grassi F, Traggiai E (2011) Pharmacologic P2X purinergic receptor antagonism in the treatment of collageninduced arthritis. Arthritis Rheum 63:3323-3332

390. Keystone EC, Wang MM, Layton M, Hollis S, McInnes IB (2012) Clinical evaluation of the efficacy of the $\mathrm{P} 2 \mathrm{X}_{7}$ purinergic receptor antagonist AZD9056 on the signs and symptoms of rheumatoid arthritis in patients with active disease despite treatment with methotrexate or sulphasalazine. Ann Rheum Dis 71:1630-1635

391. Beswick PJ, Billinton A, Chambers LJ, Dean DK, Fonfria E, Gleave RJ, Medhurst SJ, Michel AD, Moses AP, Patel S, Roman SA, Roomans S, Senger S, Stevens AJ, Walter DS (2010) Structure-activity 
relationships and in vivo activity of (1H-pyrazol-4-yl)acetamide antagonists of the $\mathrm{P} 2 \mathrm{X}_{7}$ receptor. Bioorg Med Chem Lett 20:4653-4656

392. Bours MJ, Peeters RH, Landewé RB, Dagnelie PC (2008) ATP infusion therapy in patient with rheumatoid arthritis: design of a multicentre double-blind placebo-controlled RCT. Purinergic Signal 4:S180

393. Bours MJ, Peeters RH, Landewé RB, Beijer S, Arts IC, Dagnelie PC (2010) Adenosine 5'-triphosphate infusions reduced disease activity and inflammation in a patient with active rheumatoid arthritis. Rheumatology (Oxford) 49:2223-2225

394. Mac Mullan PA, Peace AJ, Madigan AM, Tedesco AF, Kenny D, McCarthy GM (2010) Platelet hyper-reactivity in active inflammatory arthritis is unique to the adenosine diphosphate pathway: a novel finding and potential therapeutic target. Rheumatology (Oxford) 49:240-245

395. Straub RH, Rauch L, Fassold A, Lowin T, Pongratz G (2008) Neuronally released sympathetic neurotransmitters stimulate splenic interferon- $\gamma$ secretion from T cells in early type II collagen-induced arthritis. Arthritis Rheum 58:3450-3460

396. Dowd E, McQueen DS, Chessell IP, Humphrey PP (1998) P2X receptor-mediated excitation of nociceptive afferents in the normal and arthritic rat knee joint. Br J Pharmacol 125:341-346

397. Ishikawa T, Miyagi M, Ohtori S, Aoki Y, Ozawa T, Doya H, Saito T, Moriya H, Takahashi K (2005) Characteristics of sensory DRG neurons innervating the lumbar facet joints in rats. Eur Spine J 14:559-564

398. Averill S, Inglis JJ, King VR, Thompson SW, Cafferty WB, Shortland PJ, Hunt SP, Kidd BL, Priestley JV (2008) Reg-2 expression in dorsal root ganglion neurons after adjuvant-induced monoarthritis. Neuroscience 155:1227-1236

399. Shinoda M, Ozaki N, Asai H, Nagamine K, Sugiura Y (2005) Changes in $\mathrm{P} 2 \mathrm{X} 3$ receptor expression in the trigeminal ganglion following monoarthritis of the temporomandibular joint in rats. Pain 116:42-51

400. Burnstock G (2008) Non-synaptic transmission at autonomic neuroeffector junctions. Neurochem Int 52:14-25

401. Green PG, Luo J, Heller P, Levine JD (1993) Modulation of bradykinin-induced plasma extravasation in the rat knee joint by sympathetic co-transmitters. Neuroscience 52:451-458

402. Levine JD, Fye K, Heller P, Basbaum AI, Whiting-O'Keefe Q (1986) Clinical response to regional intravenous guanethidine in patients with rheumatoid arthritis. J Rheumatol 13:1040-1043

403. Pettersson T, Klockars M, Weber TH, von Essen R (1988) Adenosine deaminase activity in joint effusions. Scand $\mathrm{J}$ Rheumatol 17:365-369

404. Yuksel H, Akoglu TF (1988) Serum and synovial fluid adenosine deaminase activity in patients with rheumatoid arthritis, osteoarthritis, and reactive arthritis. Ann Rheum Dis 47:492-495

405. Nakamachi Y, Koshiba M, Nakazawa T, Hatachi S, Saura R, Kurosaka M, Kusaka H, Kumagai S (2003) Specific increase in enzymatic activity of adenosine deaminase 1 in rheumatoid synovial fibroblasts. Arthritis Rheum 48:668-674

406. Zamani B, Jamali R, Jamali A (2012) Serum adenosine deaminase may predict disease activity in rheumatoid arthritis. Rheumatol Int 32:1967-1975

407. Akimoto M, Yunoue S, Otsubo H, Yoshitama T, Kodama K, Matsushita K, Suruga Y, Kozako T, Toji S, Hashimoto S, Uozumi K, Matsuda T, Arima N (2013) Assessment of peripheral blood $\mathrm{CD} 4+$ adenosine triphosphate activity in patients with rheumatoid arthritis. Mod Rheumatol 23:19-27

408. Masahiro K, Nakamachi Y, Kosaka H, Nakazawa T, Tsuji G, Kumagai S (2002) 2-Chloroadenosine but adenosine induced apoptosis in rheumatoid fibroblasts independently of adenosine receptor signalling. Drug Dev Res 56:74

409. Masahiro K, Nakamachi Y, Kosaka H, Nakazawa T, Tsuji G, Kumagai S (2003) Modification of cytokine milieu in rheumatoid arthritis by signalling through A2A adenosine receptors. FASEB J 17:C69

410. Forrest CM, Harman G, McMillan RB, Stoy N, Stone TW, Darlington LG (2005) Modulation of cytokine release by purine receptors in patients with rheumatoid arthritis. Clin Exp Rheumatol 23:89-92

411. Forrest CM, Stoy N, Stone TW, Harman G, Mackay GM, Oxford L, Darlington LG (2006) Adenosine and cytokine levels following treatment of rheumatoid arthritis with dipyridamole. Rheumatol Int 27:11-17

412. Madi L, Cohen S, Ochayin A, Bar-Yehuda S, Barer F, Fishman P (2007) Overexpression of A3 adenosine receptor in peripheral blood mononuclear cells in rheumatoid arthritis: involvement of nuclear factor- $\mathrm{KB}$ in mediating receptor level. J Rheumatol 34:20-26

413. Stamp LK, Hazlett J, Roberts RL, Frampton C, Highton J, Hessian PA (2012) Adenosine receptor expression in rheumatoid synovium: a basis for methotrexate action. Arthritis Res Ther 14:R138

414. Varani K, Massara A, Vincenzi F, Tosi A, Padovan M, Trotta F, Borea PA (2009) Normalization of A2A and A3 adenosine receptor up-regulation in rheumatoid arthritis patients by treatment with antitumor necrosis factor alpha but not methotrexate. Arthritis Rheum 60:2880-2891

415. Boyle DL, Moore J, Yang L, Sorkin LS, Firestein GS (2002) Spinal adenosine receptor activation inhibits inflammation and joint destruction in rat adjuvant-induced arthritis. Arthritis Rheum 46:3076-3082

416. Sorkin LS, Maruyama K, Boyle DL, Yang L, Marsala M, Firestein GS (2003) Spinal adenosine agonist reduces c-fos and astrocyte activation in dorsal horn of rats with adjuvant-induced arthritis. Neurosci Lett 340:119-122

417. Rath-Wolfson L, Bar-Yehuda S, Madi L, Ochaion A, Cohen S, Zabutti A, Fishman P (2006) IB-MECA, an $\mathrm{A}_{3}$ adenosine receptor agonist prevents bone resorption in rats with adjuvant induced arthritis. Clin Exp Rheumatol 24:400-406

418. Green PG, Basbaum AI, Helms C, Levine JD (1991) Purinergic regulation of bradykinin-induced plasma extravasation and adjuvant-induced arthritis in the rat. Proc Natl Acad Sci USA $88: 4162-4165$

419. Ochaion A, Bar-Yehuda S, Cohen S, Amital H, Jacobson KA, Joshi BV, Gao ZG, Barer F, Patoka R, Del Valle L, Perez-Liz G, Fishman $\mathrm{P}$ (2008) The A3 adenosine receptor agonist CF502 inhibits the $\mathrm{PI} 3 \mathrm{~K}, \mathrm{PKB} / \mathrm{Akt}$ and NF- signaling pathway in synoviocytes from rheumatoid arthritis patients and in adjuvant-induced arthritis rats. Biochem Pharmacol 76:482-494

420. Kosaka H, Koshiba M, Nakazawa T, Tsuji G, Saegusa J, Kanagawa S, Saura R, Kurosaka M, Yoshino S, Kumagai S (2003) Inhibition of the nucleoside transporter inhibits disease progression in the rat adjuvant-induced arthritis model. Drug Dev Res 58:479-485

421. Baharav E, Dubrosin A, Fishman P, Bar-Yehuda S, Halpren M, Weinberger A (2002) Suppression of experimental zymosaninduced arthritis by intraperitoneal administration of adenosine. Drug Dev Res 57:182-186

422. Bar-Yehuda S, Silverman MH, Kerns WD, Ochaion A, Cohen S, Fishman P (2007) The anti-inflammatory effect of $A_{3}$ adenosine receptor agonists: a novel targeted therapy for rheumatoid arthritis. Expert Opin Investig Drugs 16:1601-1613

423. Fishman P, Ochaion A, Cohen S, Patoka R, Barer F, Bar-Yehuda S (2008) The anti-inflammatory effect of A3 adenosine receptor agonists: a novel target therapy for rheumatoid arthritis. Purinergic Signal 4:S60

424. Silverman MH, Strand V, Markovits D, Nahir M, Reitblat T, Molad Y, Rosner I, Rozenbaum M, Mader R, Adawi M, Caspi D, Tishler M, Langevitz P, Rubinow A, Friedman J, Green L, Tanay A, Ochaion A, Cohen S, Kerns WD, Cohn I, Fishman-Furman S, Farbstein M, Yehuda SB, Fishman P (2008) Clinical evidence for utilization of the $\mathrm{A}_{3}$ adenosine receptor as a target to treat 
rheumatoid arthritis: data from a phase II clinical trial. J Rheumatol $35: 41-48$

425. Mazzon E, Esposito E, Impellizzeri D, Di Paola R, Melani A, Bramanti P, Pedata F, Cuzzocrea S (2011) CGS 21680, an agonist of the adenosine (A2A) receptor, reduces progression of murine type II collagen-induced arthritis. J Rheumatol 38:21192129

426. Flögel U, Burghoff S, van Lent PL, Temme S, Galbarz L, Ding Z, El-Tayeb A, Huels S, Bönner F, Borg N, Jacoby C, Müller CE, van den Berg WB, Schrader J (2012) Selective activation of adenosine $\mathrm{A}_{2 \mathrm{~A}}$ receptors on immune cells by a CD73-dependent prodrug suppresses joint inflammation in experimental rheumatoid arthritis. Sci Transl Med 4:146ra108

427. Schrader J, Flögel U, Burghoff S, Temme S, Müller CE, El-Tayeb A, van Lent P, Huels S, Bönner F, Borg N, Galbarz L (2012) The anti-inflammatory activity of a phosphorylated adenosine $\mathrm{A}_{2 \mathrm{~A}}$ receptor agonist (prodrug) in collagen-induced arthritis. Purinergic Signal 8:121

428. Vincenzi F, Padovan M, Targa M, Corciulo C, Giacuzzo S, Merighi S, Gessi S, Govoni M, Borea PA, Varani K (2013) $\mathrm{A}_{2 \mathrm{~A}}$ adenosine receptors are differentially modulated by pharmacological treatments in rheumatoid arthritis patients and their stimulation ameliorates adjuvant-induced arthritis in rats. PLoS One 8:e54195

429. Ralph JA, McEvoy AN, Kane D, Bresnihan B, FitzGerald O, Murphy EP (2005) Modulation of orphan nuclear receptor NURR1 expression by methotrexate in human inflammatory joint disease involves adenosine A2A receptor-mediated responses. J Immunol 175:555-565

430. Teramachi J, Kukita A, Li YJ, Ushijima Y, Ohkuma H, Wada N, Watanabe T, Nakamura S, Kukita T (2011) Adenosine abolishes MTX-induced suppression of osteoclastogenesis and inflammatory bone destruction in adjuvant-induced arthritis. Lab Invest 91:719731

431. Dervieux T, Wessels JA, van der Straaten T, Penrod N, Moore JH, Guchelaar HJ, Kremer JM (2009) Gene-gene interactions in folate and adenosine biosynthesis pathways affect methotrexate efficacy and tolerability in rheumatoid arthritis. Pharmacogenet Genomics 19:935-944

432. Wessels JA, Kooloos WM, de Jonge R, De Vries-Bouwstra JK, Allaart CF, Linssen A, Collee G, De Sonnaville P, Lindemans J, Huizinga TW, Guchelaar HJ (2006) Relationship between genetic variants in the adenosine pathway and outcome of methotrexate treatment in patients with recent-onset rheumatoid arthritis. Arthritis Rheum 54:2830-2839

433. Erer B, Yilmaz G, Yilmaz FM, Koklu S (2009) Assessment of adenosine deaminase levels in rheumatoid arthritis patients receiving anti-TNF-alpha therapy. Rheumatol Int 29:651-654

434. Zakeri Z, Izadi S, Niazi A, Bari Z, Zendeboodi S, Shakiba M, Mashhadi M, Narouie B, Ghasemi-Rad M (2012) Comparison of adenosine deaminase levels in serum and synovial fluid between patients with rheumatoid arthritis and osteoarthritis. Int J Clin Exp Med 5:195-200

435. Johnson K, Svensson CI, Etten DV, Ghosh SS, Murphy AN, Powell HC, Terkeltaub R (2004) Mediation of spontaneous knee osteoarthritis by progressive chondrocyte ATP depletion in Hartley guinea pigs. Arthritis Rheum 50:1216-1225

436. Costello JC, Rosenthal AK, Kurup IV, Masuda I, Medhora M, Ryan LM (2011) Parallel regulation of extracellular ATP and inorganic pyrophosphate: roles of growth factors, transduction modulators, and ANK. Connect Tissue Res 52:139-146

437. Kumahashi N, Naitou K, Nishi H, Oae K, Watanabe Y, Kuwata S, Ochi M, Ikeda M, Uchio Y (2011) Correlation of changes in pain intensity with synovial fluid adenosine triphosphate levels after treatment of patients with osteoarthritis of the knee with highmolecular-weight hyaluronic acid. Knee 18:160-164
438. Mrazek F, Gallo J, Stahelova A, Petrek M (2010) Functional variants of the $P 2 R X 7$ gene, aseptic osteolysis, and revision of the total hip arthroplasty: a preliminary study. Hum Immunol 71:201-205

439. Dowd E, McQueen DS, Chessell IP, Humphrey PP (1998) Adenosine A1 receptor-mediated excitation of nociceptive afferents innervating the normal and arthritic rat knee joint. $\mathrm{Br} \mathrm{J}$ Pharmacol 125:1267-1271

440. Mistry D, Chambers MG, Mason RM (2006) The role of adenosine in chondrocyte death in murine osteoarthritis and in a murine chondrocyte cell line. Osteoarth Cart 14:486-495

441. Petrov R, MacDonald MH, Tesch AM, Benton HP (2005) Inhibition of adenosine kinase attenuates interleukin-1- and lipopolysaccharideinduced alterations in articular cartilage metabolism. Osteoarth Cart 13:250-257

442. Russell JM, Stephenson GS, Yellowley CE, Benton HP (2007) Adenosine inhibition of lipopolysaccharide-induced interleukin-6 secretion by the osteoblastic cell line MG-63. Calcif Tissue Int $81: 316-326$

443. De Mattei M, Varani K, Masieri FF, Pellati A, Ongaro A, Fini M, Cadossi R, Vincenzi F, Borea PA, Caruso A (2009) Adenosine analogs and electromagnetic fields inhibit prostaglandin E2 release in bovine synovial fibroblasts. Osteoarth Cart 17:252-262

444. Ongaro A, Varani K, Masieri FF, Pellati A, Massari L, Cadossi R, Vincenzi F, Borea PA, Fini M, Caruso A, De Mattei M (2012) Electromagnetic fields (EMFs) and adenosine receptors modulate prostaglandin $\mathrm{E}(2)$ and cytokine release in human osteoarthritic synovial fibroblasts. J Cell Physiol 227:2461-2469

445. Varani K, Vincenzi F, Tosi A, Targa M, Masieri FF, Ongaro A, De Mattei M, Massari L, Borea PA (2010) Expression and functional role of adenosine receptors in regulating inflammatory responses in human synoviocytes. Br J Pharmacol 160:101-115

446. Cohen SB, Gill SS, Baer GS, Leo BM, Scheld WM, Diduch DR (2004) Reducing joint destruction due to septic arthrosis using an adenosine 2A receptor agonist. J Orthop Res 22:427-435

447. Munoz AM, Frenkel SR, Immerman I, Hadley S, Howell D, Cronstein BN (2010) Adenosine $\mathrm{A}_{2 \mathrm{~A}}$ receptor agonists: can they prevent/treat joint prosthesis loosening. Purinergic Signal 6:S159

448. Chirgwin JM, Guise TA (2007) Skeletal metastases: decreasing tumor burden by targeting the bone microenvironment. J Cell Biochem 102:1333-1342

449. Casimiro S, Guise TA, Chirgwin J (2009) The critical role of the bone microenvironment in cancer metastases. Mol Cell Endocrinol 310:71-81

450. Liu PS, Chen CY (2010) Butyl benzyl phthalate suppresses the ATP-induced cell proliferation in human osteosarcoma HOS cells. Toxicol Appl Pharmacol 244:308-314

451. Hatta Y, Aizawa S, Horikoshi A, Baba M, Horie T (1993) Selective killing of murine leukemic cells by adenosine triphosphate (ATP): a study of the value of autologous bone marrow transplantation. Intern Med 32:768-772

452. Uluçkan Ö, Eagleton MC, Floyd DH, Morgan EA, Hirbe AC, Kramer M, Dowland N, Prior JL, Piwnica-Worms D, Jeong SS, Chen R, Weilbaecher K (2008) APT102, a novel ADPase, cooperates with aspirin to disrupt bone metastasis in mice. J Cell Biochem 104:1311-1323

453. Mönkkönen H, Kuokkanen J, Holen I, Evans A, Lefley DV, Jauhiainen M, Auriola S, Mönkkönen J (2008) Bisphosphonateinduced ATP analog formation and its effect on inhibition of cancer cell growth. Anticancer Drugs 19:391-399

454. Sillero MA, de Diego A, Tavares JE, Silva JA, Pérez-Zúñiga FJ, Sillero A (2009) Synthesis of ATP derivatives of compounds of the mevalonate pathway (isopentenyl di- and triphosphate; geranyl diand triphosphate, farnesyl di- and triphosphate, and dimethylallyl diphosphate) catalyzed by T4 RNA ligase, T4 DNA ligase and other ligases Potential relationship with the effect of bisphosphonates on osteoclasts. Biochem Pharmacol 78:335-343 
455. Park HC, Seong J, An JH, Kim J, Kim UJ, Lee BW (2005) Alteration of cancer pain-related signals by radiation: proteomic analysis in an animal model with cancer bone invasion. Int J Radiat Oncol Biol Phys 61:1523-1534

456. Gilchrist LS, Cain DM, Harding-Rose C, Kov AN, WendelschaferCrabb G, Kennedy WR, Simone DA (2005) Re-organization of $\mathrm{P}_{2} \mathrm{X}_{3}$ receptor localization on epidermal nerve fibers in a murine model of cancer pain. Brain Res 1044:197-205

457. Kaan TK, Yip PK, Patel S, Davies M, Marchand F, Cockayne DA, Nunn PA, Dickenson AH, Ford AP, Zhong Y, Malcangio M, McMahon SB (2010) Systemic blockade of $\mathrm{P} 2 \mathrm{X}_{3}$ and $\mathrm{P} 2 \mathrm{X}_{2 / 3}$ receptors attenuates bone cancer pain behaviour in rats. Brain 133:2549-2564

458. Hansen RR, Nasser A, Falk S, Baldvinsson SB, Ohlsson PH, Bahl JM, Jarvis MF, Ding M, Heegaard AM (2012) Chronic administration of the selective $\mathrm{P} 2 \mathrm{X} 3, \mathrm{P} 2 \mathrm{X} 2 / 3$ receptor antagonist, A-317491, transiently attenuates cancer-induced bone pain in mice. Eur $\mathrm{J}$ Pharmacol 688:27-34

459. Wu JX, Xu MY, Miao XR, Lu ZJ, Yuan XM, Li XQ, Yu WF (2012) Functional up-regulation of $\mathrm{P} 2 \mathrm{X} 3$ receptors in dorsal root ganglion in a rat model of bone cancer pain. Eur $\mathrm{J}$ Pain 16:1378-1388

460. Hansen RR, Nielsen CK, Nasser A, Thomsen SI, Eghorn LF, Pham Y, Schulenburg C, Syberg S, Ding M, Stojilkovic SS, Jorgensen NR, Heegaard AM (2011) P2X7 receptor-deficient mice are susceptible to bone cancer pain. Pain 152:1766-1776

461. Farrell AW, Gadeock S, Pupovac A, Wang B, Jalilian I, Ranson M, Sluyter R (2010) P2X7 receptor activation induces cell death and CD23 shedding in human RPMI 8226 multiple myeloma cells. Biochim Biophys Acta 1800:1173-1182

462. Chen J, Wang L, Zhang Y, Yang J (2012) P2Y1 purinoceptor inhibition reduces extracellular signal-regulated protein kinase $1 / 2$ phosphorylation in spinal cord and dorsal root ganglia: implications for cancer-induced bone pain. Acta Biochim Biophys Sin (Shanghai) 44:367-372

463. He W, Mazumder A, Cronstein BN (2012) Adenosine regulates bone metabolism via $\mathrm{A}_{1}, \mathrm{~A}_{2 \mathrm{~A}}$ and $\mathrm{A}_{2 \mathrm{~B}}$ receptors in bone marrow cells from normal and patients with multiple myeloma. Arthrit Rheumat 64:S833

464. Krett NL, Davies KM, Ayres M, Ma C, Nabhan C, Gandhi V, Rosen ST (2004) 8-amino-adenosine is a potential therapeutic agent for multiple myeloma. Mol Cancer Ther 3:1411-1420

465. Sauer AV, Mrak E, Hernandez RJ, Zacchi E, Cavani F, Casiraghi M, Grunebaum E, Roifman CM, Cervi MC, Ambrosi A, Carlucci F, Roncarolo MG, Villa A, Rubinacci A, Aiuti A (2009) ADA-deficient SCID is associated with a specific microenvironment and bone phenotype characterized by RANKL/OPG imbalance and osteoblast insufficiency. Blood 114:3216-3226

466. Huber C, Oulès B, Bertoli M, Chami M, Fradin M, Alanay Y, Al-Gazali LI, Ausems MG, Bitoun P, Cavalcanti DP, Krebs A, Le Merrer M, Mortier G, Shafeghati Y, Superti-Furga A, Robertson SP, Le Goff C, Muda AO, Paterlini-Bréchot P, Munnich A, CormierDaire V (2009) Identification of CANT1 mutations in Desbuquois dysplasia. Am J Hum Genet 85:706-710

467. Guzmán-Aránguez A, Irazu M, Yayon A, Pintor J (2007) Effect of diadenosine polyphosphates in achondroplasic chondrocytes: inhibitory effect of $\mathrm{Ap}_{4} \mathrm{~A}$ on FGF9 induced MAPK cascade. Biochem Pharmacol 74:448-456

468. Guzmán-Aránguez A, Irazu M, Yayon A, Pintor J (2008) P2Y receptors activated by diadenosine polyphosphates reestablish $\mathrm{Ca}^{2+}$ transients in achondroplasic chondrocytes. Bone 42:516-523

469. Huete F, Guzmán-Aránguez A, Ortin J, Hoyle CH, Pintor J (2011) Effects of diadenosine tetraphosphate on FGF9-induced chloride flux changes in achondroplastic chondrocytes. Purinergic Signal 7:243-249 